\title{
28. GEOCHEMISTRY OF BASALTS RECOVERED FROM THE GULF OF CALIFORNIA DURING LEG 65 OF THE DEEP SEA DRILLING PROJECT ${ }^{1}$
}

\author{
Andrew D. Saunders, Department of Geology, Bedford College, \\ Regent's Park, London NW1 4NS, United Kingdom
}

\begin{abstract}
Leg 65 of the Deep Sea Drilling Project successfully recovered basalts from four sites in the mouth of the Gulf of California, thus completing a transect begun during Leg 64 from the continental margin of Baja California to the east side of the East Pacific Rise (EPR). Sixty-three whole-rock samples from Sites 482,483 , and 485 have been analyzed by $\mathrm{X}$-ray fluorescence techniques, and a further eleven samples by instrumental neutron-activation techniques, in order to assess magma variability within and between sites. Although the major element compositions and absolute hygromagmatophile (HYG) element abundances are quite variable, all of the basalts are subalkaline tholeiites exhibiting strong more-HYG element (e.g., $\mathrm{Rb}, \mathrm{La}, \mathrm{Nb}, \mathrm{Ta})$ depletion $\left(\mathrm{La}_{\mathrm{N}} / \mathrm{Yb}_{\mathrm{N}} \sim 0.4 ; \mathrm{Nb} / \mathrm{Zr} \sim 0.02 ; \mathrm{Ba} / \mathrm{Zr} \sim 0.23 ; \mathrm{Th} / \mathrm{Hf} \sim 0.05\right.$ ). These ratios, together with $\mathrm{La} / \mathrm{Ta}$ ratios of 20 and $\mathrm{Th} / \mathrm{Ta}$ ratios of 1.25 , demonstrate that the Leg 65 basalts resemble the depleted " $\mathrm{N}$-type" ocean ridge basalts recovered from the Mid-Atlantic Ridge (MAR) at $22^{\circ} \mathrm{N}$ and other sections of the EPR. $\mathrm{Zr} / \mathrm{Ti}, \mathrm{Zr} / \mathrm{Y}$, and $\mathrm{La} / \mathrm{Yb}$ ratios increase with increasing fractionation. It is clear that the basalts recovered from Sites 482,483 , and 485 were all derived from a compositionally similar source and that the compositional differences observed between lithological units can be explained by varying degrees of open system fractional crystallization (magma mixing) in subridge magma chambers.

The basaltic rocks recovered from Site 474 near the margin of Baja California, and Sites 477,478 , and 481 in the Guaymas Basin, all drilled during Leg 64 , have consistently higher $\mathrm{Th} / \mathrm{Hf}, \mathrm{La} / \mathrm{Sm}, \mathrm{Zr} / \mathrm{Ti}$, and $\mathrm{Zr} / \mathrm{Y}$ ratios and higher absolute $\mathrm{Sr}$ contents than the Leg 65 basalts. While some of these variations may be explained by different conditions of partial melting, it is considered more likely that the mantle source underlying the Guaymas Basin is chemically distinct from that feeding the EPR at the mouth of the Gulf. These source variations probably reflect the complex tectonic setting of the Gulf of California, the magmas formed at the inception of spreading and in the central part of the Gulf containing a minor but significant component of sub-continental (calc-alkaline) material.
\end{abstract}

\section{INTRODUCTION}

Leg 65 of the Deep Sea Drilling Project (DSDP) drilled into oceanic crust at four sites in the mouth of the Gulf of California, thus successfully completing the transect from the continental margin off Baja California to the East Pacific Rise (EPR) commenced at Site 474 during Leg 64 (Fig. 1). Sites 482 and 485 were approximately twelve kilometers apart and located just to the east of the EPR, on basement less than 1 m.y. old. Drilling in eight of the holes attempted at these sites successfully recovered aphyric and sparsely phyric massive basalts and pillow basalts from a sequence of flows and (rare) sills. Preliminary shipboard petrographic and geochemical studies reveal that the flows recovered from Holes $482 \mathrm{~B}$ to $482 \mathrm{~F}$ are laterally continuous between holes and that there is a relative scarcity of pillow lavas at the site.

Site 483 was located on a topographically smooth area of ocean floor, approximately two-thirds of the distance from the East Pacific Rise to the continental margin of Baja California. The basement at this site, from magnetic anomaly data, is estimated to be $2 \mathrm{~m}$.y. old. Again, the basalt lithologies recovered from Holes 483 and 483B are very similar, indicating lateral continuity of flows. Site 484 was located on a small, strongly

\footnotetext{
${ }^{1}$ Lewis, B. T. R., Robinson, P., et al., Init. Repts. DSDP, 65: Washington (U.S. Govt. Printing Office).
}

magnetic basement high in the northern trough of the Tamayo Fracture Zone, but basement recovery was poor.

The oldest oceanic crust (3.2 m.y.) sampled on the transect was that drilled at Site 474 during Leg 64 . This site was located approximately 5 kilometers from the transition from oceanic to continental crust near the southeast tip of Baja California (Fig. 1). The drilling in Hole $474 \mathrm{~A}$ penetrated a thick sedimentary sequence, several olivine-rich sills representing off-axis magmatic activity and approximately 64 meters of pillow and massive basalts more typical of Oceanic Layer 2 .

This chapter describes the major and trace element chemistry of representative basalts from Sites 482,483 , and 485 . Within- and between-site variations will be assessed and various petrogenetic models presented to explain them. The main aim of the study, however, is to compare the geochemistry of Leg 65 basalts with (1) the geochemistry of the basalts recovered from the basement at Site 474 and (2) the geochemistry of the basalts, dolerites, and gabbros recovered from the Guaymas Basin during Leg 64 . Sites $482,483,485$, and 474 lie along the same mantle flow line and thus can potentially provide information about secular changes in mantle composition. Similar transects were made during DSDP Leg 49 (Luyendyk, Cann et al., 1979) and other legs in the North Atlantic Ocean, but Legs 64 and 65 have recovered basalts produced during the earliest stages of ocean crust formation from regions of the ocean floor normally buried beneath several kilometers of sediment. 


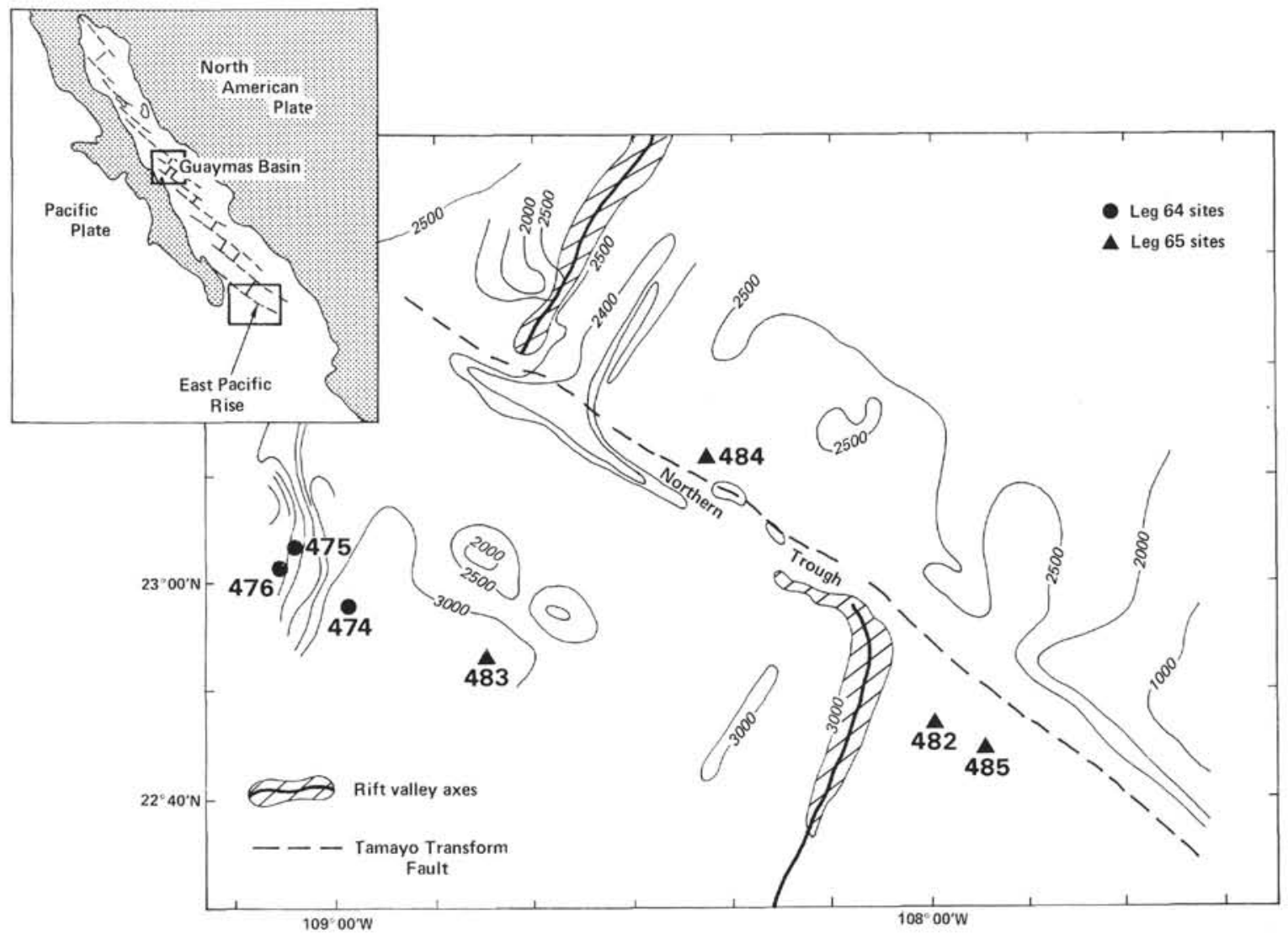

Figure 1. Map of the mouth of the Gulf of California, showing the locations of the sites occupied during Leg 65 and the location of Site 474 occupied during Leg 64 . Sites 477, 478, and 481 (not shown) were located in the Guaymas Basin (inset). (Water depths shown in $\mathrm{m}$.)

In addition to determining the composition of the mantle source at the mouth of the Gulf, comparisons will be made with mafic rocks recovered from the Guaymas Basin in the central part of the Gulf. Here, two short spreading centers are partially buried beneath sediments and the dominant lithology consists of massive sills or sill-like bodies. Detailed petrologic and geochemical descriptions of the igneous samples recovered from Sites 477, 478, and 481 in the Guaymas Basin have been presented elsewhere (Saunders et al., in press). By comparing these results with analyses of the Leg 65 basalts, a quantitative assessment can be made of any spatial chemical variations along the Gulf. Such variations may of course reflect differing processes of magma generation, or mantle heterogeneity, or both.

Saunders et al. (in press) have pointed out that the Gulf of California is neither a true back-arc basin nor simply an extension of the Pacific Basin. The Gulf opened within continental crust which until recently ( $\sim 20 \mathrm{~m}$.y. ago) was in close proximity to an active calcalkaline arc (e.g., Karig and Jensky, 1972). Basalts erupted in ensialic back-arc basins frequently have chemistries exhibiting some affinities to both calc-alkaline and ocean ridge basalts (Saunders and Tarney, 1979, Saunders, Tarney, Stern, et al., 1980; Weaver et al., 1979; Tarney et al., 1981), and indeed Saunders et al. (in press) have shown that the samples from the Guaymas
Basin have higher $\mathrm{Sr} / \mathrm{Zr}, \mathrm{La} / \mathrm{Yb}, \mathrm{Th} / \mathrm{Hf}$, and $\mathrm{Zr} / \mathrm{Ti}$ ratios than do "depleted" ocean ridge basalts. These differences will be discussed in more detail in this chapter, but it is important to realize that although the samples from the Guaymas Basin appear to be chemically distinct from the basalts presently being erupted elsewhere along the East Pacific Rise, they do exhibit overall relative depletion of the more-hygromagmatophile (HYG) elements, and were probably derived from a source resembling normal Pacific-type mantle. This is consistent with tectonic reconstructions of the Gulf region by Dickinson and Snyder (1979) which indicate that the Gulf of California and Baja California have been underlain by a "no-slab" window, and hence by implication, Pacific-type mantle, for at least the last 5 m.y.

\section{ANALYTICAL TECHNIQUES}

\section{Sample Preparation}

The samples analyzed in this study consist of mini-cores or quarter-core sections selected from the least altered sections of the core. Sample preparation techniques were identical to those described in Saunders et al. (in press).

\section{X-Ray Fluorescence Analysis}

A total of 64 whole-rock samples has been analyzed using the Philips PW1450 automatic spectrometer at the University of Birmingham; the count data were processed using Digital PDP 11-03 and ICL 1906A computers. Major and minor element analyses were determined on 
46-mm powder briquettes and representative fusion beads using a rhodium-anode X-ray tube. Trace element abundances were determined on powder briquettes using molybdenum $(\mathrm{Y}, \mathrm{Sr}, \mathrm{Rb}, \mathrm{Ga}, \mathrm{Zn}$, and $\mathrm{Ba}$ ), tungsten ( $\mathrm{Ce}, \mathrm{La}$ and $\mathrm{Nd})$, and rhodium $(\mathrm{Ni}, \mathrm{Cr}, \mathrm{Zr}$ and $\mathrm{Nb}$ ) anode X-ray tubes in order to obtain maximum sensitivity. Details of the trace element analysis using Mo and W tubes are given in Tarney et al. (1979), while those for the major and minor elements using the $\mathrm{Rh}$ tube are given in Marsh et al. (1980). Unlike previous runs, however, several trace elements were analyzed using the $\mathrm{Rh}$-anode tube. $\mathrm{Ni}\left(\mathrm{K}_{\alpha}\right)$, $\mathrm{Cr}\left(\mathrm{K}_{\alpha}\right), \mathrm{Zr}\left(\mathrm{K}_{\alpha}\right)$ and $\mathrm{Nb}\left(\mathrm{K}_{\alpha}\right)$ were measured using flow-counter ( $\mathrm{Ni}$ and $\mathrm{Cr})$ and scintillation-counter $(\mathrm{Zr}, \mathrm{Nb})$ detectors in conjunction with a $\mathrm{LiF}_{220}$ crystal to disperse the fluorescent radiation. Counts were corrected for absorption using the $\mathrm{Rh} \mathrm{K}_{\alpha}$ Compton peak ( $\mathrm{Rh} \mathrm{K}_{\alpha}+1.0^{\circ}$ $2 \theta$ ), and for $\mathrm{Cr}$ by using the $\mathrm{Fe}$ count rate. $\mathrm{Ni}$ and $\mathrm{Cr}$ have been corrected for X-ray tube contamination. A correction has not been made for the overlap of the $\mathrm{V} \mathrm{K}_{\beta}$ peak on the $\mathrm{Cr} \mathrm{K}_{\alpha}$ peak; thus the $\mathrm{Cr}$ results are high by approximately $6 \%$ of the $\mathrm{V}$ concentration. $\mathrm{Zr}$ has been corrected for the overlap of the $\mathrm{Sr} \mathrm{K}_{\beta}$ and $\mathrm{Sr} \mathrm{K}_{\beta 3}$ peaks (approximately $3 \mathrm{ppm}$ per $100 \mathrm{ppm} \mathrm{Sr}$ ).

The precision of the X-ray fluorescence analyses made at Birmingham is generally high. Unfortunately, several of the trace elements in the Leg 65 basalts have very low abundances, and although these abundances may exceed the theoretical lower level of detection (two standard deviations above the background), in fact the precision falls dramatically at low abundance levels. It is therefore more meaningful to refer to the more qualitative lower level of determination. Those elements approaching the lower level of determination include $\mathrm{Nb}(2$ $\mathrm{ppm})$ and, in some samples, $\mathrm{La}(\sim 5 \mathrm{ppm})$ and $\mathrm{Ce}(\sim 8 \mathrm{ppm})$. Analytical values below these levels should be treated with caution.

The accuracy of the analyses must be judged against international reference samples which, for many trace elements, do not cover the range of concentrations encountered in most DSDP basalts. BCR-1 data for trace elements are given in Tarney et al. (1979) and, for a wider range of materials, in Hendry (1975). The data for standard basalt BOB-1 are given in Table 1 for cross reference to the Leg 64 data in Saunders et al. (in press). A particular effort has been made to ensure that the analyses of the Leg 65 basalts are compatible with those from Leg 64.

\section{Instrumental Neutron Activation Analysis}

A total of eleven samples have been analyzed by energy-dispersive instrumental neutron activation (INA) techniques at Bedford College, University of London. Samples and standards were irradiated along with iron-foil neutron flux monitors for approximately seven days in the University of London nuclear reactor at Ascot. They were then left to cool for a period of five days prior to analysis at Bedford College in order to allow ${ }^{24} \mathrm{Na}$ to decay. ${ }^{140} \mathrm{La}$ at $1596.49 \mathrm{keV}$ was counted immediately for between $3 \times 10^{2}$ and $20 \times 10^{2}$ seconds using an Ortec high-energy Ge detector with a Northern Scientific 1024 multichannel analyzer.

The spectra of the remaining isotopes were counted on a low energy $\mathrm{Ge}-\mathrm{Li}$ detector, with the data being collected via an analog to digital converter in a Zilog Z-80 microprocessor developed by Drs I. L. Gibson, P. Taylor, and G. F. Marriner. Initially, the short-lived isotope ${ }^{153} \mathrm{Sm}$ at $103.2 \mathrm{keV}$ was counted for $20 \times 10^{2}$ seconds and then ${ }^{141} \mathrm{Ce}(145.4 \mathrm{keV}),{ }^{147} \mathrm{Nd}(91.1 \mathrm{keV}),{ }^{152} \mathrm{Eu}(121.8 \mathrm{keV}),{ }^{153} \mathrm{Gd}(97.4$ $\mathrm{keV}),{ }^{160} \mathrm{~Tb}(86.78 \mathrm{keV}),{ }^{170} \mathrm{Tm}(84.26 \mathrm{keV}),{ }^{169} \mathrm{Yb}(109.7 \mathrm{keV}),{ }^{177} \mathrm{Lu}$ $(112.97 \mathrm{keV}),{ }^{181} \mathrm{Hf}(133.0 \mathrm{keV}),{ }^{182} \mathrm{Ta}(100.0 \mathrm{keV})$, and ${ }^{232} \mathrm{Th}(98.4$ $\mathrm{keV}$ ) were counted for at least eight hours per sample.

The spectra were processed using the spectrum analysis program SAMPO. Corrections were made for half-life neutron flux variations and interfering peaks (Th on Tb, Sm on Gd, Ta on Tm) and data were standardized to a reference sample (in this case, Ailsa Craig granite) and checked using BOB-1, BCR-1, or W-1 as a second standard.

For most elements the precision is better than $2 \%$ above $10 \mathrm{ppm}$, better than $5 \%$ above $2 \mathrm{ppm}$, and better than $10 \%$ at lower levels. As with XRF analysis, the accuracy of INA analysis can only be determined by comparisons with international reference standards. Values for W-1 and BCR-1 are therefore included in Table 1. Values for W-1 obtained during the analysis of the Leg 64 samples are also given in Table 1 . In general, agreement between the two sets of analyses is good.
Table 1. Analyses of standard reference samples.

\begin{tabular}{|c|c|c|c|}
\hline Component & BOB-1 ${ }^{\text {a }}$ & BOB-1 ${ }^{b}$ & \\
\hline \multicolumn{4}{|c|}{ Major elements (wt.\%) } \\
\hline $\mathrm{SiO}_{2}$ & 50.53 & 51.2 & \\
\hline $\mathrm{TiO}_{2}$ & 1.33 & 1.29 & \\
\hline $\mathrm{Al}_{2} \mathrm{O}_{3}$ & 16.5 & 16.8 & \\
\hline $\mathrm{tFe}_{2} \mathrm{O}_{3}$ & 9.12 & 8.6 & \\
\hline $\mathrm{MnO}$ & 0.15 & 0.13 & \\
\hline $\mathrm{MgO}$ & 7.6 & 7.8 & \\
\hline $\mathrm{CaO}$ & 11.77 & 11.23 & \\
\hline $\mathrm{Na}_{2} \mathrm{O}$ & 3.0 & 3.1 & \\
\hline $\mathrm{K}_{2} \mathrm{O}$ & 0.38 & 0.37 & \\
\hline $\mathrm{P}_{2} \mathrm{O}_{5}$ & 0.13 & 0.16 & \\
\hline Total & 100.92 & 100.56 & \\
\hline \multicolumn{4}{|c|}{ Trace elements (ppm) } \\
\hline $\mathrm{Ni}$, & 107 & 106 & \\
\hline $\mathrm{Cr}^{1}$ & 236 & 240 & \\
\hline $\mathrm{Zn}$ & 62 & 60 & \\
\hline $\mathrm{Ga}$ & 19 & 18 & \\
\hline $\mathrm{Rb}$ & 4.7 & 4.6 & \\
\hline $\mathrm{Sr}_{2}$ & 199 & 199 & \\
\hline $\mathrm{Y}^{2}$ & 26 & 27 & \\
\hline $\mathrm{Zr}^{3}$ & 102 & 102 & \\
\hline $\mathrm{Nb}$ & 5 & 5 & \\
\hline $\mathrm{Ba}^{4}$ & 57 & 58 & \\
\hline $\mathrm{La}$ & 6 & 7 & \\
\hline $\mathrm{Ce}$ & 15 & 13 & \\
\hline \multirow[t]{2}{*}{$\mathrm{Nd}$} & 11 & 11 & \\
\hline & $\mathrm{W}-1^{\mathrm{c}}$ & $\mathrm{W}-1^{\mathrm{d}}$ & $\mathrm{BCR}-1^{\mathrm{C}}$ \\
\hline
\end{tabular}

Neutron activation analyses (ppm)

\begin{tabular}{lccl}
$\mathrm{La}$ & 11.4 & 10.1 & 23.7 \\
$\mathrm{Ce}$ & 22.6 & 22.6 & 50.0 \\
$\mathrm{Nd}$ & 13.8 & 13.2 & 31.3 \\
$\mathrm{Sm}$ & 3.5 & 3.34 & 6.48 \\
$\mathrm{Eu}$ & 1.2 & 1.13 & 2.11 \\
$\mathrm{Gd}$ & - & 3.58 & - \\
$\mathrm{Tb}$ & 0.63 & 0.62 & 1.10 \\
$\mathrm{Tm}$ & 0.34 & - & 0.63 \\
$\mathrm{Yb}$ & 2.09 & 2.13 & 3.49 \\
$\mathrm{Lu}$ & 0.32 & 0.31 & 0.50 \\
$\mathrm{Th}$ & 2.64 & 2.43 & 6.8 \\
$\mathrm{Ta}$ & 0.52 & 0.53 & 0.81 \\
$\mathrm{Hf}$ & 2.65 & 2.44 & 4.9 \\
\hline
\end{tabular}

a Values for standard basalt BOB-1 determined during this study.

$b$ Values for BOB-1 from Saunders et al. (in press). ( ${ }^{1}$ Not corrected for $\mathrm{V}$ interference; ${ }^{2}$ corrected for $\mathrm{Rb}$ interference; ${ }^{3}$ corrected for $\mathrm{Sr}$ interference; ${ }^{4}$ corrected for Ce interference).

c INAA values for $\mathrm{W}-1$ (this study);

d INAA values for W-1 from Saunders et al. (in press).

${ }^{e}$ INAA values for BCR-1 (this study).

\section{TRACE AND MINOR ELEMENT NOMENCLATURE}

Trace elements may be either incompatible or compatible, depending on whether their bulk crystal/liquid distribution coefficients, $D$, are significantly less than 
one or more than one, respectively. Recent studies of incompatible elements have shown that they may be conveniently grouped according to their relative incompatibility into hygromagmatophile (HYG) or more-hygromagmatophile types. As an approximate guideline, HYG elements are those with $D$ values of approximately 0.1 , and more-HYG elements are those with $D$ values significantly less than 0.01 . In oceanic basalt systems, the more-HYG elements include (in order of decreasing $D$ ) $\mathrm{Cs}, \mathrm{Rb}, \mathrm{Ba}, \mathrm{U}, \mathrm{Th}, \mathrm{K}, \mathrm{Ta}, \mathrm{Nb}, \mathrm{La}$, and $\mathrm{Ce}$, and the HYG elements include (also in order of decreasing $D$ ) $\mathrm{Sr}, \mathrm{Nd}, \mathrm{P}, \mathrm{Hf}, \mathrm{Zr}$, the heavy rare earth elements (REE), Ti, and Y (see, for example, Bougault et al., 1978; Bougault and Treuil, 1980; Wood, Tarney, Varet, et al., 1979). $D$ values may of course vary according to the PTX conditions of the system; $\mathrm{Sr}$ and $\mathrm{Eu}$, for example, can have $D$ values exceeding 1 during plagioclase fractionation.

A second grouping of trace elements, based on ionic radius and charge, is also convenient for petrogenetic discussions. Large ions, usually with low charges or with the ability to form hydration spheres, have been termed large ion lithophile or LIL elements (Saunders, Tarney, and Weaver, 1980) and include Cs, K, Rb, Ba, $\mathrm{U}, \mathrm{Th}, \mathrm{Sr}(\mathrm{La}, \mathrm{Ce})$. Several of these elements, particularly $\mathrm{Cs}, \mathrm{K}, \mathrm{Rb}, \mathrm{U}$, and $\mathrm{Sr}$, are easily mobilized during hydrothermal alteration, and it is possible that their primary values are affected by interaction with seawater (Hart, 1971; Hart et al., 1974; Mitchell and Aumento, 1977). In cases of severe alteration, the abundances of La and Ce (Ludden and Thompson, 1979) and even Th may also be affected.

Small ions with high charges belong to the high field strength or HFS group (Pearce and Norry, 1979; Saunders et al., 1980a), and include $\mathrm{Ti}, \mathrm{P}, \mathrm{Zr}, \mathrm{Hf}, \mathrm{Nb}, \mathrm{Ta}$, most of the rare earth elements, and Y. Since these elements are less susceptible to hydrothermal alteration, it is more likely that the observed values will be primary. As in the treatment of the Leg 64 analyses, therefore, emphasis will be placed on the distribution of the HFS elements rather than of the LIL elements, even though the degree of secondary alteration of the Leg 65 basalts is generally lower than that of the Leg 64 samples.

\section{SITE 482}

Site $482\left(22^{\circ} 47.34^{\prime} \mathrm{N}, 107^{\circ} 59.57^{\prime} \mathrm{W} ; 2998 \mathrm{~m}\right.$ water depth) was located in a sediment-filled valley approximately 12 kilometers east of the EPR, near the intersection of the EPR and the Tamayo Fracture Zone (Fig. 1). The estimated age of the basement at this site, $0.5 \mathrm{~m}$.y., is comparable to that drilled during Leg 64 in the Guaymas Basin (<0.4 m.y.).

Six holes were attempted at this site; four of these (482B, 482C, 482D, and 482F) successfully penetrated basement and recovered basalts. In the following discussion, only brief reference will be made to the petrography of the samples recovered from the major units, but further details may be obtained from the Site 482 report (this volume). Wherever possible, the petrographic and lithologic units defined by the shipboard party will be retained.

\section{Hole 482B}

Eight lithologic units, comprising at least sixteen cooling units, have been recognized in the drill core from Hole 482B (Fig. 2). The cooling units may be divided into two groups: those which are relatively thick $(5-10 \mathrm{~m})$ and those which are thinner (1-2 m) with glassy selvages. Both types are thought to represent submarine flows, rather than intrusive bodies or pillowed extrusions.

Petrographically, there are three main types of basalt: aphyric basalts (Units 1 and 8); sparsely plagioclase-phyric basalts, generally with less than 5 modal $\%$ total phenocrysts (Units 2, 3, and 4); and moderately plagioclase-olivine-clinopyroxene-phyric basalts with about 10 modal $\%$ total phenocrysts and less than 1 modal $\% \mathrm{cpx}$ (Units 5, 6, and 7). The basalts are generally fresh, with smectite(?) replacing olivine microlites and glass, and lining fractures and occasional vesicles. The samples from Units 4 and 5 are more altered than the other basalts from Hole 482B, which may correspond to a pause in the eruptive sequence. The presence of a hiatus is also suggested by a change in the stable NRM inclination between Units 3 and 4 .

Thirteen samples from Hole 482B were analyzed by $\mathrm{XRF}$ techniques (Table 2), and a further three by INAA techniques (Table 3 ). The basalts are all subalkaline tholeiites (Fig. 3), and have low contents of the moreHYG elements $(\mathrm{K}, \mathrm{Rb}, \mathrm{Ba}, \mathrm{Th}, \mathrm{Nb}, \mathrm{Ta}$, and the light rare earth elements). Essentially they resemble "depleted" mid-ocean ridge basalts (MORB) recovered from elsewhere along the EPR (e.g., Kay et al., 1970; Sun et al., 1979), from the Nazca Plate (Hart, 1976; Thompson et al., 1976) and from Site 474 on Leg 64 (Saunders et al., in press).

The basalts exhibit considerable downhole variation in chemistry (Fig. 2), but when plotted on $\mathrm{FeO}^{*} / \mathrm{MgO}$ variation diagrams (Fig. 4), two broad chemical types may be recognized: Type I basalts which show relative enrichment in the HYG elements (Units 1a, 7, and 8), and relatively depleted Type II basalts (Units 1b, 2, 3, 4, and 6) (Unit 5 was not analyzed during this study). There is no obvious correlation between phenocryst assemblages and the two-fold chemical division, but it should be noted that the shipboard party recognized six chemical types in this hole. Broadly speaking, Type I corresponds to their Types $\mathrm{A}, \mathrm{C}$, and E, and Type II to their Types B, D, and F. The two-fold division oversimplifies the real situation, since the shipboard party describes HYG-element enriched basalts $\left(\mathrm{TiO}_{2}=2.29 \%\right)$ from Sample 482B-19-1, $96 \mathrm{~cm}$, corresponding to Unit 4. In addition, the eight-fold lithologic division fails to distinguish between the Units $1 \mathrm{a}$ and $1 \mathrm{~b}$ (Figs. 3 and 4) which are chemically distinct. Notwithstanding these deficiencies, the two-fold division does allow an assessment of the main intra-hole variations. Note that the chemical types are intercalated, suggesting several successive episodes of extrusion.

The more-HYG/HYG element ratios are low in all of the basalts recovered from Hole 482B. For example, the $\mathrm{Ba} / \mathrm{Zr}$ ratio ranges from 0.15 to 0.25 (Fig. 5 ), the $\mathrm{Nb} / \mathrm{Zr}$ ratio is generally less than 0.02 (although the levels of 

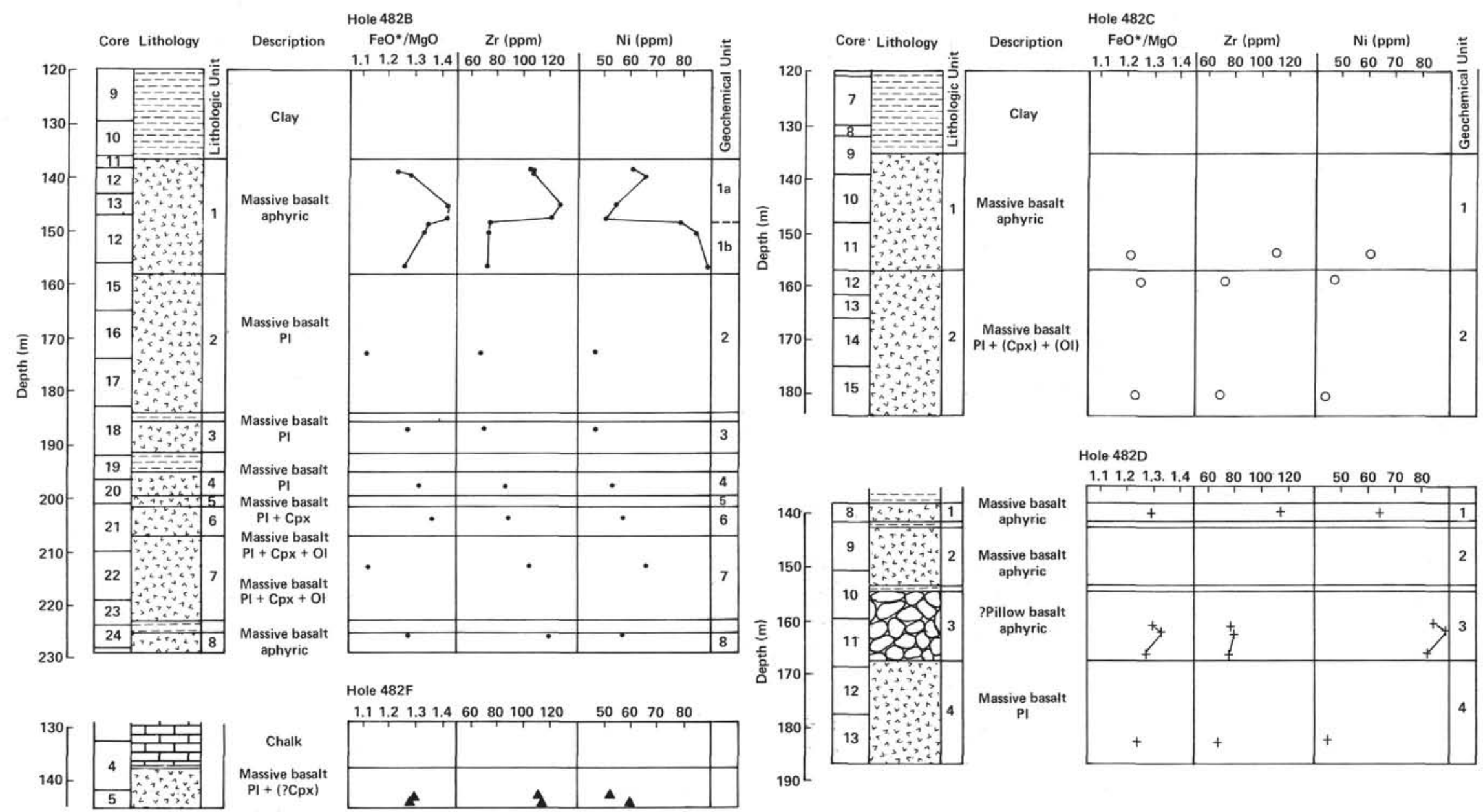

Figure 2. Lithology, mineralogy, and selected geochemical parameters vs. depth in Holes 482B, C, D, and F. (FeO* represents total iron.) 
Table 2. X-ray fluorescence analyses of basalts, Hole 482B.

\begin{tabular}{|c|c|c|c|c|c|c|c|c|c|c|c|c|c|}
\hline $\begin{array}{c}\text { Sample } \\
\text { (level in cm) }\end{array}$ & $12-2,86$ & $12-2,123$ & $13-2,91$ & $14-1,23$ & $14-1,119$ & $14-2,117$ & $15-1,70$ & $16-5,51$ & $18-2,59$ & $20-2,1$ & $21-2,24$ & $22-2,59$ & $24-1,77$ \\
\hline Unit & 1a & 1a & 1a & 1a & $1 \mathrm{~b}$ & $1 \mathrm{~b}$ & lb & 2 & 3 & 4 & 6 & 7 & 8 \\
\hline \multicolumn{14}{|c|}{ Major Elements (wt.\%) } \\
\hline $\mathrm{SiO}_{2}$ & 49.63 & 49.35 & 49.81 & 49.63 & 49.35 & 48.98 & 49.46 & 49.48 & 49.67 & 49.63 & 48.98 & 49.49 & 49.63 \\
\hline $\mathrm{TiO}_{2}$ & 1.85 & 1.89 & 2.27 & 2.00 & 1.48 & 1.49 & 1.44 & 1.35 & 1.33 & 1.54 & 1.59 & 1.76 & 2.03 \\
\hline $\mathrm{Al}_{2} \mathrm{O}_{3}$ & 14.91 & 15.26 & 14.74 & 15.26 & 15.28 & 15.28 & 15.29 & 15.34 & 15.36 & 15.33 & 15.32 & 15.94 & 14.96 \\
\hline $\mathrm{tFe}_{2} \mathrm{O}_{3}$ & 10.69 & 10.86 & 11.64 & 11.57 & 11.51 & 11.52 & 10.83 & 10.09 & 10.99 & 10.88 & 11.31 & 9.81 & 11.10 \\
\hline $\mathrm{MnO}$ & 0.16 & 0.16 & 0.14 & 0.18 & 0.19 & 0.18 & 0.17 & 0.15 & 0.16 & 0.16 & 0.18 & 0.13 & 0.14 \\
\hline $\mathrm{MgO}$ & 7.8 & 7.7 & 7.4 & 7.4 & 7.8 & 7.8 & 7.8 & 8.1 & 7.8 & 7.5 & 7.5 & 7.9 & 7.9 \\
\hline $\mathrm{CaO}$ & 11.48 & 11.56 & 10.27 & 11.31 & 12.22 & 12.28 & 11.93 & 11.66 & 12.15 & 12.23 & 12.11 & 11.33 & 11.25 \\
\hline $\mathrm{Na}_{2} \mathrm{O}$ & 2.66 & 2.70 & 2.86 & 2.76 & 2.45 & 2.44 & 2.48 & 2.49 & 2.47 & 2.62 & 2.55 & 2.79 & 2.79 \\
\hline $\mathrm{K}_{2} \mathrm{O}$ & 0.11 & 0.08 & 0.10 & 0.08 & 0.06 & 0.06 & 0.05 & 0.07 & 0.06 & 0.04 & 0.03 & 0.07 & 0.07 \\
\hline $\mathrm{P}_{2} \mathrm{O}_{5}$ & 0.20 & 0.19 & 0.19 & 0.19 & 0.09 & 0.09 & 0.10 & 0.13 & 0.11 & 0.14 & 0.13 & 0.17 & 0.22 \\
\hline LOI & - & - & 0.69 & - & - & - & - & +0.17 & - & - & +0.02 & - & 0.13 \\
\hline Total & 99.49 & 99.70 & 100.10 & 100.38 & 100.38 & 100.12 & 99.50 & 98.67 & 100.10 & 100.07 & 99.67 & 99.34 & 100.18 \\
\hline \multicolumn{14}{|c|}{ Trace Elements (ppm) } \\
\hline $\mathrm{Ni}$ & 61 & 66 & 55 & 51 & 79 & 85 & 89 & 46 & 47 & 53 & 57 & 66 & 57 \\
\hline $\mathrm{Cr}$ & 232 & 236 & 183 & 202 & 220 & 212 & 202 & 153 & 156 & 183 & 166 & 215 & 181 \\
\hline $\mathrm{Zn}$ & 69 & 67 & 84 & 79 & 77 & 72 & 74 & 65 & 72 & 70 & 77 & 66 & 66 \\
\hline $\mathrm{Ga}$ & 18 & 19 & 26 & 23 & 22 & 18 & 19 & 18 & 12 & 11 & 16 & 14 & 13 \\
\hline $\mathrm{Rb}$ & $<1$ & $<1$ & 0.1 & $<1$ & $<1$ & 0.5 & $<1$ & $<1$ & 0.3 & 0.4 & 0.9 & 0.4 & $<1$ \\
\hline $\mathrm{Sr}$ & 112 & 107 & 112 & 109 & 94 & 96 & 96 & 93 & 93 & 99 & 91 & 130 & 113 \\
\hline $\mathrm{Y}$ & 39 & 39 & 46 & 44 & 33 & 33 & 32 & 29 & 30 & 36 & 33 & 34 & 42 \\
\hline $\mathrm{Zr}$ & 106 & 108 & 128 & 121 & 75 & 76 & 74 & 68 & 71 & 86 & 89 & 102 & 119 \\
\hline $\mathrm{Nb}$ & 2 & 2 & 3 & 2 & 2 & 1 & 2 & 2 & i & 2 & 3 & 2 & 3 \\
\hline $\mathrm{Ba}$ & 21 & 17 & 31 & 25 & 16 & 16 & 18 & 17 & 16 & 21 & 19 & 15 & 26 \\
\hline $\mathrm{La}$ & 6 & 5 & 6 & 6 & 3 & 3 & 4 & 3 & 3 & 3 & 5 & 5 & 5 \\
\hline $\mathrm{Ce}$ & 13 & 14 & 14 & 15 & 8 & 11 & 8 & 10 & 10 & 12 & 13 & 13 & 15 \\
\hline $\mathrm{Nd}$ & 12 & 12 & 13 & 12 & 8 & 9 & 9 & 8 & 8 & 11 & 10 & 11 & 14 \\
\hline \multicolumn{14}{|l|}{ Selected Ratios } \\
\hline $\mathrm{FeO} * / \mathrm{MgO}$ & 1.23 & 1.28 & 1.42 & 1.41 & 1.34 & 1.33 & 1.26 & 1.12 & 1.27 & 1.31 & 1.36 & 1.12 & 1.27 \\
\hline $\mathrm{Zr} / \mathrm{Nb}$ & 53 & 54 & 43 & 61 & 38 & 76 & 37 & 34 & 71 & 43 & 30 & 51 & 40 \\
\hline $\mathrm{Ti} / \mathrm{Zr}$ & 105 & 105 & 106 & 99 & 118 & 118 & 117 & 119 & 112 & 107 & 107 & 103 & 102 \\
\hline $\mathrm{Ba} / \mathrm{Zr}$ & 0.20 & 0.16 & 0.24 & 0.21 & 0.21 & 0.21 & 0.24 & 0.25 & 0.23 & 0.24 & 0.21 & 0.15 & \\
\hline $\mathrm{K} / \mathrm{Rb}$ & $>900$ & $>650$ & $>800$ & $>650$ & $>500$ & $>500$ & $>400$ & $>600$ & $>500$ & $>300$ & $>250$ & $>600$ & $>600$ \\
\hline $\mathrm{Ba} / \mathrm{Sr}$ & 0.19 & 0.16 & 0.28 & 0.23 & 0.17 & 0.17 & 0.18 & 0.18 & 0.17 & 0.21 & 0.21 & 0.12 & 0.23 \\
\hline$(\mathrm{Ce} / \mathrm{Y})_{\mathrm{N}}$ & 0.8 & 0.9 & 0.8 & 0.8 & 0.6 & 0.8 & 0.6 & 0.9 & 0.8 & 0.8 & 1.0 & 1.0 & 0.9 \\
\hline \multicolumn{14}{|c|}{ CIPW Norms (\%) } \\
\hline Or & 0.7 & 0.5 & 0.6 & 0.5 & 0.4 & 0.4 & 0.3 & 0.4 & 0.4 & 0.2 & 0.2 & 0.4 & 0.4 \\
\hline $\mathrm{Ab}$ & 22.5 & 22.8 & 24.2 & 23.4 & 20.7 & 20.6 & 21.0 & 21.1 & 20.9 & 22.2 & 21.6 & 23.6 & 23.6 \\
\hline An & 28.4 & 29.3 & 27.1 & 29.0 & 30.5 & 30.6 & 30.4 & 30.5 & 30.6 & 30.0 & 30.3 & 30.8 & 28.1 \\
\hline $\mathrm{Di}$ & 22.2 & 21.8 & 18.5 & 21.1 & 24.1 & 24.3 & 22.9 & 21.6 & 23.6 & 24.3 & 23.7 & 19.8 & 21.4 \\
\hline Hy & 15.2 & 13.3 & 20.2 & 14.6 & 12.1 & 10.4 & 14.5 & 15.7 & 13.7 & 11.8 & 11.2 & 12.9 & 14.3 \\
\hline ol & 3.7 & 5.1 & 1.1 & 4.5 & 6.5 & 7.7 & 4.5 & 4.1 & 5.3 & 5.5 & 6.5 & 5.6 & 4.9 \\
\hline Mt & 1.8 & 1.9 & 2.0 & 2.0 & 2.0 & 2.0 & 1.9 & 1.7 & 1.9 & 1.9 & $\cdot 2.0$ & 1.7 & 1.9 \\
\hline II & 3.5 & 3.6 & 4.3 & 3.8 & $2.8^{\circ}$ & 2.8 & 2.7 & 2.6 & 2.5 & 2.9 & 3.0 & 3.3 & 3.9 \\
\hline Ap & 0.5 & 0.5 & 0.4 & 0.4 & 0.2 & 0.2 & 0.2 & 0.3 & 0.3 & 0.3 & 0.3 & 0.4 & 0.5 \\
\hline
\end{tabular}

Note: $\mathrm{Fe}_{2} \mathrm{O}_{3}=$ total iron as $\mathrm{Fe}_{2} \mathrm{O}_{3} ; \mathrm{LOI}=\mathrm{Total}$ loss on ignition; $\mathrm{FeO} *=$ total iron as $\mathrm{FeO} ;(\mathrm{Ce} / \mathrm{Y})_{\mathrm{N}}=\mathrm{Chondrite-normalized} \mathrm{Ce} / \mathrm{Y}$ ratio; $\mathrm{CIPW}$ norms determined assuming an $\mathrm{Fe}_{2} \mathrm{O}_{3} / \mathrm{FeO}$ ratio of 0.15 .

$\mathrm{Nb}$ approach the detection limit) and the $\mathrm{Ce}_{\mathrm{N}} / \mathrm{Y}_{\mathrm{N}}$ ratios (where $\mathrm{Ce}_{\mathrm{N}} / \mathrm{Y}_{\mathrm{N}}$ is the chondrite-normalized $\mathrm{Ce} / \mathrm{Y}$ ratio) are less than 1. Biaxial plots of precisely measured immobile HYG elements, particularly $\mathrm{Ti}, \mathrm{Zr}$, and $\mathrm{Y}$ reveal that the $\mathrm{Zr} / \mathrm{Y}$ and $\mathrm{Zr} / \mathrm{Ti}$ ratios increase in a systematic fashion with increasing fractionation. This is clearly shown in Figures 6 and 7, where the trends have positive intercepts on the $\mathrm{Y}$ and $\mathrm{Ti}$ axes, respectively.

$\mathrm{K}_{2} \mathrm{O}, \mathrm{Rb}, \mathrm{Ba}$, and $\mathrm{Sr}$ all have low concentrations (in the case of $\mathrm{Rb}$, generally below the level of detection), indicating that low temperature alteration of these samples is minimal. The $\mathrm{Sr} / \mathrm{Zr}$ ratios (Fig. 8) decrease with increasing $\mathrm{Zr}$ content, which suggests that plagioclase fractionation has occurred. $\mathrm{The} \mathrm{Sr} / \mathrm{Zr}$ ratios are similar to those observed in the basement samples recovered at Site 474 , but are significantly lower than those in the samples from the Guaymas Basin, where Sr frequently exceeds $200 \mathrm{ppm}$.
Chondrite-normalized rare earth element (REE) data for the basalts from Holes 482B and 482D are presented in Figure 9. All of the basalts show relative light REE depletion, with $\mathrm{La}_{\mathrm{N}} / \mathrm{Yb}_{\mathrm{N}}$ ratios increasing from 0.4 to 0.55 with increasing La content. The $\mathrm{Th} / \mathrm{Hf}$ ratios are low (Table 3), a feature typical of depleted MORB (e.g., Wood et al., 1979a; Tarney et al., 1980). Samples 482B$15-1,70-72 \mathrm{~cm}$ and 482B-18-2, 59-61 cm have slight but significant positive Eu anomalies, and although this may be the result of plagioclase accumulation in Unit 3, Unit $1 \mathrm{~b}$ is aphyric.

\section{Hole 482C}

The lithologic column recovered in this hole comprises two units (Fig. 2). Unit 1 ( $21.5 \mathrm{~m}$ thick) consists of massive aphyric basalt, whereas Unit 2 ( $27 \mathrm{~m}$ thick), consists of massive, sparsely plagioclase-, clinopyroxene-, and olivine-phyric basalt, with plagioclase being 
Table 3. Neutron activation analyses of selected basalts, Site 482 .

\begin{tabular}{lcccc}
\hline $\begin{array}{c}\text { Sample } \\
\text { (interval in cm) }\end{array}$ & $\begin{array}{c}482 \mathrm{~B}-13-2, \\
91-93\end{array}$ & $\begin{array}{c}482 \mathrm{~B}-15-1, \\
70-72\end{array}$ & $\begin{array}{c}482 \mathrm{~B}-18-2, \\
59-61\end{array}$ & $\begin{array}{c}482 \mathrm{D}-8-1, \\
61-63\end{array}$ \\
Unit & $1 \mathrm{a}$ & $1 \mathrm{~b}$ & 3 & 1 \\
\hline \multicolumn{2}{c}{ Rare Earth Elements (ppm) } & & & \\
$\mathrm{La}$ & 4.1 & 2.5 & 2.2 & 3.5 \\
$\mathrm{Ce}$ & 16.3 & 10.0 & 10.3 & 15.0 \\
$\mathrm{Nd}$ & 14.3 & 9.2 & 8.8 & 12.2 \\
$\mathrm{Sm}$ & 5.01 & 3.32 & 2.98 & 4.15 \\
$\mathrm{Eu}$ & 2.01 & 1.5 & 1.38 & 1.61 \\
$\mathrm{Gd}$ & 6.8 & 5.1 & 4.5 & 5.8 \\
$\mathrm{~Tb}$ & 1.28 & 0.88 & 0.86 & 1.12 \\
Tm & n.a. & 0.57 & 0.60 & 0.71 \\
Yb & 5.3 & 3.9 & 3.7 & 4.3 \\
$\mathrm{Lu}$ & 0.89 & 0.65 & 0.64 & 0.78 \\
Selected Ratios & & & & \\
Th & & & & \\
Ta & 0.20 & 0.11 & 0.12 & n.a. \\
Hf & n.a. & n.a. & n.a. & 0.14 \\
LaN/YbN & 4.70 & 3.15 & 2.66 & 3.39 \\
La/Ta & 0.53 & 0.44 & 0.39 & 0.55 \\
Th/Hf & - & - & - & 25 \\
\hline
\end{tabular}

Note: n.a. $=$ not analyzed.

less than 5 modal $\%$. It is believed that both of these units are extrusive in origin and that they are the lateral equivalents of Units 1a and 2 from Hole 482B (the two holes are no more than $100 \mathrm{~m}$ apart). In general, the basalts drilled in Hole $482 \mathrm{C}$ show similar degrees of alteration to those from Hole 482B, i.e., they display smectite lining vesicles and hairline fractures, and replacing olivine and the mesostasis. Higher degrees and grades of alteration have been reported in Sections 482C-10-2 through 11-2, but this interval was not sampled during the present study.
Analyses of the samples from Hole $482 \mathrm{C}$ are given in Table 4. All of the basalts are subalkaline tholeiites (Fig. 3 ), but Unit 1 has a high content of HYG elements relative to Unit 2. In fact, Unit 1 is chemically indistinguishable from Unit 1a in Hole 482B (Chemical Type I), and Unit 2 is similar to Units 2 and 3 in Hole 482B (Fig. 4) (Chemical Type II). The equivalent of Unit 482B-1b was not sampled during the present study but it was noted by the shipboard party. As in Hole 482B, therefore, Unit $482 \mathrm{C}-1$ consists of two chemically distinct subunits.

The basalts from Hole 482B possess the low moreHYG/HYG element ratios observed in the Hole 482B basalts and fall along similar chemical trends (Figs. 4-8). The LIL-element contents are again low, indicating that secondary alteration is slight.

\section{Hole 482D}

A total of 48.5 meters of basalt was drilled in this hole, and although at least 16 cooling units were observed, four main lithologic units were recognized by the shipboard party (Fig. 2). Units 1 and 2 consist of aphyric to very sparsely plagioclase-phyric massive basalt. Unit 3, consisting of several thin cooling units with glassy margins, probably represents a pillow basalt. Unit 4 is a massive basalt containing up to 2 modal $\%$ plagioclase phenocrysts in glomerophyric clots with clinopyroxene. The boundary between Units 3 and 4 coincides with a major change in magnetic inclination. As in Holes $482 \mathrm{~B}$ and $482 \mathrm{C}$, low-temperature alteration is found throughout the section but is most intense in the upper 10 to 15 meters of the basement. It is generally expressed as smectite development within the mesostasis and within hairline fractures and rare vesicles.

Five XRF analyses of basalts from Hole 482D are presented in Table 4, and one INA analysis is included in Table 3. No samples from Unit 2 were analyzed dur-

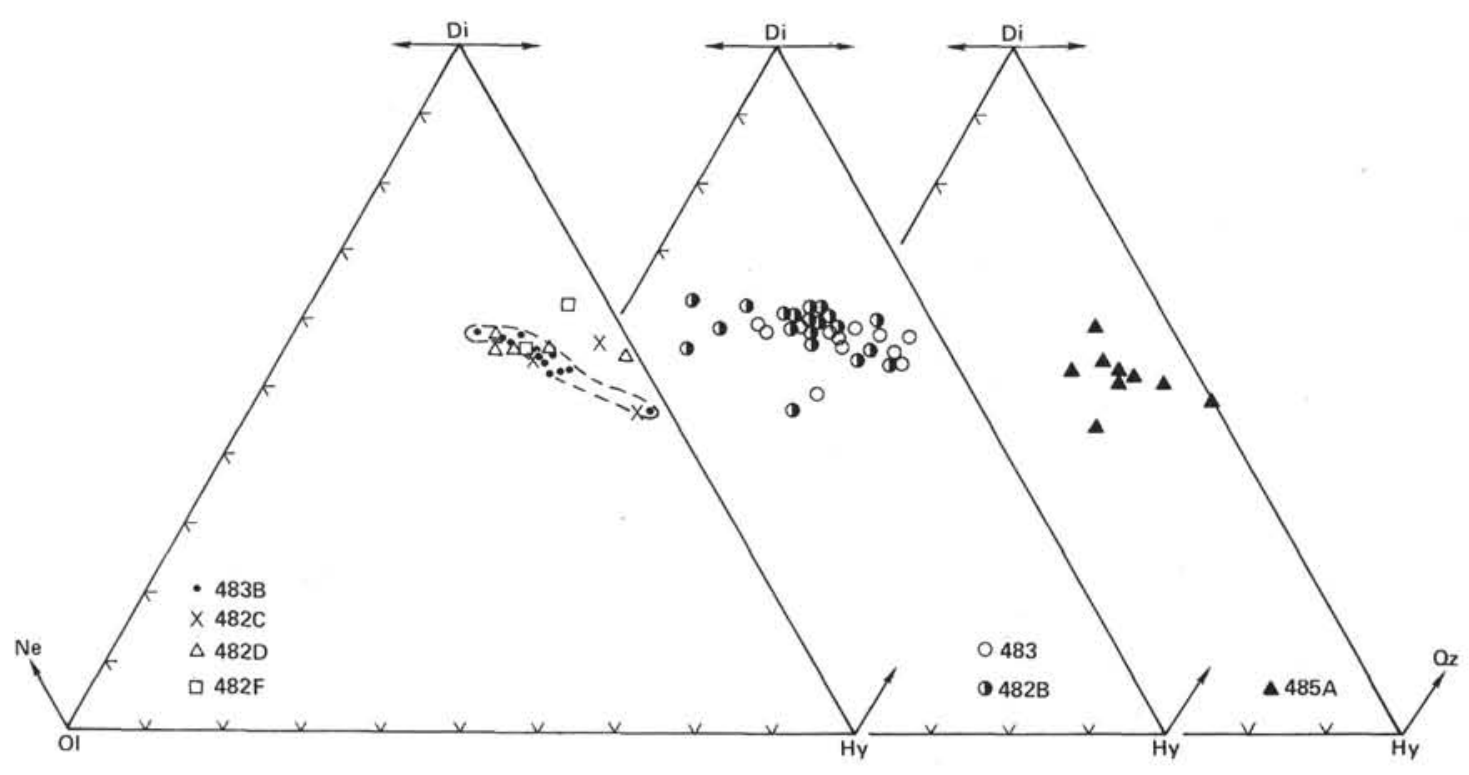

Figure 3. Leg 65 basalts plotted on the nepheline (Ne)-olivine (Ol)-diopside (Di)-hypersthene (Hy)-quartz (Qz) normative tetrahedron. ( $\mathrm{Fe}_{2} \mathrm{O}_{3} / \mathrm{FeO}^{*}$ ratio assumed to be 0.15 for the calculation of $\mathrm{CIPW}$ normative values.) 


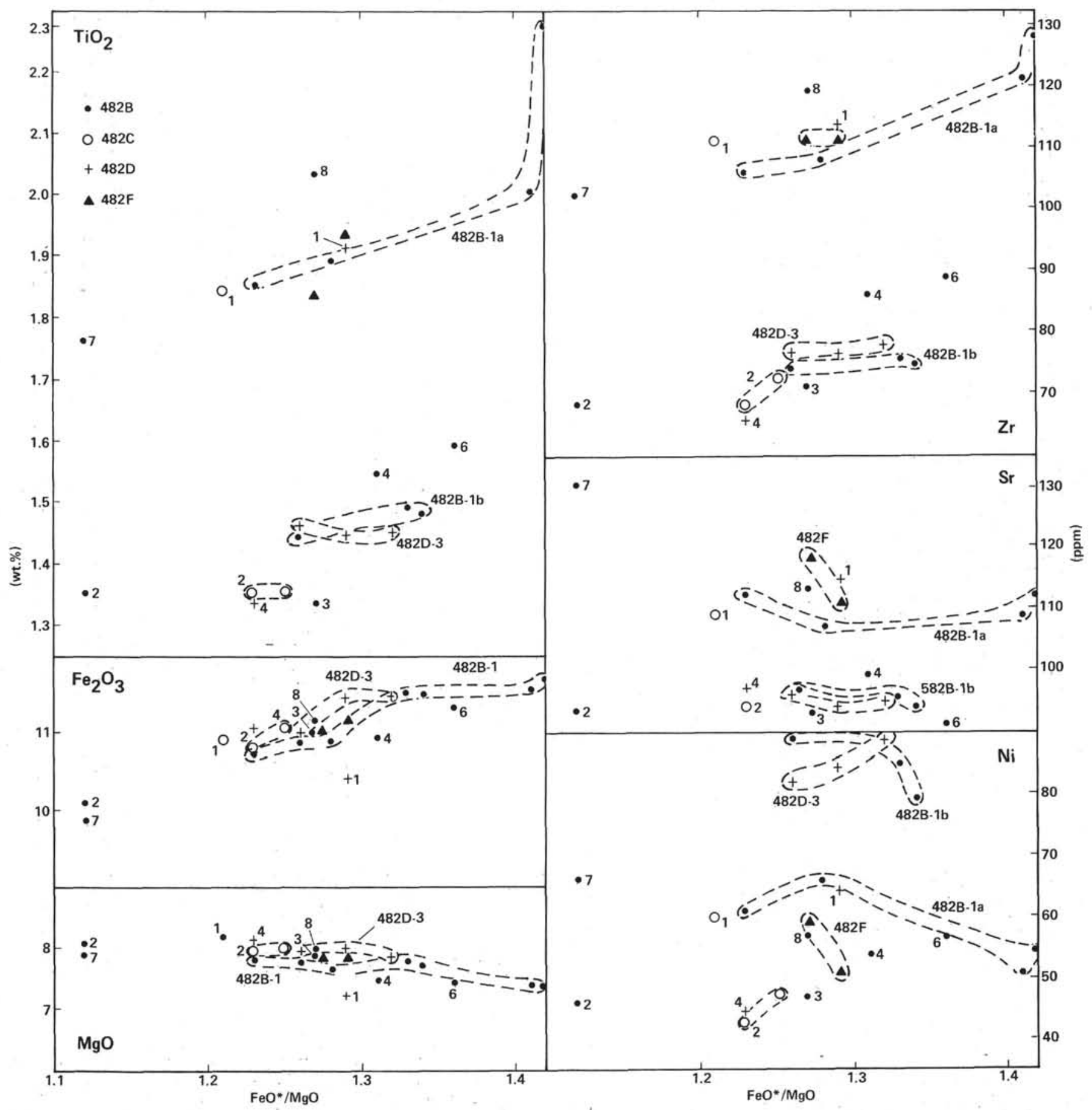

Figure 4. Selected major element oxides and trace elements vs. $\mathrm{FeO}^{*} / \mathrm{MgO}$ ratio, Site 482 . $\left(\mathrm{tFe}_{2} \mathrm{O}_{3}=\right.$ total iron as $\mathrm{Fe}_{2} \mathrm{O}_{3} ; \mathrm{FeO}^{*}=$ total iron as $\mathrm{FeO}$. Numbering of chemical units as in Fig. 2).

ing the present study. As in the previous holes, the basalts are all subalkaline tholeiites (Fig. 3) and have very low abundances of the more-HYG elements. The basalts again display considerable downhole variation in chemistry, which relates to the lithologic units (Fig. 2); Unit 1 is HYG-element enriched relative to Units 3 and 4 and is chemically indistinguishable from Units 482B-1a and 482C-1a. Unit 482D-3 clearly resembles Unit 482B-1b (see, for example, $\mathrm{Zr}, \mathrm{Ni}$, and $\mathrm{FeO}^{*} / \mathrm{MgO}$ versus depth in Fig. 4). Unit $482 \mathrm{D}-4$ has a similar composition to
Unit 482C-2 and, to a certain extent, Unit 482B-3. Sample $482 \mathrm{D}-8-1,61-63 \mathrm{~cm}$ has a $\mathrm{La}_{\mathrm{N}} / \mathrm{Yb}_{\mathrm{N}}$ ratio of 0.55 (Fig. 9), which is virtually identical to that of the Hole 482B basalts, and a La/Ta ratio of 25 (Table 3 ).

The LIL-element concentrations are generally very low, again suggesting that secondary alteration has had little effect on the whole-rock chemistry. However, Sample 482D-8-1, 61-63 cm is relatively enriched in $\mathrm{K}_{2} \mathrm{O}$ and $\mathrm{Rb}$ (e.g., $\mathrm{K} / \mathrm{Zr}=29$, as opposed to a value of 6 in Unit 3 in Hole 482D, corroborating petrographic evi- 


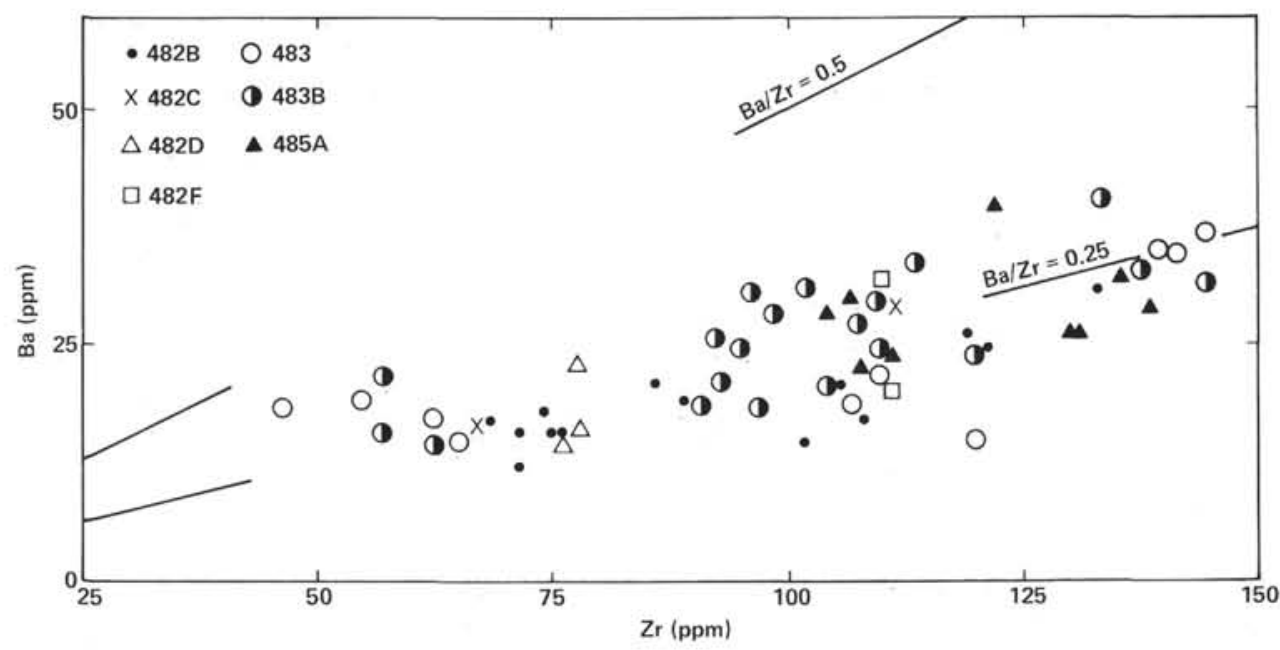

Figure 5. Ba vs. $\mathrm{Zr}$ for the basalts drilled on Leg 65 .

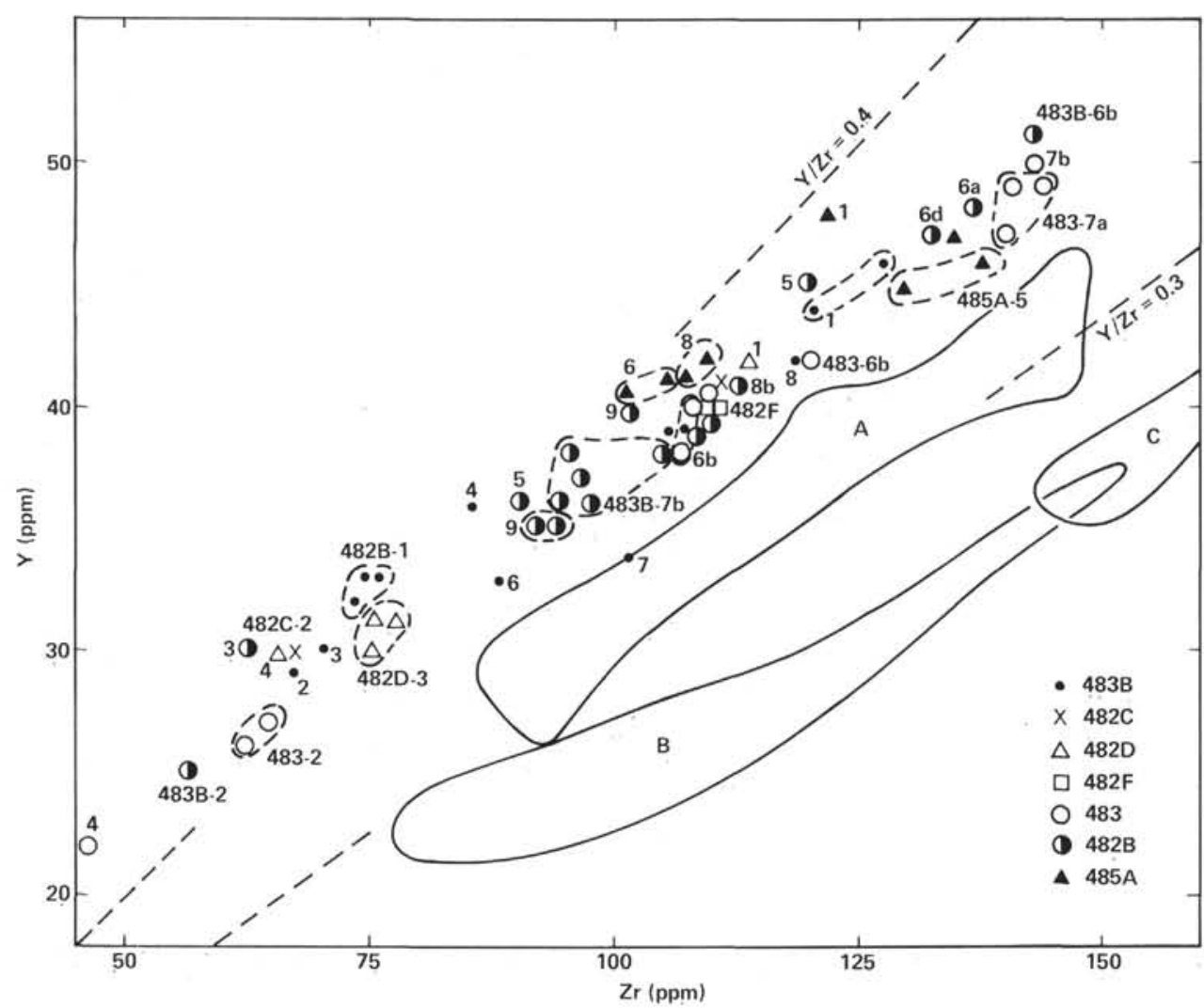

Figure 6. Y vs. $\mathrm{Zr}$ basalts recovered on Leg 65 . (Note that the trend of the Leg 65 basalts has a positive intercept on the $\mathrm{Y}$ axis. Fields outlined by continuous lines represent Site 474 basalts [A], and Guaymas Basin samples from Sites 477 and 478 [B] and Site 481 [C] [Saunders et al., in press.].)

dence that the upper part of the basement has been more extensively altered than the lower part.

\section{Hole 482F}

The basement in Hole $482 \mathrm{~F}$ was reached at about 140 meters sub-bottom and approximately two meters of basalt were recovered in Sections 482F-4-3, 482F-5-1, and $482 \mathrm{~F}-5-2$. The basalt is very sparsely plagioclase-phyric, contains rare smectite-filled vesicles and is only slightly altered.

Chemically, the basalt is a subalkaline tholeiite, with low more-HYG/HYG element ratios, but with relatively high HYG-element contents similar to those of Units 482B-1a, 482C-1, and 482D-1. It therefore approximates Chemical Type I in composition. The basalt does, however, have a slightly higher content of $\mathrm{Sr}$ than does 


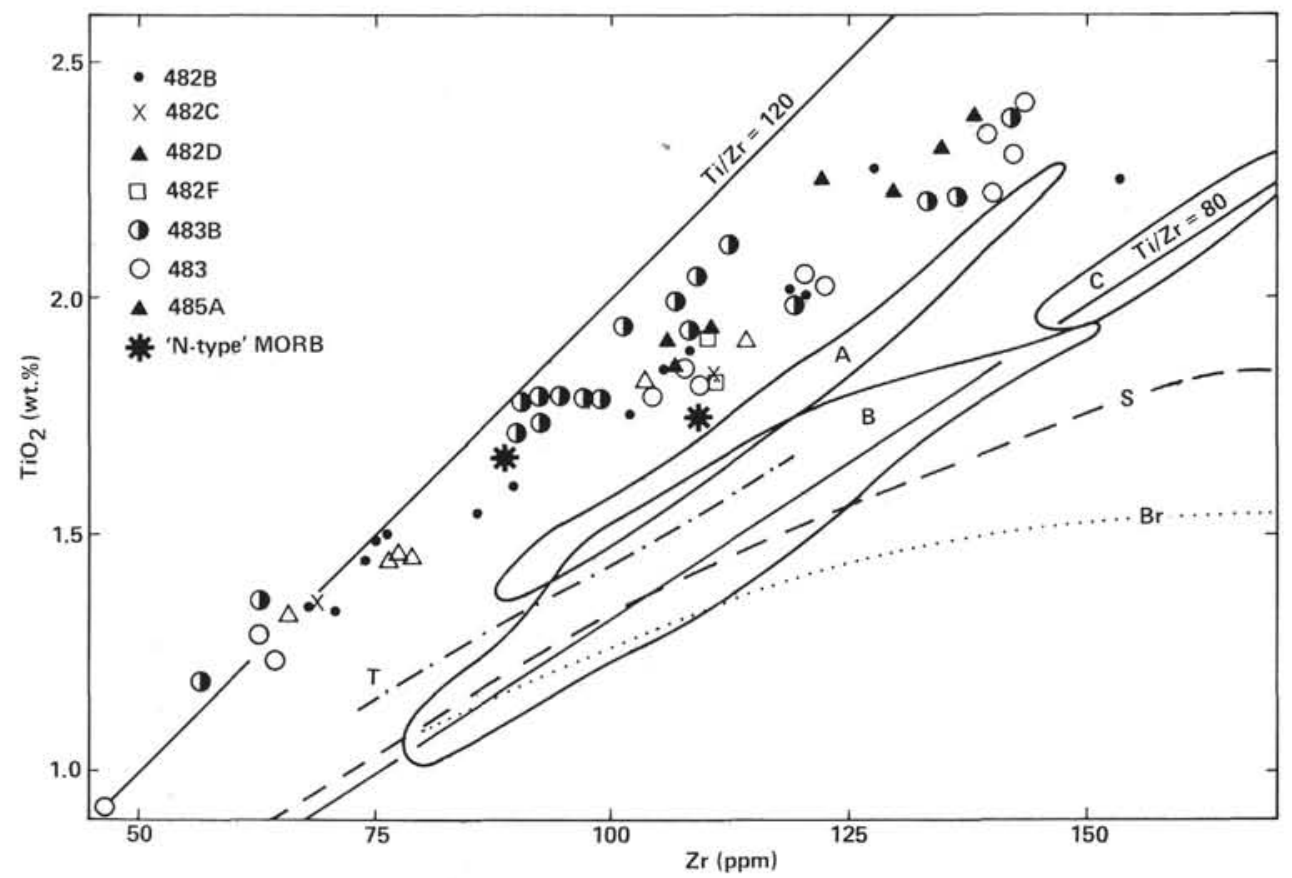

Figure 7. $\mathrm{TiO}_{2}$ vs. $\mathrm{Zr}$ for the basalts recovered on Leg 65. (Note the positive intercept on the $\mathrm{TiO}_{2}$ axis. Fields $\mathrm{A} \mathrm{B}$, and $\mathrm{C}$ as in Fig. 6 . S refers to the trend shown by mafic rocks from the Sarmiento (backarc) ophiolite complex, Chile [Saunders et al., 1979]; T refers to the trend shown by the Tortuga Ophiolite, Chile (Stern, 1979); Br represents the trend common to mafic volcanic rocks from Deception, Bridgeman, and Penguin Islands, in Bransfield Strait, an ensialic back-arc basin on the Antarctic Peninsula [Weaver et al., 1979]. The "N-type" MORB [mid-ocean ridge basalt] data points are EPR basalts analyzed by Sun et al. [1979].)

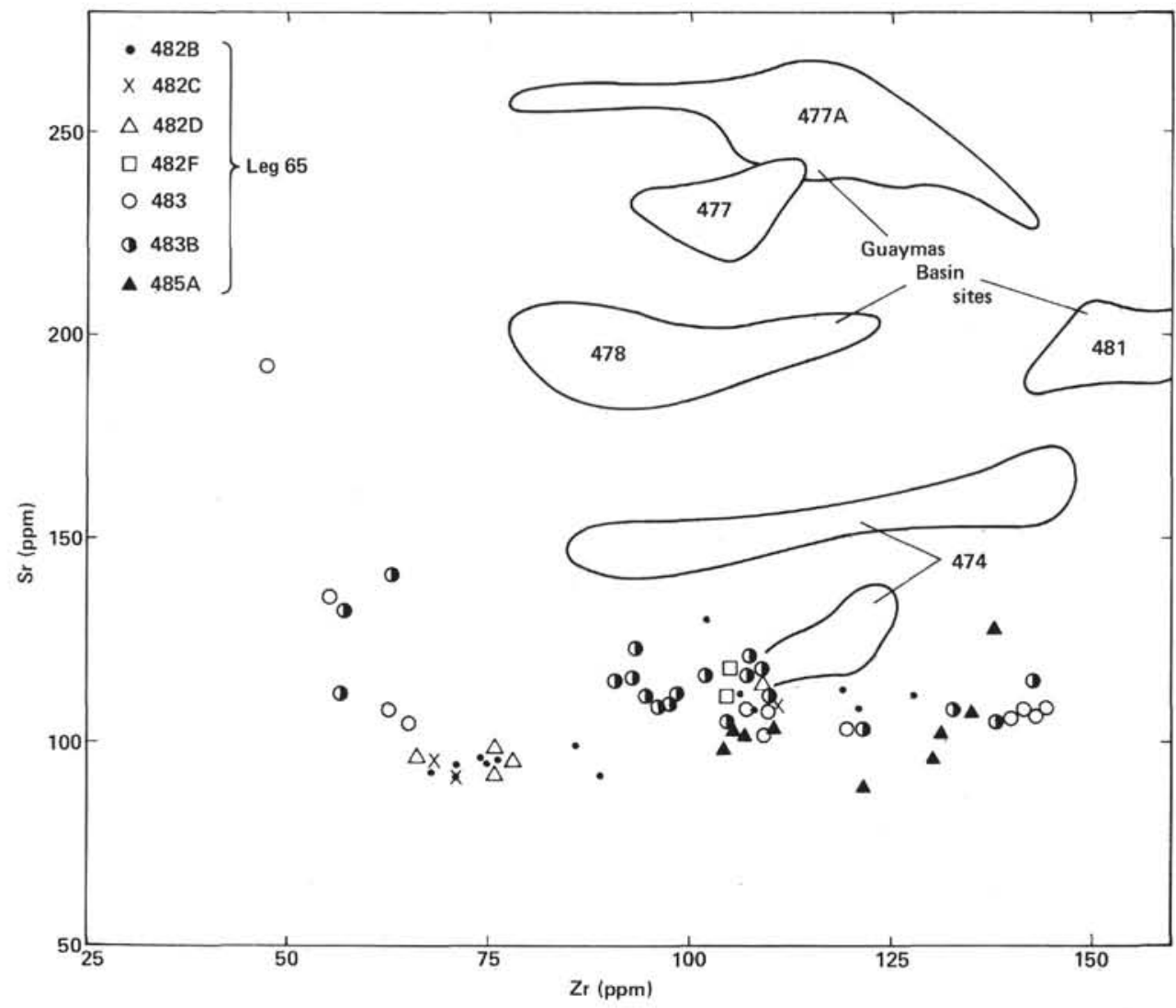

Figure 8. Sr vs. $\mathrm{Zr}$ for the basalts recovered on Leg 65 . (Fields for Leg 64 basalts from Saunders et al. [in press].) 


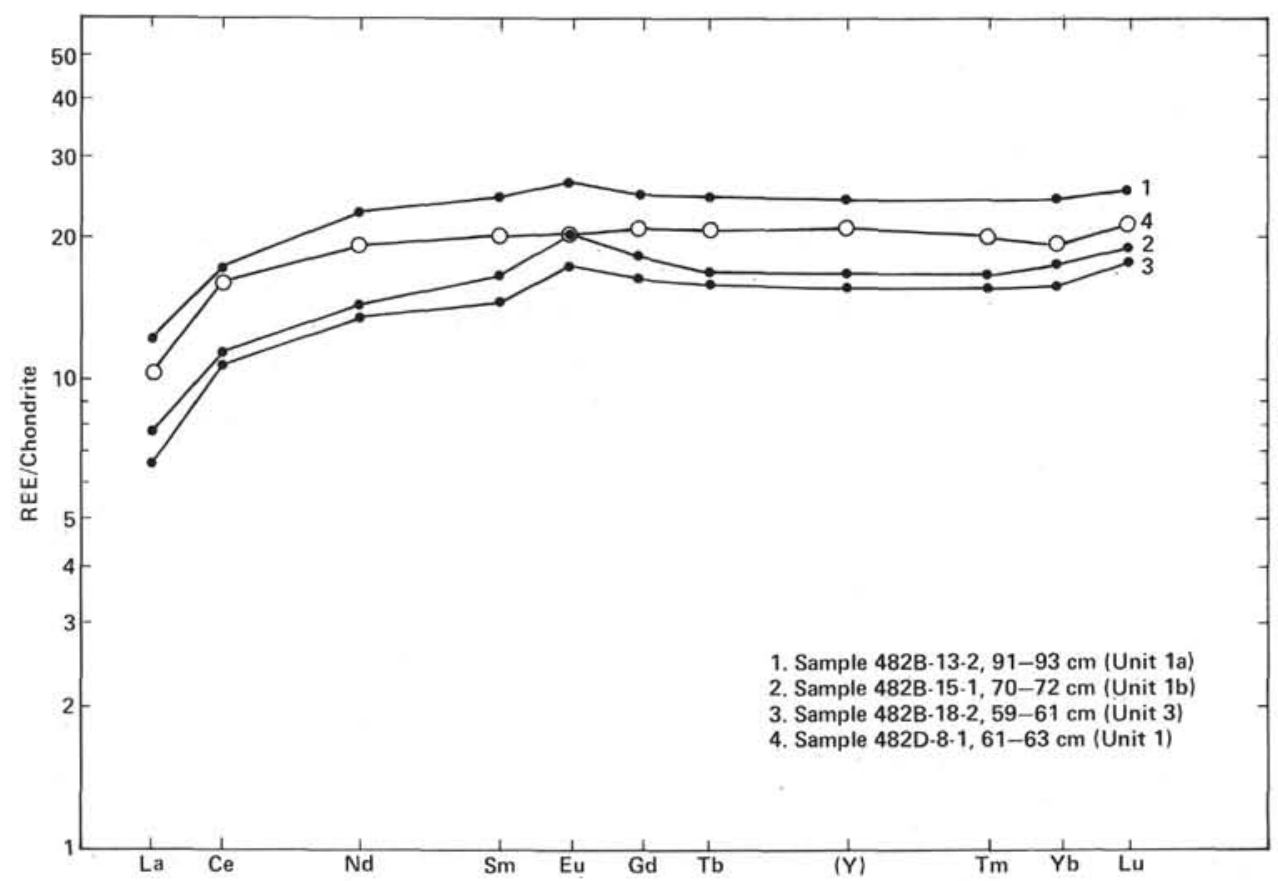

Figure 9. Chondrite-normalized rare earth element (REE) patterns for selected basalts from Site 482. (Y values were determined by XRF, the remainder by INAA.)

482B-1a (which may be a function of secondary alteration) (Fig. 4), and a slightly lower Ni content.

\section{Site 482: Discussion}

The main interhole chemical variations at Site 482 are illustrated by Figures 2 and 4 . Apart from the broad grouping into two chemical types, I and II, it has proved possible to correlate lithologic units between holes on the basis of both petrography and chemistry. Thus, Unit 482B-1a correlates with Units 482C-1, 482D-1, and the partially recovered flow from Hole 482F; Unit 482B-1b correlates with the lower part of Unit 482C-1 (not sampled here) and Unit 482D-3; however, Unit 482B-2 does not obviously correlate with any other unit although on the basis of flow thickness it would be expected to correlate with Unit 2 in Hole $482 \mathrm{C}$. On a chemical basis, Unit $482 \mathrm{C}-2$ correlates better with Unit 482D-4 and possibly 482B-3. The limited amount of basement penetration in Holes $482 \mathrm{C}$, D, and F means that the lateral equivalents of Units 482B-4, 5, 6, 7, and 8 were not recovered.

The strong lithologic correlation between the holes at Site $\mathbf{4 8 2}$ has important implications for the nature of the ocean crust in this region. Normally, and particularly along the Mid-Atlantic Ridge, Oceanic Layer 2 is composed of a series of pillow basalts and intercalated sediments, but Site 482 demonstrates that in this part of the Gulf, the dominant lithology consists of massive basalts, apparently emplaced as flows rather than sills. In addition, it is probable that individual units are continuous for hundreds of meters across the seafloor, implying either that single flows are laterally very extensive, or that identical magma types were simultaneously erupted from several centers (or fissures).
Chemically, the basalts from Site 482 all resemble the more-HYG element-depleted normal (or N-type) midocean ridge basalts recovered elsewhere along the EPR (e.g., Kay et al., 1970; Hart, 1976; Thompson et al., 1976; Sun et al., 1979). In addition, the constancy of the more-HYG/more HYG element ratios (e.g., La/Th) and the more-HYG/HYG element ratios (Th/Hf, La/ $\mathrm{Yb}, \mathrm{Nb} / \mathrm{Zr}$ ) and the consistent values of several HYG/ HYG element ratios $(\mathrm{Y} / \mathrm{Zr}, \mathrm{Ti} / \mathrm{Zr})$, strongly suggest that all of the basalts were derived from compositionally identical sources, if not the same source, under similar conditions of partial melting.

Certainly, it would appear that some chemical variations can be explained by simple closed-system fractional crystallization. This may be true, for example, of the intraunit variation in Units 482B-1a and 482B-1b. However, the chemical differences between different units, and particularly between Chemical Types I and II, cannot be accounted for by such a simple process. Thus, although the successive enrichment in HYG elements between Units 482C-2 and 482B-6 (both belonging to Chemical Type II) may be produced by the removal of olivine, plagioclase, or clinopyroxene crystals, the abundance of $\mathrm{Ni}$ would be significantly reduced by the extraction of olivine or clinopyroxene (e.g., Leeman, 1973; Hart and Davis, 1978). This in general is not observed. Therefore, while the constituent units of Chemical Type II may be derived from a common parental magma, there is no evidence to support the idea that the units can be related directly to each other by fractional crystallization. Similar arguments apply to Chemical Type I.

It is also necessary to explain the chemical differences between Chemical Types I and II. Again, simple closedsystem fractionation could not produce the observed en- 
Table 4. X-ray fluorescence analyses of basalts, Holes $482 \mathrm{C}, 482 \mathrm{D}$, and $482 \mathrm{~F}$.

\begin{tabular}{|c|c|c|c|c|c|c|c|c|c|c|}
\hline $\begin{array}{c}\text { Sample } \\
\text { (level in } \mathrm{cm} \text { ) }\end{array}$ & $\begin{array}{c}482 C-11-4 \\
92\end{array}$ & $\begin{array}{c}482 C-12-1 \\
92\end{array}$ & $\begin{array}{c}482 C-15-3 \\
100\end{array}$ & $\begin{array}{c}\text { 482D-8-1, } \\
61\end{array}$ & $\begin{array}{c}\text { 482D-11-1, } \\
86\end{array}$ & $\begin{array}{c}482 \mathrm{D}-11-2, \\
94\end{array}$ & $\begin{array}{c}482 \mathrm{D}-12-1 \\
98\end{array}$ & $\begin{array}{c}482 \mathrm{D}-13-3 \\
24\end{array}$ & $\begin{array}{c}482 \mathrm{~F}-5-1 \\
148\end{array}$ & $\begin{array}{c}482 F-5-2 \\
72\end{array}$ \\
\hline Unit & 1 & 2 & 2 & 1 & 3 & 3 & 3 & 4 & - & - \\
\hline \multicolumn{11}{|c|}{ Major Elements (wt.\%) } \\
\hline $\mathrm{SiO}_{2}$ & 49.72 & 50.04 & 49.47 & 49.67 & 49.41 & 49.27 & 49.58 & 49.66 & 49.38 & 49.74 \\
\hline $\mathrm{TiO}_{2}$ & 1.84 & 1.30 & 1.35 & 1.91 & 1.44 & 1.45 & 1.46 & 1.34 & 1.93 & 1.83 \\
\hline $\mathrm{Al}_{2} \mathrm{O}_{3}$ & 15.05 & 14.92 & 15.53 & 14.85 & 15.03 & 15.34 & 15.42 & 15.17 & 15.13 & 15.47 \\
\hline $\mathrm{tFe}_{2} \mathrm{O}_{3}$ & 10.90 & 11.10 & 10.68 & 10.40 & 11.49 & 11.46 & 10.92 & 11.03 & 11.18 & 11.01 \\
\hline $\mathrm{MnO}$ & 0.16 & 0.15 & 0.16 & 0.30 & 0.19 & 0.18 & 0.16 & 0.16 & 0.18 & 0.18 \\
\hline $\mathrm{MgO}$ & 8.1 & 8.0 & 7.8 & 7.2 & 8.0 & 7.8 & 7.8 & 8.1 & 7.9 & 7.8 \\
\hline $\mathrm{CaO}$ & 10.98 & 12.08 & 12.21 & 11.69 & 12.08 & 12.03 & 11.98 & 12.08 & 11.51 & 11.79 \\
\hline $\mathrm{Na}_{2} \mathrm{O}$ & 2.52 & 2.27 & 2.45 & 2.36 & 2.35 & 2.53 & 2.61 & 2.54 & 2.67 & 2.71 \\
\hline $\mathrm{K}_{2} \mathrm{O}$ & 0.08 & 0.06 & 0.03 & 0.40 & 0.05 & 0.05 & 0.06 & 0.07 & 0.09 & 0.06 \\
\hline $\mathrm{P}_{2} \mathrm{O}_{5}$ & 0.21 & 0.11 & 0.12 & 0.17 & 0.08 & 0.09 & 0.12 & 0.12 & 0.20 & 0.18 \\
\hline LÖI & 0.13 & 0.13 & 0.42 & 0.71 & - & - & - & 0.06 & 0.53 & 0.24 \\
\hline Total & 99.73 & 100.15 & 100.25 & 99.69 & 100.12 & 100.2 & 100.11 & 100.43 & 100.65 & 101.03 \\
\hline \multicolumn{11}{|c|}{ Trace Elements (ppm) } \\
\hline $\mathrm{Ni}$ & 60 & 47 & 44 & 64 & 84 & 89 & 82 & 44 & 51 & 59 \\
\hline $\mathrm{Cr}$ & 229 & 143 & 150 & 247 & 218 & 222 & 212 & 157 & 231 & 236 \\
\hline $\mathrm{Zn}$ & 68 & 71 & 64 & 88 & 74 & 71 & 68 & 68 & 74 & 71 \\
\hline $\mathrm{Ga}$ & 21 & 15 & 18 & 20 & 18 & 20 & 18 & 19 & 19 & 19 \\
\hline $\mathrm{Rb}$ & 1.3 & 1.6 & 1.8 & 4 & $<1$ & $<1$ & $<1$ & $<1$ & $<1$ & $<1$ \\
\hline $\mathrm{Sr}$ & 109 & 92 & 94 & 115 & 94 & 95 & 96 & 97 & 111 & 118 \\
\hline $\mathrm{Y}$ & 41 & 30 & 30 & 42 & 30 & 31 & 31 & 30 & 40 & 40 \\
\hline $\mathrm{Zr}$ & 111 & 72 & 68 & 114 & 76 & 78 & 76 & 66 & 110 & 111 \\
\hline $\mathrm{Nb}$ & 3 & 3 & 1 & 2 & 2 & 2 & 2 & 1 & 3 & 3 \\
\hline $\mathrm{Ba}$ & 29 & 13 & 17 & - & 15 & 23 & 16 & 17 & 32 & 20 \\
\hline $\mathrm{La}$ & 6 & 3 & 2 & 4 & 3 & 3 & 5 & 4 & 5 & 5 \\
\hline $\mathrm{Ce}$ & 14 & 13 & 10 & 12 & 8 & 7 & 11 & 9 & 12 & 15 \\
\hline Nd & 12 & 10 & 9 & 13 & 9 & 8 & 9 & 8 & 12 & 11 \\
\hline \multicolumn{11}{|l|}{ Selected Ratios } \\
\hline $\mathrm{FeO}^{*} / \mathrm{MgO}$ & 1.21 & 1.25 & 1.23 & 1.29 & 1.29 & 1.32 & 1.26 & 1.23 & 1.29 & 1.27 \\
\hline $\mathrm{Zr} / \mathrm{Nb}$ & 37 & 24 & 68 & 57 & 38 & 39 & 38 & 66 & 37 & 37 \\
\hline $\mathrm{Ti} / \mathrm{Zr}$ & 99 & 108 & 119 & 100 & 114 & 111 & 115 & 122 & 105 & 99 \\
\hline $\mathrm{Ba} / \mathrm{Zr}$ & 0.26 & 0.18 & 0.25 & - & 0.20 & 0.29 & 0.21 & 0.26 & 0.29 & 0.18 \\
\hline $\mathrm{K} / \mathrm{Rb}$ & 513 & 312 & 139 & 833 & $>400$ & $>400$ & $>500$ & $>550$ & $>750$ & $>500$ \\
\hline $\mathrm{Ba} / \mathrm{Sr}$ & 0.27 & 0.14 & 0.18 & - & 0.16 & 0.24 & 0.17 & 0.18 & 0.29 & 0.17 \\
\hline$(\mathrm{Ce} / \mathrm{Y})_{\mathrm{N}}$ & 0.8 & 0.9 & 0.8 & 0.9 & 0.7 & 0.6 & 0.9 & 0,7 & 0.7 & 0.9 \\
\hline \multicolumn{11}{|c|}{ CIPW Norms (\%) } \\
\hline Or & 0.5 & 0.36 & 0.2 & 2.4 & 0.3 & 0.3 & 0.4 & 0.4 & 0.5 & 0.4 \\
\hline $\mathrm{Ab}$ & 21.3 & 19.2 & 20.7 & 20.0 & 19.9 & 21.4 & 22.1 & 21.5 & 22.6 & 22.9 \\
\hline An & 29.5 & 30.3 & 31.3 & 28.7 & 30.3 & 30.4 & 30.2 & 29.8 & 29.0 & 29.9 \\
\hline $\mathrm{Di}$ & 19.2 & 23.4 & 23.4 & 23.0 & 23.4 & 23.5 & 23.2 & 24.0 & 21.8 & 22.4 \\
\hline Hy & 20.4 & 19.2 & 13.5 & 18.0 & 14.7 & 11.3 & 11.8 & 11.9 & 13.4 & 12.3 \\
\hline ol & 1.9 & 1.7 & 5.3 & 0.3 & 5.3 & 7.4 & 6.5 & 7.0 & 5.7 & 6.2 \\
\hline Mt & 1.9 & 1.9 & 1.8 & 1.8 & 2.0 & 2.0 & 1.9 & 1.9 & 1.9 & 1.9 \\
\hline Il & 3.5 & 2.5 & 2.6 & 3.6 & 2.7 & 2.8 & 2.8 & 2.5 & 3.7 & 3.5 \\
\hline Ap & 0.5 & 0.3 & 0.3 & 0.4 & 0.2 & 0.2 & 0.3 & 0.3 & 0.5 & 0.4 \\
\hline
\end{tabular}

Note: $\mathrm{tFe}_{2} \mathrm{O}_{3}=$ total iron as $\mathrm{Fe}_{2} \mathrm{O}_{3} ; \mathrm{LOI}=$ loss on ignition; $\mathrm{FeO} *$ total iron as $\mathrm{FeO} ;(\mathrm{Ce} / \mathrm{Y})_{\mathrm{N}}=\mathrm{Chondrite-normalized} \mathrm{Ce/Y} \mathrm{ratio.} \mathrm{CIPW} \mathrm{Norms} \mathrm{de-}$ termined assuming an $\mathrm{Fe}_{2} \mathrm{O}_{3} / \mathrm{FeO}$ ratio of 0.15 .

richment in HYG-elements in Type I without dramatically increasing the $\mathrm{FeO} * / \mathrm{MgO}$ ratio and total iron content, and reducing the $\mathrm{MgO}$ and $\mathrm{Ni}$ content, unless plagioclase formed a large proportion of the cumulate phase. This would be expected to reduce the $\mathrm{Sr}$ content and possibly produce negative $\mathrm{Eu}$ anomalies in the Chemical Type I basalts, neither of which is observed. In other words, there is not a good agreement between major and HYG-element modelling: the trace element data require much greater degrees of crystal fractionation than the major element data, although in the absence of mineral data it is not possible to be more quantitative.
Similar problems were encountered by Mattey and Muir (1980) when considering the petrogenesis of the moderately evolved basalts recovered during Leg 54 from the Galapagos Spreading Center. They suggest that their moderately evolved basalts, which are approximate equivalents of Chemical Type I of this study, were formed by mixing of ferrobasalt ( $>14 \%$ total iron) with more primitive $\mathrm{N}$-type basalt (?equivalent to Chemical Type II of this study) in an open magma chamber of the type envisaged by O'Hara (1977). No ferrobasalts were recovered during Leg 65 but it is proposed that Chemical Types I and II could be derived from the same magma chamber during open-system fractional crystallization. 
This mechanism has the advantage of strongly enriching the HYG elements while the major element compositions are buffered by the melt (O'Hara, 1977; Dungan and Rhodes, 1978). However, detailed modelling is required to verify this suggestion.

As previously stated, the analyses and biaxial plots of precisely measured immobile HYG and more-HYG elements, particularly $\mathrm{La}, \mathrm{Ti}, \mathrm{Zr}, \mathrm{Y}$, and $\mathrm{Yb}$, reveal that the more-HYG/HYG element ratios (e.g., La/Yb) increase with increasing fractionation (e.g., Table 3 ) and that the HYG/HYG element ratios vary systematically with increasing fractionation. Thus, the $\mathrm{Zr} / \mathrm{Y}$ and $\mathrm{Zr} / \mathrm{Ti}$ ratios increase with increasing $\mathrm{Zr}$ content (Figs. 6 and 7). Similar variations have been observed in the basalts recovered from the Reykjanes Ridge during Leg 49 (Tarney et al., 1979), in back-arc basin basalts (Saunders and Tarney, 1979), and in many other basalt suites. Perhaps the most satisfactory mechanism for increasing the $\mathrm{Zr} / \mathrm{Y}, \mathrm{Zr} / \mathrm{Ti}$, and $\mathrm{La} / \mathrm{Yb}$ ratios is the removal of clinopyroxene from the melt during either partial melting or fractional crystallization. This is because clinopyroxene has relatively high partition coefficient values for the heavy rare earth elements, Y, and Ti (Schnetzler and Philpotts, 1970; Pearce and Norry, 1979; Sun et al., 1979). In theory, closed-system fractional crystallization can adequately account for the increases in the $\mathrm{Zr} / \mathrm{Ti}, \mathrm{Zr} / \mathrm{Y}$, and $\mathrm{La} / \mathrm{Yb}$ ratios throughout the Site 482 basalts, provided that at least $50 \%$ of the residue consists of clinopyroxene. However, open system fractionation (O'Hara, 1977) is a more effective mechanism for producing changes in the HYG/HYG element ratios (e.g., Tarney et al., 1980) and, from previous arguments, may provide a more practical solution to the present problem. Indeed it is difficult to see how a simple closed-system magma chamber could produce a succession of intercalated Type I basalts (with high $\mathrm{Zr} / \mathrm{Ti}, \mathrm{Zr} / \mathrm{Y}$ ratios) and Type II basalts (with low $\mathrm{Zr} / \mathrm{Ti}, \mathrm{Zr} / \mathrm{Y}$ ratios).

Finally, it is necessary to attempt to evaluate the incompatible element ratios of the source of the Site 482 basalts. This is easier for the more-HYG elements, which by definition have very low bulk distribution coefficients, than it is for the HYG elements (see discussion by Bougault and Treuil, 1980). Thus, from the data given in Tables 2 and 3, the mantle source probably had a $\mathrm{La} / \mathrm{Ta}$ ratio of 25 (although this is based on a single $\mathrm{Ta}$ determination), a $\mathrm{La} / \mathrm{Th}$ ratio of 2.4 , and $\mathrm{a} \mathrm{Ba} / \mathrm{La}$ ratio of about 7. These values assume that the bulk distribution coefficients of $\mathrm{Th}, \mathrm{Ta}, \mathrm{Ba}$, and $\mathrm{La}$ approach zero during the relatively high degree of partial melting required to produce ocean ridge basalts ( $\sim 15$ to $20 \%$ at 1.5 to $1.3 \mathrm{wt} . \% \mathrm{TiO}_{2}$ : Sun et al., 1979). It is likely that the $D$ values for $\mathrm{Nb}, \mathrm{Zr}, \mathrm{Hf}$, and $\mathrm{Sm}$ will also be very low; thus the measured ratios of Th/Hf $(\sim 0.04), \mathrm{La}_{\mathrm{N}} /$ $\mathrm{Sm}_{\mathrm{N}}(\sim 0.5), \mathrm{Nb} / \mathrm{Zr}(\sim 0.02)$, and $\mathrm{Ba} / \mathrm{Zr}(\sim 0.22)$ probably reflect source ratios or at least give maximum source ratio values. It is more difficult to ascertain the HYG/ HYG element ratios of the source, because of the rate at which these ratios change during fractionation. The maximum values may be estimated from the least fractionated samples recovered at Site 482: for example $\mathrm{Zr}$ / $\mathrm{Ti}<0.008$ (which is approximately chondritic and low- er than the source ratios for N-type MORB calculated by Sun et al., 1979 and Tarney et al., 1980 ( 0.0091 and 0.0097 , respectively)); $\mathrm{Zr} / \mathrm{Y}<2.3$ (2.8 in Tarney et al., $1980)$; and $\mathrm{La}_{\mathrm{N}} / \mathrm{Yb}_{\mathrm{N}}<0.39(\sim 0.6$ in Tarney et al., 1980). These values all suggest severe relative depletion in the more-HYG elements and in several of the HYG elements.

\section{SITE 483}

The primary scientific goal at Site $483\left(22^{\circ} 53.0^{\prime} \mathrm{N}\right.$, $108^{\circ} 44.9^{\prime} \mathrm{W}, 3070 \mathrm{~m}$ water depth) was to complete the transect from the EPR to the continental margin off Baja California. Site 483 was located approximately $52 \mathrm{~km}$ west of the EPR, and about $25 \mathrm{~km}$ east of the base of the Baja California continental slope, on a topographically smooth region of seafloor (Fig. 1). Four holes were drilled; although three of these (483, 483B, and 483C) resulted in the successful recovery of basalts, no samples from Hole $483 \mathrm{C}$ were analyzed during the present study.

\section{Holes 483 and 483B}

The lithologies recovered in Holes 483 and 483B are summarized in Figure 10 using the same lithologic units as those recognized by the shipboard party in the Site 483 report. Clearly, there is considerable correlation between holes, and it is possible to match most of the units in Hole 483 with those from the upper part of Hole 483B. Accordingly, emphasis will be placed on the basalts from Hole 483B.

Nine major lithological units were recognized in Hole 483B by the shipboard party. The upper four units are massive aphyric cooling units, except for Unit 1 which contains 5 modal $\%$ plagioclase, 2 modal $\%$ olivine, and traces of clinopyroxene phenocrysts. Units 1 through 4 are separated from each other and from Unit 5 by sedimentary intercalations. An igneous body was drilled between Units 4 and 5 in the interval from 155 to 160 meters sub-bottom. No basalt was recovered from this unit, but it probably corresponds to Unit 5 in Hole 483 .

Unit 5 comprises a series of approximately 16 pillows of porphyritic basalt, of which the upper few meters were not recovered. The phenocryst content is generally 5 to 10 modal $\%$ with plagioclase $>$ olivine $>$ clinopyrox- ene. The phenocrysts are more variable in the upper part of the unit (at least one cooling unit is aphyric), and their abundance is also variable within single pillows. Beneath Unit 5 is a sequence of four massive cooling units (Unit 6) of very sparsely porphyritic basalt (aphyric to approximately $7 \%$ phenocrysts, with plagioclase dominant over olivine and with rare clinopyroxene). The shipboard party considers these cooling units to be flows rather than sills.

Unit 7 consists of about 30 pillows of porphyritic basalt. The basalt contains more phenocrysts than the basalt from Unit 5 (10 to 15 modal \%), with plagioclase predominating over clinopyroxene and olivine. Unit 7 overlies Unit 8, a sequence of three (or possibly four) massive basalt flows. The phenocrysts range from 5 to 10 modal $\%$ with plagioclase $>$ clinopyroxene $>$ olivine. Unit 9, which extends from 251.6 meters sub-bottom to the base of the hole, consists of 23 pillows of moderately 

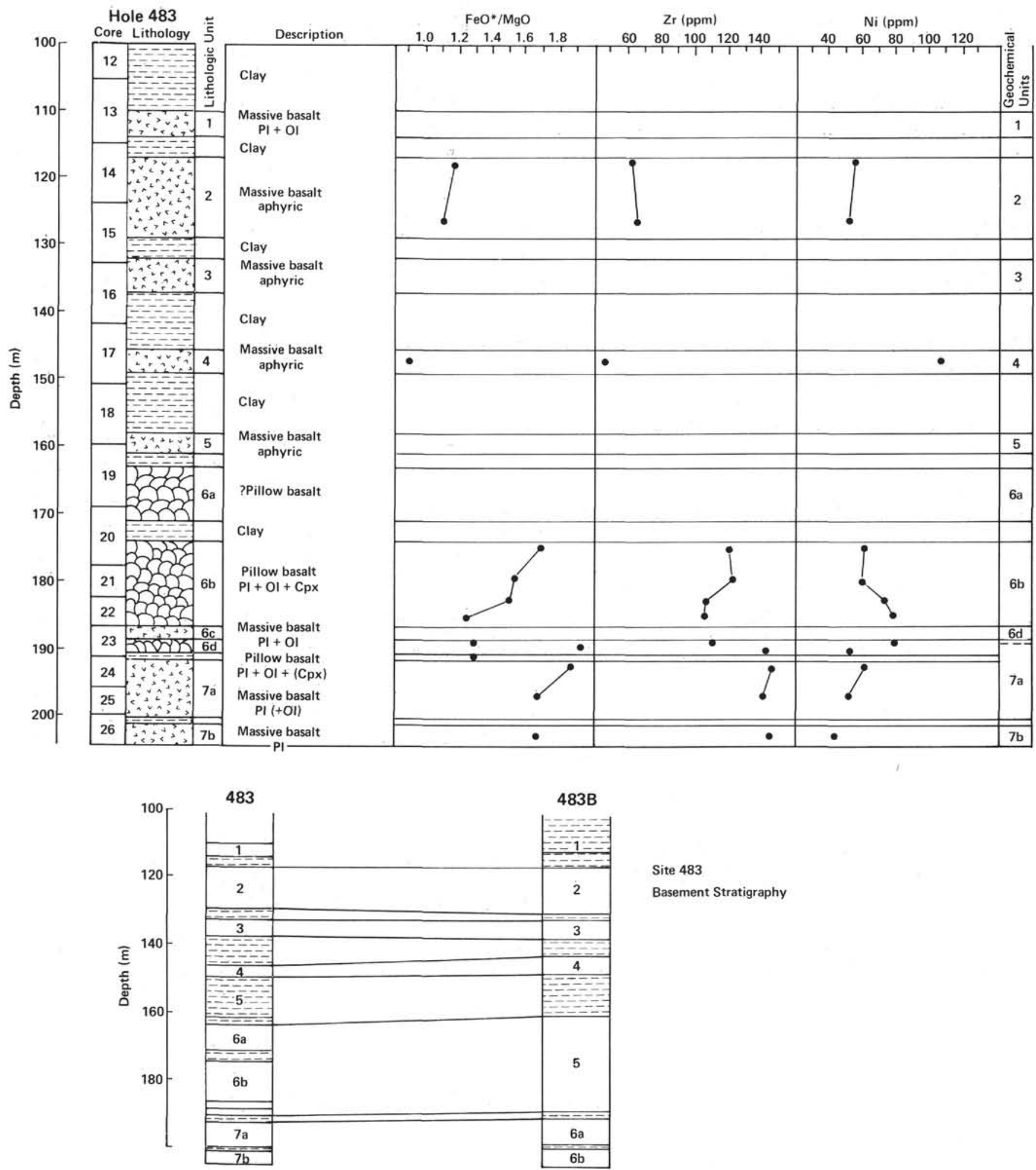

Site 483

Basement Stratigraphy

Figure 10. Lithology, mineralogy, and selected geochemical parameters vs. depth in Holes 483 and $483 \mathrm{~B}$. (FeO* represents total iron. Inset shows postulated correlation of stratigraphy between holes.) 


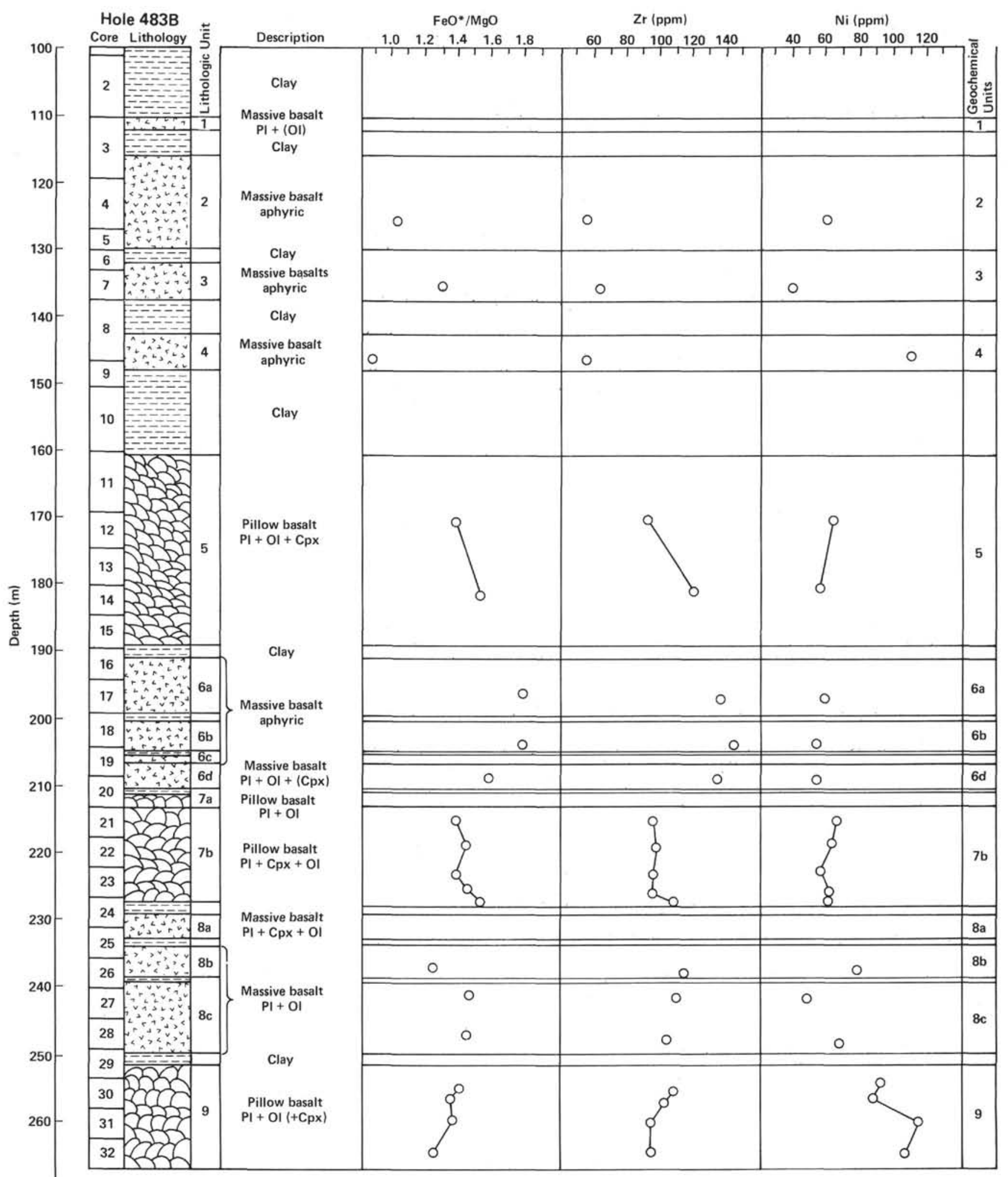

$270^{\mathrm{L}}$

Figure 10. (Continued). 
porphyritic ( 8 to 12 modal $\%$ ) basalt, with plagioclase predominating over olivine and with minor, but variable, quantities of clinopyroxene phenocrysts. Note that clinopyroxene is more abundant than olivine in Units 7 and 8 of Hole 483B.

The basalts exhibit variable degrees of alteration, but in general the alteration products (smectites, carbonates, sulfides, and zeolites) are characteristic of lowtemperature interaction between basalt and seawater. Unlike the basalts from Site 482, those recovered from Site 483 contain sulfides throughout most of the section.
This is probably related to the frequent sedimentary intercalations detected in Holes 483 and 483B. The degree of alteration appears to increase with depth, although the metamorphic grade is generally constant throughout the section recovered. In general, the massive units tend to be less altered than the fractured pillow sequences.

Major and trace element analyses of the basalt recovered at Site 483 are presented in Tables 5, 6, and 7. All of the basalts are subalkaline tholeiites (Fig. 3) and in general terms their chemistry resembles that of the basalts from Site 482 . They tend, for example, to dis-

Table 5. X-ray fluorescence analyses of basalts, Hole 483 .

\begin{tabular}{|c|c|c|c|c|c|c|c|c|c|c|c|c|}
\hline $\begin{array}{c}\text { Sample } \\
\text { (level in cm) }\end{array}$ & $\begin{array}{c}14-1, \\
23\end{array}$ & $\begin{array}{c}15-2, \\
1\end{array}$ & $\begin{array}{c}17-2, \\
76\end{array}$ & $\begin{array}{c}20-1 \\
59\end{array}$ & $\begin{array}{c}21-1 \\
63\end{array}$ & $\begin{array}{c}22-1 \\
42\end{array}$ & $\begin{array}{c}22-3, \\
27\end{array}$ & $\begin{array}{c}23-2, \\
76\end{array}$ & $\begin{array}{c}23-2 \\
124\end{array}$ & $\begin{array}{c}24-1, \\
96\end{array}$ & $\begin{array}{c}25-1, \\
25\end{array}$ & $\begin{array}{c}26-3, \\
120\end{array}$ \\
\hline Unit & 2 & 2 & 4 & $6 \mathrm{~b}$ & $6 \mathrm{~b}$ & $6 \mathrm{~b}$ & $6 \mathrm{~b}$ & $6 d$ & $7 a$ & $7 a$ & $7 a$ & $7 b$ \\
\hline \multicolumn{13}{|c|}{ Major Elements (wt.\%) } \\
\hline $\mathrm{SiO}_{2}$ & 49.89 & 49.54 & 48.48 & 48.98 & 48.60 & 49.28 & 49.84 & 49.15 & 49.00 & 48.40 & $49: 00$ & 49.41 \\
\hline $\mathrm{TiO}_{2}$ & 1.29 & 1.24 & 0.91 & 1.99 & 2.03 & 1.80 & 1.84 & 1.82 & 2.22 & 2.41 & 2.35 & 2.30 \\
\hline $\mathrm{Al}_{2} \mathrm{O}_{3}$ & 15.10 & 16.03 & 16.36 & 14.87 & 15.29 & 14.75 & 15.27 & 15.51 & 14.53 & 14.53 & 14.71 & 14.73 \\
\hline $\mathrm{tFe}_{2} \mathrm{O}_{3}$ & 10.04 & 9.68 & 9.30 & 12.69 & 12.52 & 11.87 & 10.68 & 10.95 & 13.36 & 13.67 & 12.79 & 12.60 \\
\hline $\mathrm{MnO}$ & 0.18 & 0.16 & 0.15 & 0.20 & 0.21 & 0.20 & 0.18 & 0.20 & 0.20 & 0.22 & 0.18 & 0.18 \\
\hline $\mathrm{MgO}$ & 7.8 & 7.6 & 9.3 & 6.8 & 7.4 & 7.1 & 7.8 & 7.7 & 6.3 & 6.6 & 6.9 & 6.8 \\
\hline $\mathrm{CaO}$ & 11.75 & 12.17 & 12.45 & 11.93 & 12.09 & 12.03 & 12.05 & 12.10 & 11.63 & 11.50 & 11.54 & 11.18 \\
\hline $\mathrm{Na}_{2} \mathrm{O}$ & 2.58 & 2.60 & 2.00 & 2.55 & 2.61 & 2.49 & 2.72 & 2.75 & 2.54 & 2.64 & 2.90 & 2.79 \\
\hline $\mathrm{K}_{2} \mathrm{O}$ & 0.09 & 0.05 & 0.03 & 0.12 & 0.08 & 0.09 & 0.06 & 0.09 & 0.12 & 0.12 & 0.08 & 0.11 \\
\hline $\mathrm{P}_{2} \mathrm{O}_{5}$ & 0.12 & 0.12 & 0.07 & 0.14 & 0.16 & 0.13 & 0.14 & 0.16 & 0.14 & 0.20 & 0.22 & 0.25 \\
\hline LOI & - & - & 1.46 & - & +0.14 & - & - & - & - & 0.06 & - & - \\
\hline Total & 98.79 & 99.19 & 100.50 & 100.27 & 100.80 & 99.74 & 100.53 & 100.38 & 100.04 & 100.24 & 100.67 & 100.35 \\
\hline
\end{tabular}

Trace Elements (ppm)

$\begin{array}{lcc}\mathrm{Ni} & 57 & 53 \\ \mathrm{Cr} & 281 & 306 \\ \mathrm{Zn} & 57 & 57 \\ \mathrm{Ga} & 20 & 20 \\ \mathrm{Rb} & 0.1 & 0.1 \\ \mathrm{Sr} & 118 & 115 \\ \mathrm{Y} & 26 & 27 \\ \mathrm{Zr} & 63 & 65 \\ \mathrm{Nb} & <1 & 2 \\ \mathrm{Ba} & 17 & 15 \\ \mathrm{La} & 3 & 3 \\ \mathrm{Ce} & 12 & 9 \\ \mathrm{Nd} & 8 & 7\end{array}$

$\begin{array}{rrrr}107 & 61 & 60 & 72 \\ 275 & 175 & 175 & 223 \\ 52 & 83 & - & 81 \\ 18 & 21 & - & 20 \\ <1 & 2 & - & 2.5 \\ 194 & 104 & - & 103 \\ 22 & 42 & - & 40 \\ 46 & 120 & 119 & 109 \\ <1 & 3 & 4 & 3 \\ 18 & 15 & - & 26 \\ 2 & 5 & 5 & 5 \\ 8 & 17 & 17 & 13 \\ 6 & 13 & 13 & 11\end{array}$

$\begin{array}{rrc}78 & 78 & 51 \\ 249 & 225 & 140 \\ 78 & 81 & 95 \\ 23 & 21 & 24 \\ <1 & <1 & 1.5 \\ 109 & 107 & 108 \\ 38 & 40 & 49 \\ 107 & 110 & 141 \\ 3 & 3 & 5 \\ 19 & 22 & 35 \\ 5 & 5 & 6 \\ 15 & 17 & 12 \\ 12 & 13 & 13\end{array}$

$\begin{array}{rrr}61 & 51 & 44 \\ 140 & 139 & 153 \\ 95 & 87 & 84 \\ 22 & 23 & 21 \\ <1 & <1 & <1 \\ 109 & 107 & 108 \\ 49 & 47 & 50 \\ 144 & 140 & 143 \\ 4 & 3 & 4 \\ 37 & 35 & 30 \\ 7 & 7 & 7 \\ 18 & 15 & 15 \\ 15 & 15 & 15\end{array}$

Selected Ratios

$\begin{array}{lccccc}\mathrm{FeO} * / \mathrm{MgO} & 1.17 & 1.15 & 0.90 & 1.68 & 1.53 \\ \mathrm{Zr} / \mathrm{Nb} & >63 & 33 & >46 & 40 & 30 \\ \mathrm{Ti} / \mathrm{Zr} & 123 & 114 & 119 & 99 & 102 \\ \mathrm{Ba} / \mathrm{Zr} & 0.27 & 0.23 & 0.39 & 0.13 & - \\ \mathrm{K} / \mathrm{Rb} & >750 & >400 & >250 & 500 & - \\ \mathrm{Ba} / \mathrm{Sr} & 0.14 & 0.13 & 0.09 & 0.14 & - \\ (\mathrm{Ce} / \mathrm{Y})_{\mathrm{N}} & 1.0 & 0.7 & 0.8 & 0.9 & -\end{array}$

$\begin{array}{cc}1.50 & 1.24 \\ 36 & 36 \\ 99 & 103 \\ 0.24 & 0.18 \\ 300 & >500 \\ 0.25 & 0.17 \\ 0.7 & 0.9\end{array}$
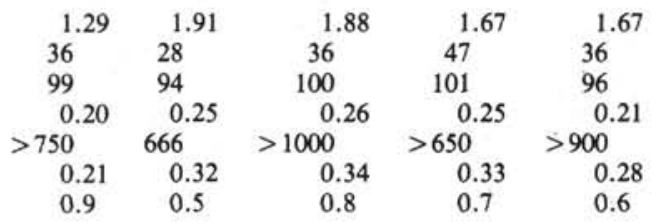

CIPW Norms $(\%)$

\begin{tabular}{|c|c|c|c|c|c|c|c|c|c|c|c|c|}
\hline Or & 0.5 & 0.3 & 0.2 & 0.7 & 0.5 & 0.5 & 0.4 & 0.5 & 0.7 & 0.7 & 0.5 & 0.7 \\
\hline $\mathrm{Ab}$ & 21.8 & 22.0 & 16.9 & 21.6 & 22.1 & 21.1 & 23.0 & 23.3 & 21.5 & 22.3 & 24.5 & 23.6 \\
\hline An & 29.4 & 31.9 & 35.6 & 28.8 & 29.8 & 28.8 & 29.3 & 29.7 & 27.9 & 27.4 & 26.9 & 27.3 \\
\hline Di & 22.9 & 22.5 & 20.8 & 24.3 & 23.9 & 24.6 & 24.1 & 23.9 & 23.9 & 23.4 & 23.8 & 21.8 \\
\hline $\mathrm{Hy}$ & 15.7 & 11.8 & 12.7 & 12.7 & 7.9 & 14.6 & 11.4 & 7.4 & 16.2 & 12.3 & 9.5 & 15.8 \\
\hline OI & 3.1 & 5.5 & 8.5 & 4.9 & 9.3 & 3.3 & 5.8 & 8.9 & 1.9 & 5.5 & 7.2 & 2.9 \\
\hline Mt & 1.7 & 1.7 & 1.6 & 2.2 & 2.2 & 2.0 & 1.8 & 1.9 & 2.3 & 2.4 & 2.2 & 2.2 \\
\hline Il & 2.5 & 2.4 & 1.7 & 3.8 & 3.9 & 3.4 & 3.5 & 3.5 & 4.2 & 4.6 & 4.5 & 4.4 \\
\hline Ap & 0.3 & 0.3 & 0.2 & 0.3 & 0.4 & 0.3 & 0.3 & 0.4 & 0.3 & 0.5 & 0.5 & 0.6 \\
\hline
\end{tabular}

Note: $\mathrm{tFe}_{2} \mathrm{O}_{3}=$ total iron as $\mathrm{Fe}_{2} \mathrm{O}_{3} ; \mathrm{LOI}=$ loss on ignition: $\mathrm{FeO}^{*}=$ total iron as $\mathrm{FeO} ;(\mathrm{Ce} / \mathrm{Y})_{\mathrm{N}}=\mathrm{Chondrite-normalized} \mathrm{Ce} / \mathrm{Y}$ ratio; $\mathrm{CIPW}$ Norms determined assuming an $\mathrm{Fe}_{2} \mathrm{O}_{3} / \mathrm{FeO}$ ratio of 0.15 . 
Table 6. X-ray fluorescence analyses of basalts, Hole 483B.

\begin{tabular}{|c|c|c|c|c|c|c|c|c|c|c|c|c|c|c|c|c|c|c|c|c|}
\hline $\begin{array}{c}\text { Sample } \\
\text { (level in } \mathrm{cm} \text { ) }\end{array}$ & $\begin{array}{l}4-5 \\
100\end{array}$ & $\begin{array}{c}7-3, \\
59\end{array}$ & $\begin{array}{c}8-3, \\
2\end{array}$ & $\begin{array}{c}12-1 \\
4\end{array}$ & $\begin{array}{c}14-1, \\
68\end{array}$ & $\begin{array}{c}17-1, \\
40\end{array}$ & $\begin{array}{c}19-1 \\
2\end{array}$ & $\begin{array}{c}20-2, \\
32\end{array}$ & $\begin{array}{c}21-2 \\
31\end{array}$ & $\begin{array}{l}22-2, \\
32\end{array}$ & $\begin{array}{c}23-1, \\
16\end{array}$ & $\begin{array}{c}23-3, \\
47\end{array}$ & $\begin{array}{c}24-1, \\
91\end{array}$ & $\begin{array}{l}26-1, \\
117\end{array}$ & $\begin{array}{c}27-2 \\
76\end{array}$ & $\begin{array}{c}28-1, \\
42\end{array}$ & $\begin{array}{c}30-1, \\
65\end{array}$ & $\begin{array}{c}30-3, \\
30\end{array}$ & $\begin{array}{c}31-2 \\
75\end{array}$ & $\begin{array}{c}32-2, \\
39\end{array}$ \\
\hline Unit & 2 & 3 & 4 & 5 & 5 & $6 a$ & $6 \mathrm{~b}$ & $6 \mathrm{~d}$ & $7 \mathrm{~b}$ & $7 \mathrm{~b}$ & $7 \mathrm{~b}$ & $7 b$ & $7 \mathrm{~b}$ & $8 \mathrm{~b}$ & $8 \mathrm{c}$ & $8 \mathrm{c}$ & 9 & 9 & 9 & 9 \\
\hline \multicolumn{21}{|c|}{ Major Elements (wt.\%) } \\
\hline $\mathrm{SiO}_{2}$ & 47.61 & 48.47 & 48.3 & 48.02 & 49.21 & 48.76 & 49.13 & 49.21 & 48.69 & 48.82 & 49.09 & 48.68 & 48.62 & 49.38 & 49.41 & 49.57 & 48.58 & 49.22 & 49.29 & 49.39 \\
\hline $\mathrm{TiO}_{2}$ & 1.19 & 1.36 & 1.06 & 1.71 & 2.02 & 2.20 & 2.39 & 2.21 & 1.80 & 1.78 & 1.79 & 1.80 & 2.04 & 2.10 & 1.93 & 1.92 & 1.99 & 1.94 & 1.80 & 1.75 \\
\hline $\mathrm{Al}_{2} \mathrm{O}_{3}$ & 15.54 & 15.48 & 16.22 & 15.14 & 15.23 & 14.85 & 14.71 & 14.78 & 14.26 & 14.56 & 14.66 & 14.97 & 14.86 & 14.93 & 15.05 & 14.46 & 15.22 & 15.12 & 14.90 & 15.20 \\
\hline $\mathrm{tFe}_{2} \mathrm{O}_{3}$ & 9.89 & 10.85 & 9.52 & 11.85 & 12.07 & 13.26 & 12.72 & 12.48 & 11.85 & 11.89 & 12.01 & 11.91 & 12.22 & 10.36 & 11.74 & 12.15 & 11.46 & 11.38 & 11.52 & 10.83 \\
\hline $\mathrm{MnO}$ & 0.17 & 0.17 & 0.15 & 0.19 & 0.18 & 0.20 & 0.19 & 0.19 & 0.22 & 0.18 & 0.21 & 0.18 & 0.21 & 0.17 & 0.17 & 0.16 & 0.20 & 0.20 & 0.21 & 0.20 \\
\hline $\mathrm{MgO}$ & 8.8 & 7.5 & 9.6 & 7.8 & 7.2 & 6.7 & 6.4 & 7.1 & 7.7 & 7.5 & 7.8 & 7.5 & 7.3 & 7.6 & 7.3 & 7.6 & 7.4 & 7.7 & 7.8 & 7.8 \\
\hline $\mathrm{CaO}$ & 11.95 & 12.32 & 11.90 & 12.16 & 11.67 & 11.66 & 11.72 & 11.15 & 12.04 & 12.23 & 12.19 & 12.03 & 12.04 & 11.94 & 11.44 & 11.45 & 12.07 & 12.05 & 12.01 & 12.18 \\
\hline $\mathrm{Na}_{2} \mathrm{O}$ & 2.52 & 2.78 & 2.11 & 2.55 & 2.78 & 2.61 & 2.76 & 2.80 & 2.44 & 2.72 & 2.52 & 2.55 & 2.61 & 2.78 & 2.71 & 2.56 & 2.61 & 2.60 & 2.58 & 2.63 \\
\hline $\mathrm{K}_{2} \mathrm{O}$ & 0.08 & 0.05 & 0.05 & 0.07 & 0.09 & 0.15 & 0.05 & 0.12 & 0.08 & 0.08 & 0.05 & 0.05 & 0.06 & 0.13 & 0.11 & 0.10 & 0.09 & 0.07 & 0.22 & 0.06 \\
\hline $\mathrm{P}_{2} \mathrm{O}_{5}$ & 0.11 & 0.11 & 0.08 & 0.11 & 0.19 & 0.15 & 0.20 & 0.24 & 0.10 & 0.13 & 0.12 & 0.12 & 0.15 & 0.20 & 0.19 & 0.15 & 0.15 & 0.14 & 0.13 & 0.12 \\
\hline LOI & 0.49 & - & 1.22 & - & +0.01 & - & 0.43 & - & - & - & 0.02 & - & - & - & +0.21 & 0.13 & - & - & - & - \\
\hline Total & 98.24 & 99.09 & 100.25 & 99.60 & 100.58 & 100.54 & 100.73 & 100.28 & 99.13 & 99.89 & 100.46 & 99.74 & 100.11 & 99.59 & 99.64 & 100.27 & 99.72 & 100.42 & 100.41 & 100.16 \\
\hline \multicolumn{21}{|c|}{ Trace Elements (ppm) } \\
\hline $\mathrm{Ni}$ & 60 & 40 & 111 & 64 & 55 & 58 & 54 & 54 & 65 & 63 & 56 & 60 & 60 & 78 & 48 & 68 & 90 & 87 & 114 & 106 \\
\hline $\mathrm{Cr}$ & 294 & 191 & 246 & 176 & 165 & 140 & 135 & 138 & 181 & 176 & 170 & 166 & 162 & 182 & 135 & 173 & 211 & 233 & 271 & 289 \\
\hline $\mathrm{Zn}$ & 56 & 63 & 62 & 76 & 84 & 90 & 100 & 87 & 83 & 76 & 79 & 74 & 85 & 84 & 79 & 79 & 79 & 82 & 79 & 77 \\
\hline $\mathrm{Ga}$ & 20 & 22 & 16 & 20 & 21 & 23 & 23 & 22 & 22 & 18 & 19 & 18 & 22 & 22 & 21 & 16 & 20 & 21 & 22 & 21 \\
\hline $\mathrm{Rb}$ & 1.3 & 1.4 & 1.5 & 1.3 & $<1$ & $<1$ & 1.5 & $<1$ & 1 & $<1$ & $<1$ & $<1$ & $<1$ & 1 & $<1$ & 1.8 & $<1$ & $<1$ & 2 & $<1$ \\
\hline $\mathrm{Sr}$ & 111 & 141 & 132 & 115 & 104 & 105 & 115 & 108 & 110 & 111 & 110 & 111 & 116 & 121 & 113 & 106 & 117 & 116 & 116 & 122 \\
\hline $\mathrm{Y}$ & 25 & 30 & 24 & 36 & 45 & 48 & 51 & 47 & 38 & 36 & 37 & 36 & 39 & 41 & 39 & 37 & 38 & 40 & 35 & 35 \\
\hline $\mathrm{Zr}$ & 57 & 63 & 57 & 91 & 120 & 137 & 143 & 133 & 96 & 98 & 97 & 95 & 109 & 113 & 109 & 104 & 107 & 102 & 93 & 93 \\
\hline $\mathrm{Nb}$ & 1 & $<1$ & $<1$ & 1 & 3 & 3 & 3 & 3 & 2 & 2 & $>1$ & 3 & 2 & 2 & 2 & 2 & $<1$ & $<1$ & 2 & 2 \\
\hline $\mathrm{Ba}$ & 16 & 15 & 23 & 19 & 24 & 33 & 31 & 41 & 31 & 28 & 18 & 25 & 30 & 34 & 25 & 21 & 28 & 32 & 21 & 26 \\
\hline $\mathrm{La}$ & 3 & 3 & 2 & 5 & 6 & 12 & 8 & 7 & 4 & 5 & 4 & 4 & 5 & 6 & 6 & 5 & 6 & 7 & 5 & 5 \\
\hline $\mathrm{Ce}$ & 10 & 9 & 6 & 12 & 16 & 17 & 18 & 16 & 10 & 10 & 10 & 9 & 12 & 14 & 15 & 14 & 14 & 13 & 15 & 11 \\
\hline $\mathrm{Nd}$ & 8 & 9 & 7 & 12 & 13 & 13 & 15 & 17 & 9 & 10 & 10 & $=10$ & 12 & 12 & 13 & 12 & 12 & 10 & 12 & 10 \\
\hline \multicolumn{21}{|l|}{ Selected Ratios } \\
\hline $\mathrm{FeO} * / \mathrm{MgO}$ & 1.01 & 1.30 & 0.89 & 1.37 & 1.52 & 1.78 & 1.78 & 1.58 & 1.39 & 1.43 & 1.39 & 1.44 & 1.51 & 1.23 & 1.45 & 1.43 & 1.40 & 1.33 & 1.34 & 1.25 \\
\hline $\mathrm{Zr} / \mathrm{Nb}$ & 57 & $>63$ & $>57$ & 91 & 40 & 46 & 48 & 44 & 48 & 49 & $>97$ & 32 & 55 & 56 & 55 & 52 & $>100$ & $>100$ & 47 & 47 \\
\hline $\mathrm{Ti} / \mathrm{Zr}$ & 125 & 129 & 111 & 113 & 101 & 96 & 100 & 100 & 112 & 109 & 111 & 114 & 112 & 111 & 106 & 110 & 111 & 114 & 116 & 113 \\
\hline $\mathrm{Ba} / \mathrm{Zr}$ & 0.28 & 0.24 & 0.40 & 0.21 & 0.20 & 0.24 & 0.22 & 0.31 & 0.32 & 0.29 & 0.19 & 0.26 & 0.28 & 0.30 & 0.23 & 0.20 & 0.26 & 0.31 & 0.23 & 0.28 \\
\hline $\mathrm{K} / \mathrm{Rb}$ & 513 & 298 & 278 & 449 & $>750$ & $>1250$ & 278 & $>1000$ & 666 & $>666$ & $>400$ & $>400$ & $>500$ & $>1000$ & $>900$ & 465 & $>750$ & $>600$ & 917 & $>500$ \\
\hline $\mathrm{Ba} / \mathrm{Sr}$ & 0.14 & 0.11 & 0.17 & 0.16 & 0.23 & $0.3 \mathrm{t}$ & 0.27 & 0.38 & 0.28 & 0.25 & 0.16 & 0.23 & 0.26 & 0.28 & 0.22 & 0.20 & 0.23 & 0.28 & 0.18 & 0.21 \\
\hline$(\mathrm{Ce} / \mathrm{Y})_{\mathrm{N}}$ & 0.9 & 0.6 & 0.5 & 0.7 & 0.8 & 0.8 & 0.8 & 0.7 & 0.6 & 0.6 & 0.6 & 0.5 & 0.7 & 0.7 & 0.8 & 0.8 & 0.8 & 0.7 & 0.9 & 0.7 \\
\hline \multicolumn{21}{|c|}{ CIPW Norms (\%) } \\
\hline Or & 0.5 & 0.3 & 0. & 0.4 & 0.5 & 0.9 & 0.3 & 0.7 & 0.5 & 0.5 & 0.3 & 0.3 & 0.4 & 0.8 & 0.7 & 0.6 & 0.5 & 0.4 & 1.3 & 0.4 \\
\hline $\mathrm{Ab}$ & 21.3 & 23.5 & 17.9 & 21.6 & 23.5 & 22.1 & 23.4 & 23.7 & 20.6 & 23.0 & 21.3 & 21.6 & 22.1 & 23.5 & 22.9 & 21.7 & 22.1 & 22.0 & 21.8 & 22.3 \\
\hline An. & 30.9 & 29.6 & 34.6 & 29.7 & 28.8 & 28.4 & 27.6 & 27.4 & 27.7 & 27.3 & 28.5 & 29.3 & 28.7 & 27.9 & 28.6 & 27.7 & 29.5 & 29.4 & 28.4 & 29.5 \\
\hline $\mathrm{Di}$ & 22. & 25 . & 1 & 24 & 22 & 2 & 2 & 21 & 25.7 & 26.6 & 25.5 & 24.3 & 24.7 & 2 & 22 & 23 & 24 & 2 & 24.8 & 24.6 \\
\hline Hy & 4.1 & 3.1 & 12.1 & 5.5 & 10.6 & 11.9 & 13.5 & 13.8 & 12.1 & 6.3 & 10.7 & 10.4 & 9.5 & 10.2 & 13.9 & 16.5 & 9.0 & 11.0 & 9.6 & 10.2 \\
\hline oí & 13.5 & 11.7 & 10.1 & 11.3 & 6. & 5.8 & 3.2 & 5.1 & 5.8 & 9.4 & 7.3 & 7.2 & 7.5 & 5.7 & 4.8 & 3.5 & 7.5 & 6. & 7.8 & 6.9 \\
\hline Mt & 1.7 & 1.9 & 1.6 & 2.0 & 2.1 & 2.3 & 2.2 & 2.2 & 2.0 & 2.1 & 2.1 & 2.1 & 2.1 & 1.8 & 2.0 & 2.1 & 2.0 & 2. & 2.0 & 1.9 \\
\hline Il & 2.3 & 2.6 & 2.0 & 3.2 & 3.8 & 4.2 & 4.5 & 4.2 & 3.4 & 3.4 & 3.4 & 3.4 & 3.9 & 4.0 & 3.7 & 3.6 & 3.8 & 3.7 & 3.4 & 3.3 \\
\hline Ap & 0.3 & 0.3 & 0.2 & 0.3 & 0.4 & 0.3 & 0.5 & 0.6 & 0.2 & 0.3 & 0.3 & 0.3 & 0.3 & 0.5 & 0.4 & 0.3 & 0.4 & 0.3 & 0.3 & 0.3 \\
\hline
\end{tabular}

Note: $\mathrm{tFe}_{2} \mathrm{O}_{3}=$ total iron as $\mathrm{Fe}_{2} \mathrm{O}_{3} ; \mathrm{LOI}=$ loss on ignition; $\mathrm{FeO} *=$ total iron as $\mathrm{FeO} ;(\mathrm{Ce} / \mathrm{Y})_{\mathrm{N}}=$ Chondrite-normalized $\mathrm{Ce} / \mathrm{Y}$ ratio; $\mathrm{ClPW}$ Norms determined assuming an $\mathrm{Fe} 2 \mathrm{O}_{3} / \mathrm{FeO}$ ratio of 0.15 . 
Table 7. Neutron activation analyses of selected basalts, Site 483 .

\begin{tabular}{|c|c|c|c|c|}
\hline $\begin{array}{c}\text { Sample } \\
\text { (interval in } \mathrm{cm} \text { ) }\end{array}$ & $\begin{array}{c}483-15-2 \\
1-6\end{array}$ & $\begin{array}{c}483-24-1 \\
96-100\end{array}$ & $\begin{array}{c}483 \mathrm{~B}-4-5, \\
100-102\end{array}$ & $\begin{array}{c}483 \mathrm{~B}-21-2, \\
31-33\end{array}$ \\
\hline Unit & 2 & $7 \mathrm{a}$ & 2 & $7 \mathrm{~b}$ \\
\hline \multicolumn{5}{|c|}{ Trace Elements (ppm) } \\
\hline $\mathrm{La}$ & 1.9 & 4.7 & 1.9 & 3.3 \\
\hline $\mathrm{Ce}$ & 8.7 & 18.1 & 7.9 & 12.5 \\
\hline $\mathrm{Nd}$ & 8.1 & 18.1 & 7.2 & 12.7 \\
\hline $\mathrm{Sm}$ & 2.85 & 5.99 & 2.46 & n.a. \\
\hline $\mathrm{Eu}$ & 1.30 & 2.19 & 1.16 & 1.72 \\
\hline Gd & 4.03 & 9.00 & n.a. & 6.09 \\
\hline $\mathrm{Tb}$ & 0.75 & 1.53 & 0.70 & 1.12 \\
\hline $\mathrm{Tm}$ & 0.50 & 0.96 & 0.46 & 0.70 \\
\hline $\mathrm{Yb}$ & 3.14 & 6.09 & 2.82 & 4.48 \\
\hline $\mathrm{Lu}$ & 0.50 & 0.97 & 0.48 & 0.73 \\
\hline Th & 0.12 & 0.40 & 0.12 & n.a. \\
\hline $\mathrm{Ta}$ & 0.10 & 0.29 & 0.11 & 0.20 \\
\hline $\mathrm{Hf}$ & 2.22 & 4.76 & 1.95 & 3.28 \\
\hline \multicolumn{5}{|l|}{ Selected Ratios } \\
\hline $\mathrm{LaN}_{\mathrm{N}} / \mathrm{Yb}_{\mathrm{N}}$ & 0.44 & 0.51 & 0.45 & 0.49 \\
\hline $\mathrm{La} / \mathrm{Ta}$ & 19 & 16 & 17 & 17 \\
\hline $\mathrm{Th} / \mathrm{Hf}$ & 0.05 & 0.08 & 0.06 & - \\
\hline
\end{tabular}

Note: n.a. $=$ not analyzed

play low contents of the more-HYG elements and low more-HYG/HYG element ratios. In addition, the basalts from Site 483 show considerable variation, both in absolute trace element abundances (e.g., $\mathrm{Zr}$ varies from 46 to 144 ppm) and in their $\mathrm{FeO}^{*} / \mathrm{MgO}$ ratios (Fig. 11). However, the basalts produce a smooth trend when the concentration of an HYG-element (e.g., $\mathrm{Zr}$ or $\mathrm{Ti}$ ) is plotted against the $\mathrm{FeO}^{*} / \mathrm{MgO}$ ratio, unlike the strongly bimodal distribution shown by the Site 482 basalts (compare Figs. 4 and 11).

Lithologic units from similar stratigraphic levels in the two holes show close chemical correspondence (Fig. 11), corroborating shipboard petrographic and chemical studies which conclude that the units probably represent laterally continuous flows or basalt types. These interhole similarities are also demonstrated in Figure 10. It is therefore not unreasonable to consider Holes 483 and 483B together when discussing the chemical variations at Site 483.

From Figure 11 it is evident that the aphyric units from both holes tend to consist of the least evolved basalts, at least in terms of $\mathrm{FeO}^{*} / \mathrm{MgO}$ ratios and HYGelement content. With the exception of Units 483-4 and 483B-4, however, the $\mathrm{Ni}$ and $\mathrm{Cr}$ contents are not particularly high in the aphyric units, and aphyric units 483B-6a and 483B-6b represent more evolved basalts. Nevertheless, there does appear to be a change in phenocryst abundance and composition between Units 4 and 5 in both holes.

The Ni contents tend to decrease with increasing $\mathrm{FeO}^{*} / \mathrm{MgO}$ ratio (Fig. 11), indicating the removal of olivine and/or clinopyroxene from the melt. As mentioned above, Units 483-4 and 483B-4 have moderately high $\mathrm{Ni}$ contents $(\sim 110 \mathrm{ppm})$, but these abundances are still much lower than in many "primitive" mid-ocean ridge basalt (MORB) ( $\sim 200$ ppm: Kay et al., 1970). Unit 483B-9 also has a moderately high Ni content, although some of this Ni may be due to the presence of cumulus olivine and clinopyroxene. The remaining samples contain $<80 \mathrm{ppm} \mathrm{Ni}$, suggesting that significant olivine fractionation occurred prior to eruption.

With the exceptions of Units 483-4, 483B-3, and 483B-4, all of the analyzed basalts from Site 483 have between 100 and $130 \mathrm{ppm} \mathrm{Sr}$, and the $\mathrm{Sr}$ levels tend to remain constant with increasing $\mathrm{Zr}$ content (Figs. 8 and 11). This suggests that plagioclase fractionation played an important role during the formation of these basalts. Also, the higher Sr contents of Units 483-4 and 483B-4 are consistent with their more primitive chemistry.

The smooth trend on the $\mathrm{Sr}$ versus $\mathrm{Zr}$ diagram (Fig. 8 ), together with the low abundances of $\mathrm{K}_{2} \mathrm{O}, \mathrm{Rb}$, and $\mathrm{Ba}$ (Tables 5 and 6, and Fig. 5), corroborates petrographic evidence that the basalts recovered at Site 483 are relatively fresh, having undergone only minor alteration by seawater. In addition, the low abundances of the LIL-elements demonstrates the depleted N-type MORB chemistry of these samples. Smooth trends are also produced when two "immobile" HYG elements are plotted against one another. For example, plots of Y versus $\mathrm{Zr}$ and $\mathrm{TiO}_{2}$ versus $\mathrm{Zr}$ (Figs. 6 and 7) show straight-line relationships with intercepts on the $\mathrm{Y}$ and $\mathrm{Ti}$ axes, respectively. These trends are essentially identical to those observed for the Site 482 samples. Again, the $\mathrm{Zr} / \mathrm{Ti}$ and $\mathrm{Zr} / \mathrm{Y}$ ratios increase with increasing $\mathrm{Zr}$ content, but they remain significantly lower than the ratios observed for the Site 474 and Guaymas Basin basalts.

Chondrite-normalized REE patterns for selected basalts from Site 483 are plotted in Figure 12. The shapes of the patterns are identical to those observed for the Site 482 basalts, and the $\mathrm{La}_{\mathrm{N}} / \mathrm{Sm}_{\mathrm{N}}$ and $\mathrm{La}_{\mathrm{N}} / \mathrm{Yb}_{\mathrm{N}}$ ratios are again significantly less than 1 (Table 7). The absolute REE abundances vary in sympathy with the $\mathrm{FeO}^{*}$ / $\mathrm{MgO}$ ratios and other HYG-element contents (e.g., $\mathrm{Zr}$ ) and the $\mathrm{La} / \mathrm{Yb}$ ratios increase with increasing $\mathrm{La}$ content (Fig. 13). The samples from Units 483-2 and 483B-2 have significant positive Eu anomalies, although both units are aphyric, which rules out cumulus plagioclase as the cause of the Eu enhancement. It is interesting to note that the two most primitive basalts from the uppermost part of the sequence at Site 482 also have positive Eu anomalies.

The Site 483 basalts have high La/Ta ratios (17-19) and low $\mathrm{Th} / \mathrm{Hf}$ ratios $(0.05-0.08)$ (Table 7$)$, which are essentially identical to those observed for the Site 482 basalts (Figs. 14 and 15) and for N-type basalts from the North Atlantic Ocean (e.g., Leg 45: Bougault et al., 1978).

\section{Site 483: Discussion}

The basement structure revealed at Site 483-massive flows which are laterally continuous between holes-is very similar to that found at Site 482 . Indeed, the correspondence between holes is probably even closer than that at Site 482 (Fig. 10). One immediate conclusion which can be drawn from these observations is that this 


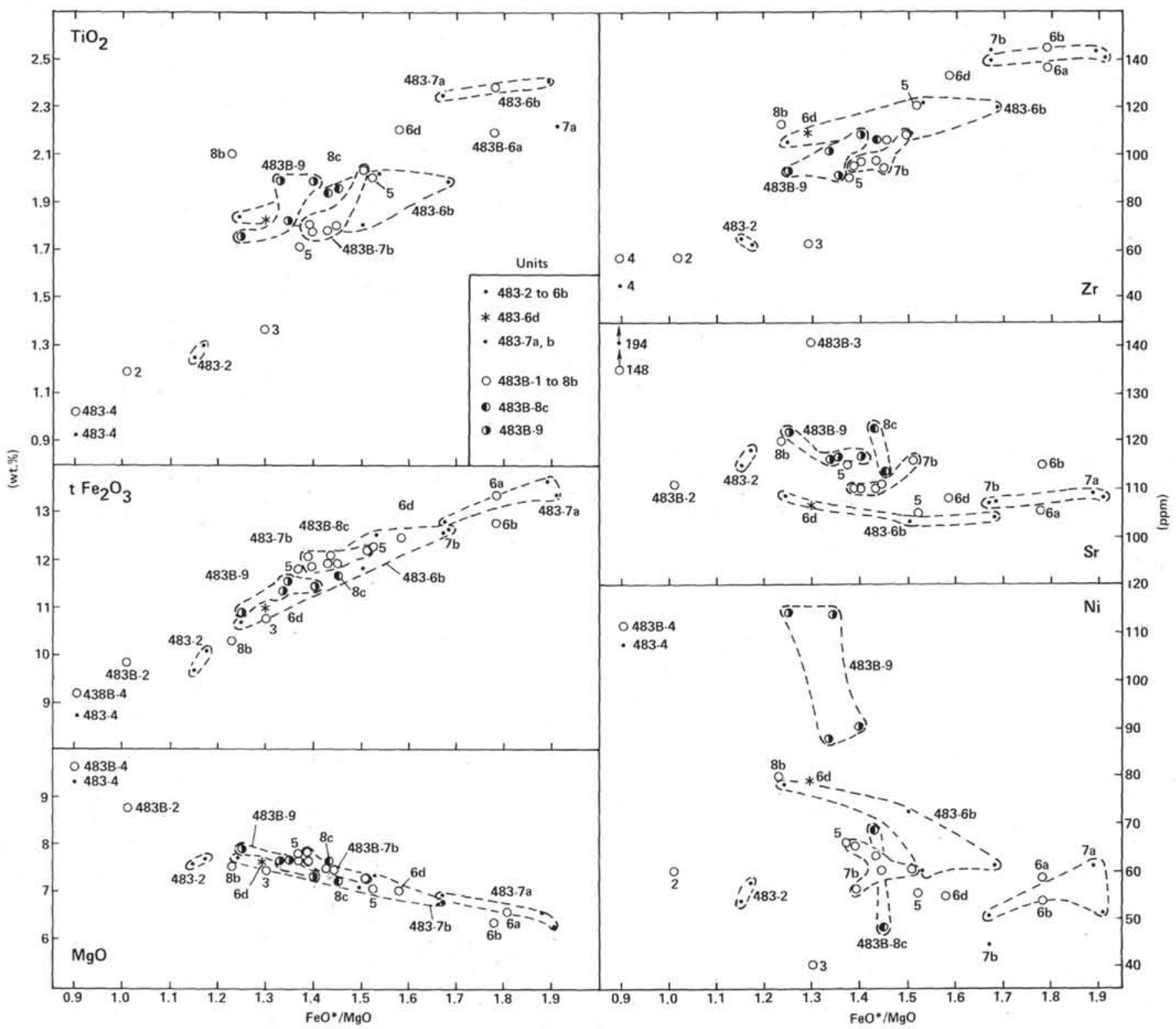

Figure 11. Selected major element oxides and trace elements vs. $\mathrm{FeO}^{*} / \mathrm{MgO}$ ratio, Site 483 . $\left(\mathrm{tFe}_{2} \mathrm{O}_{3}=\right.$ total iron as $\mathrm{Fe}_{2} \mathrm{O}_{3} ; \mathrm{FeO}^{*}=$ total iron as $\mathrm{FeO}$. Numbering of chemical units as in Fig. 10.)

type of crustal structure is not restricted to one site and may underlie large portions of the region.

Chemically, the basalts from Site 483 closely resemble those recovered at Site 482 . This is particularly true of the more-HYG/more-HYG element ratios (Fig. 14), the more-HYG/HYG element ratios (Figs. 5, 13, 15) and even the HYG/HYG element ratios (Figs. 6 and 7). However, there are several differences between the basalts from the two sites. First, the grouping of the Site 482 basalts into two distinct chemical types is not obviously seen at Site 483 ; rather, there is a systematic increase in HYG-element abundances with increasing $\mathrm{FeO}^{*} / \mathrm{MgO}$ ratio (Fig. 11). Secondly, the total iron content tends to be higher in the Site 483 basalts (up to $13.7 \% \mathrm{Fe}_{2} \mathrm{O}_{3}$, which is approaching the composition of ferrobasalt) and the HYG element contents are also higher. Thirdly, in both Hole 483 and Hole 483B there is a clear break between the aphyric, more primitive basalts of Units 1 through 4 and the more evolved basalts of Units 5 through 9. There is not, however, a systematic increase in the HYG-element content with depth below Unit 4; evolved and moderately evolved basalts are intercalated.

Intraunit chemical variations in Units 483-6, 483B-8c, and 483B-9 can be readily explained by closed-system fractional crystallization involving olivine, plagioclase, and perhaps clinopyroxene. The same may be true of Units 2, 3, and 4 in both holes, since HYG-element and $\mathrm{FeO}^{*} / \mathrm{MgO}$ ratio increases are accompanied by corresponding decreases in Ni content (Fig. 11), although the absence of phenocrysts in these units implies that fractionation occurred at moderately high pressures. Such a simple model cannot, however, be invoked to relate the other units at Site 483 because of the apparent discrep- 


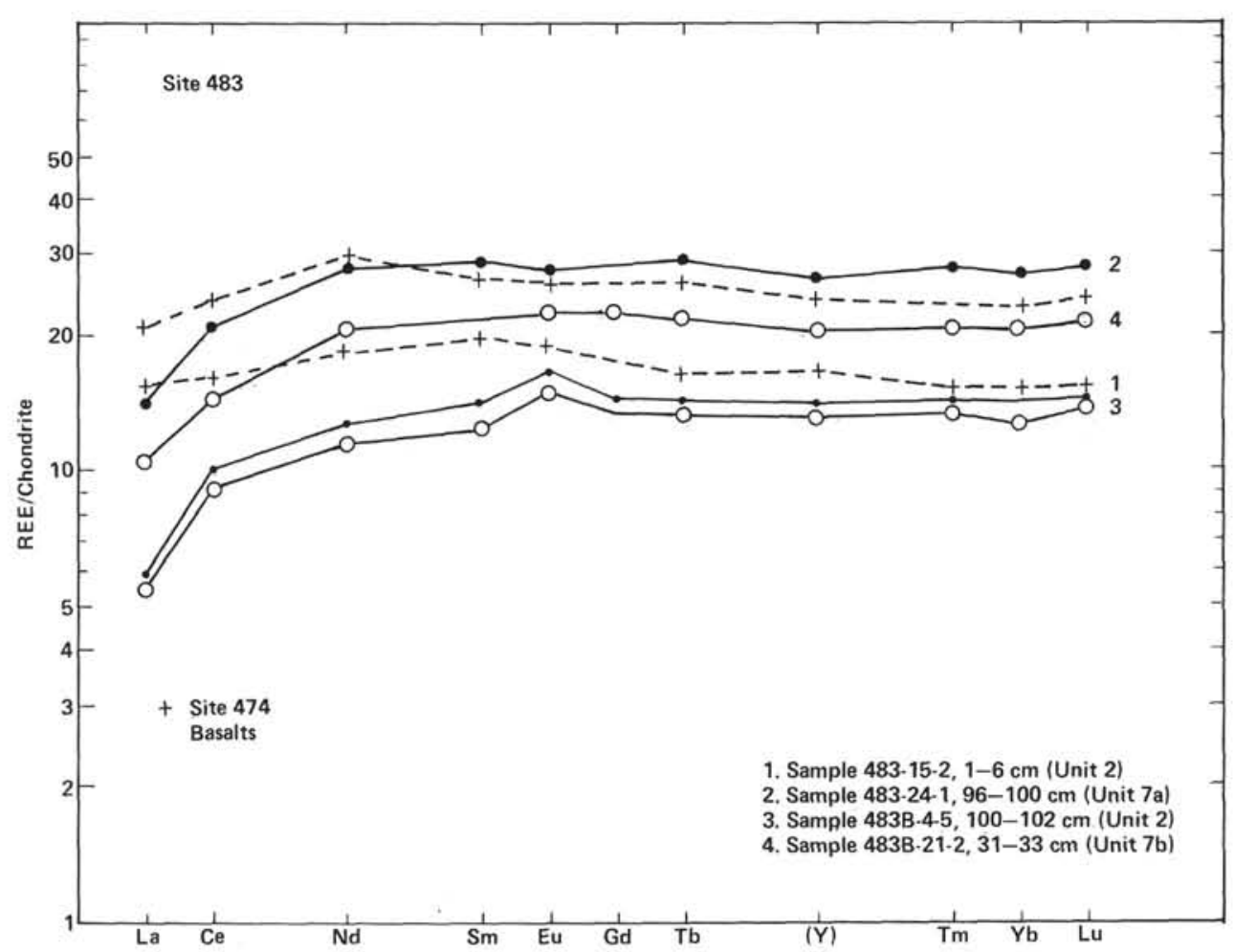

Figure 12. Chondrite-normalized rare earth element (REE) patterns for selected basalts from Site 483. (Y values were determined by XRF, the remainder by INAA. REE patterns for basement samples from Site 474 are from Saunders et al: [in press].)

ancies between $\mathrm{FeO} / \mathrm{MgO}$ ratio and $\mathrm{HYG}$-element contents (cf. Site 482). Clearly, the basalts could have been derived from a common parental melt, but they probably represent magma batches derived from a single open magma chamber, or several magma chambers as suggested by the intercalation of moderately evolved and evolved basalts.

The constancy of the more-HYG/HYG and moreHYG/more-HYG element ratios between Sites 482 and 483 implies that the mantle sources from which the basalts were derived had virtually identical chemistries, at least as far as these ratios are concerned, and that the processes of magma generation in the mantle at both sites were very similar (cf. discussions in Bougault et al., 1980).

\section{SITE 485}

Site 485 was located at $22^{\circ} 44.9^{\prime} \mathrm{N}, 107^{\circ} 54.2^{\prime} \mathrm{W}$ in 2981 meters of water approximately $12 \mathrm{~km}$ to the east of Site 482 and $25 \mathrm{~km}$ from the East Pacific Rise (Fig. 1). Hole $485 \mathrm{~A}$ reached acoustic basement at 153.5 meters sub-bottom and drilled through 178 meters of interlayered massive basalts and sediments. The basement at this site has an estimated age of 0.9 m.y.

\section{Hole 485A}

Eight units of massive basalt have been recognized by the shipboard party (Fig. 16). Unlike the other basalts recovered during Leg 65, the phenocryst content is always low (less than $5 \%$ ), but the assemblages are variable, including olivine and spinel, plagioclase + clinopy- roxene + olivine, and plagioclase + olivine. Unit 1, which is 7.2 meters thick, consists of four thin, massive cooling units and one slightly thicker cooling unit. The phenocryst content and assemblages of Unit 1 vary considerably; the single sample taken for analysis during the present study was from Cooling Unit 3 (plagioclase $>$ clinopyroxene $>$ olivine).

Unit 2 ( $4.4 \mathrm{~m}$ thick) consists of one or possibly two cooling units of massive basalt which are sparsely plagioclase-phyric or aphyric. No samples were taken for analysis from either this unit or the underlying Unit 3. The latter consists of a plagioclase-phyric basalt, possibly pillowed, of which very little was recovered.

Unit 4 (13.9 m thick) is a thick, massive, sparsely olivine-plagioclase-phyric basalt displaying a coarsegrained texture in the center of the unit. Two samples were taken for analysis. Unit 5 ( $27.1 \mathrm{~m}$ thick) is a massive coarse-grained basalt which is very sparsely plagioclase-olivine-phyric. The unit has been tentatively interpreted by the shipboard party as a single cooling unit, although it may consist of several flow or intrusive batches that were emplaced sufficiently rapidly to form a complex cooling unit. It is not clear whether this unit is intrusive or extrusive in origin. Samples were taken from the upper and lower portions of the unit.

Unit $6(10.0 \mathrm{~m}$ thick) also consists of a massive basalt which is very sparsely olivine and plagioclase-phyric. Two samples were taken for analysis. A thin unit of massive basalt was recorded at 299 meters sub-bottom (Unit 7). Unit 8, in which the drilling was finally terminated, consists of sparsely plagioclase-phyric massive 


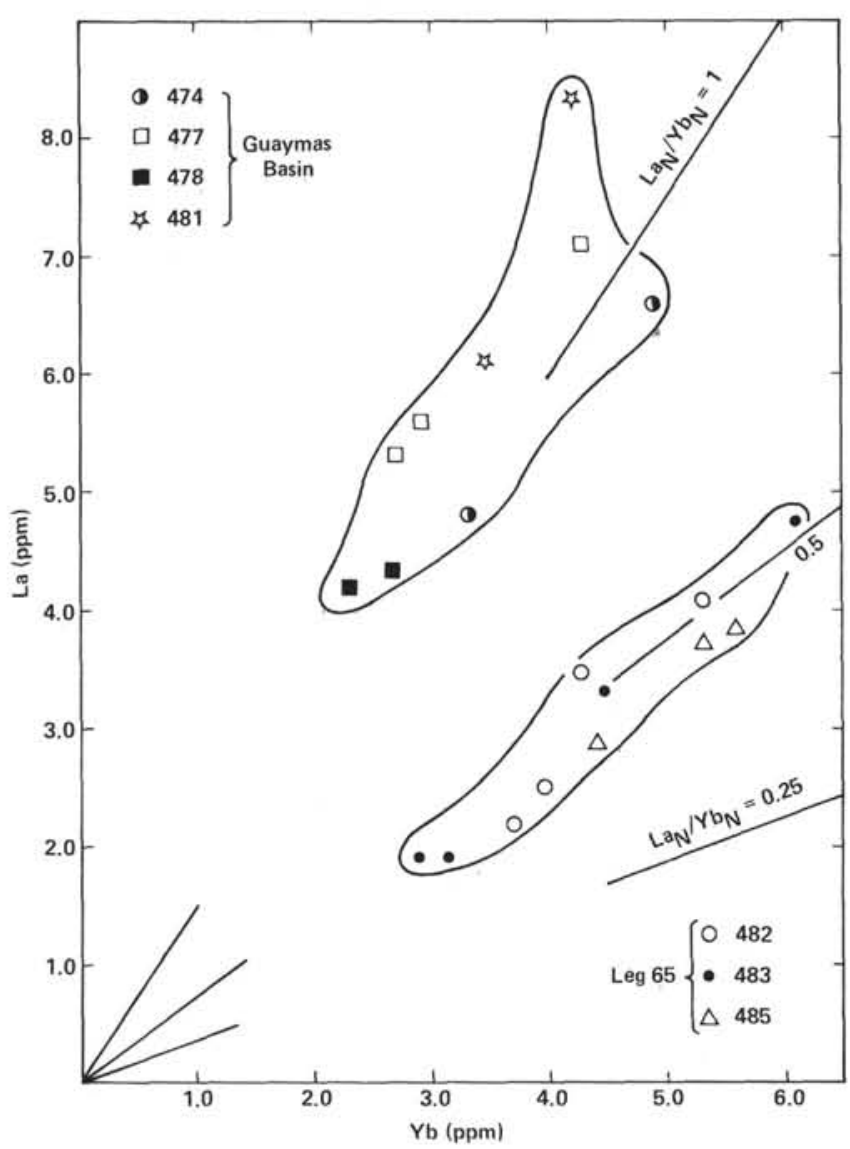

Figure 13. La vs. Yb for basalts recovered on Legs 64 and 65. (Leg 64 data from Saunders et al. [in press].)

basalt; the nature of the upper contact suggests that the unit may be intrusive in origin.

In general, the basalts from Hole $485 \mathrm{~A}$ are more extensively altered than those from Sites 482 and 483, with no fresh olivine being observed in any of the thin sections. The low temperature assemblage consists of smectite, carbonate, sulfides, and, occasionally, zeolites and silica deposited in veins and vesicles. Higher-temperature secondary minerals were seen in Cores 17 and 24 through 33 , in which chlorite was observed replacing smectite. Details of the alteration of these samples have been presented elsewhere (Morrison and Thompson, this volume).

Analyses of basalts recovered at Site 485 are given in Tables 8 and 9 , although insufficient samples were taken to make the present study comprehensive. An inherent analytical advantage provided by the basalts from Hole $485 \mathrm{~A}$ is their very low phenocryst content, which implies that the whole-rock analyses represent liquid compositions. As in the previous holes, the basalts are all subalkaline tholeiites, falling inside the Di-Ol-Hy field of the basalt tetrahedron (Fig. 3). However, although the basalts from Hole 485A show a wide compositional range (e.g., $\mathrm{Zr}$ varies between $104 \mathrm{ppm}$ in Unit 6 to at least $138 \mathrm{ppm}$ in Unit 5), no basalts with the primitive, low HYG element chemistry typical of Chemical Type I from Site 482 (or Units 2, 3, and 4 from Site 483) were analyzed during this study. This may of course be a

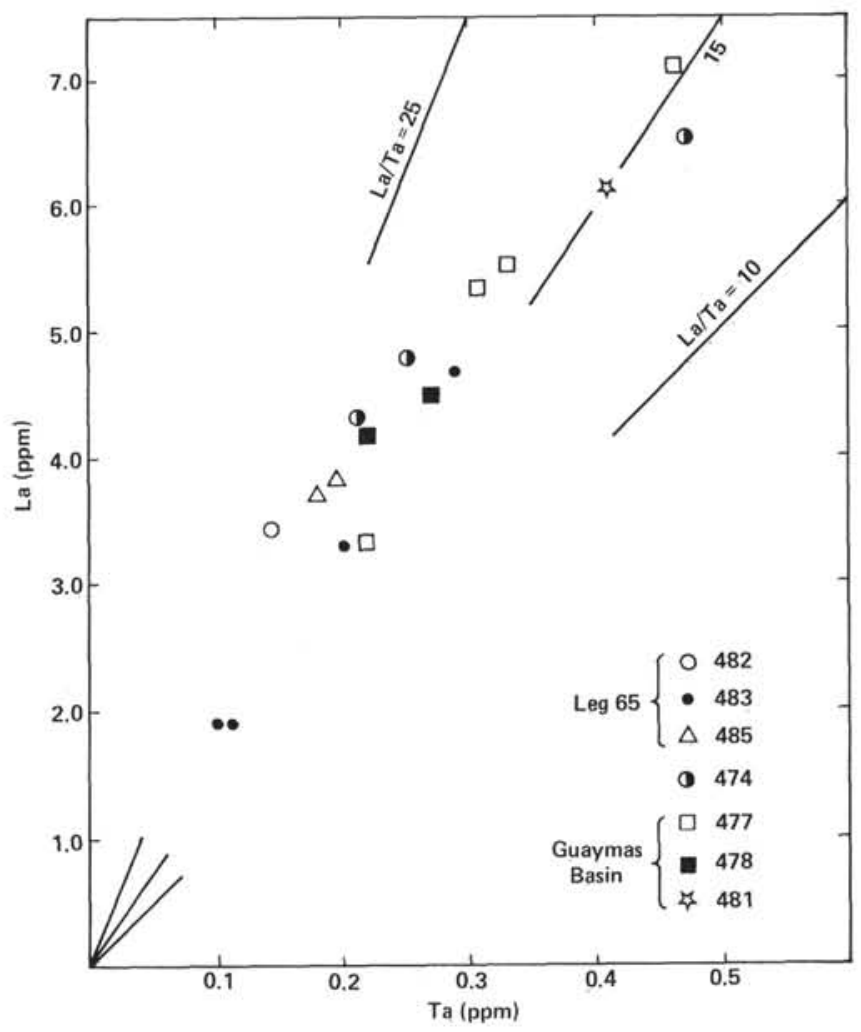

Figure 14. La vs. Ta for basalts recovered on Legs 64 and 65. (Leg 64 data from Saunders et al. [in press].)

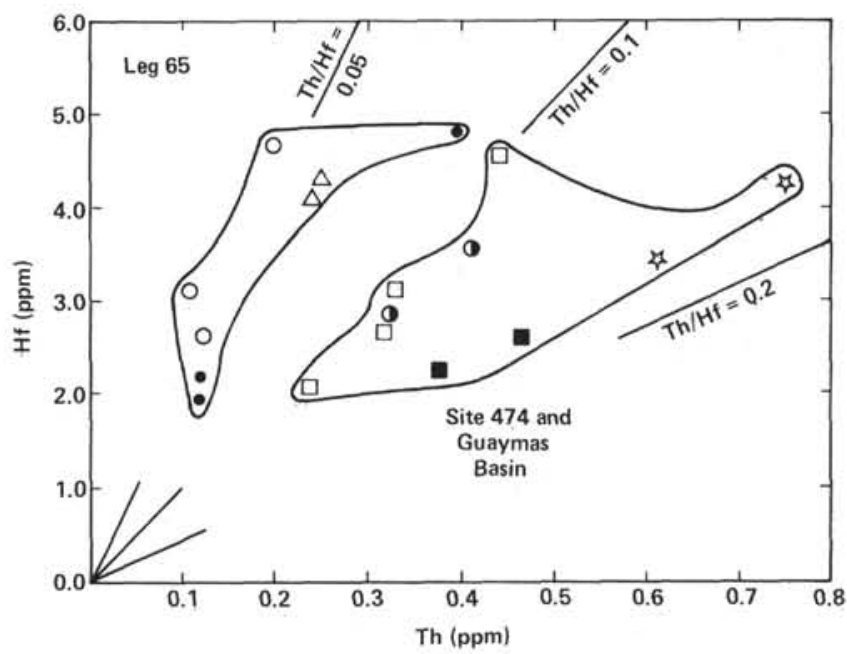

Figure 15. Hf vs. Th for basalts recovered on Legs 64 and 65. (Leg 64 data from Saunders et al. [in press]. Symbols as in Figs. 13 and 14.)

function of the low sampling density, but apart from Sample 485A-11-3, 82-83 cm, none of the samples from Hole $485 \mathrm{~A}$ which was analyzed on shipboard contains less $\mathrm{Zr}$ than those analyzed here. It would appear therefore that most of the analyzed basalts from Hole 485A are similar to the more evolved basalts from Sites 482 and 483 . This is demonstrated not only by the HYG element contents but also by the high $\mathrm{FeO} * / \mathrm{MgO}$ ratios and the total iron contents (e.g., Fig. 17). 


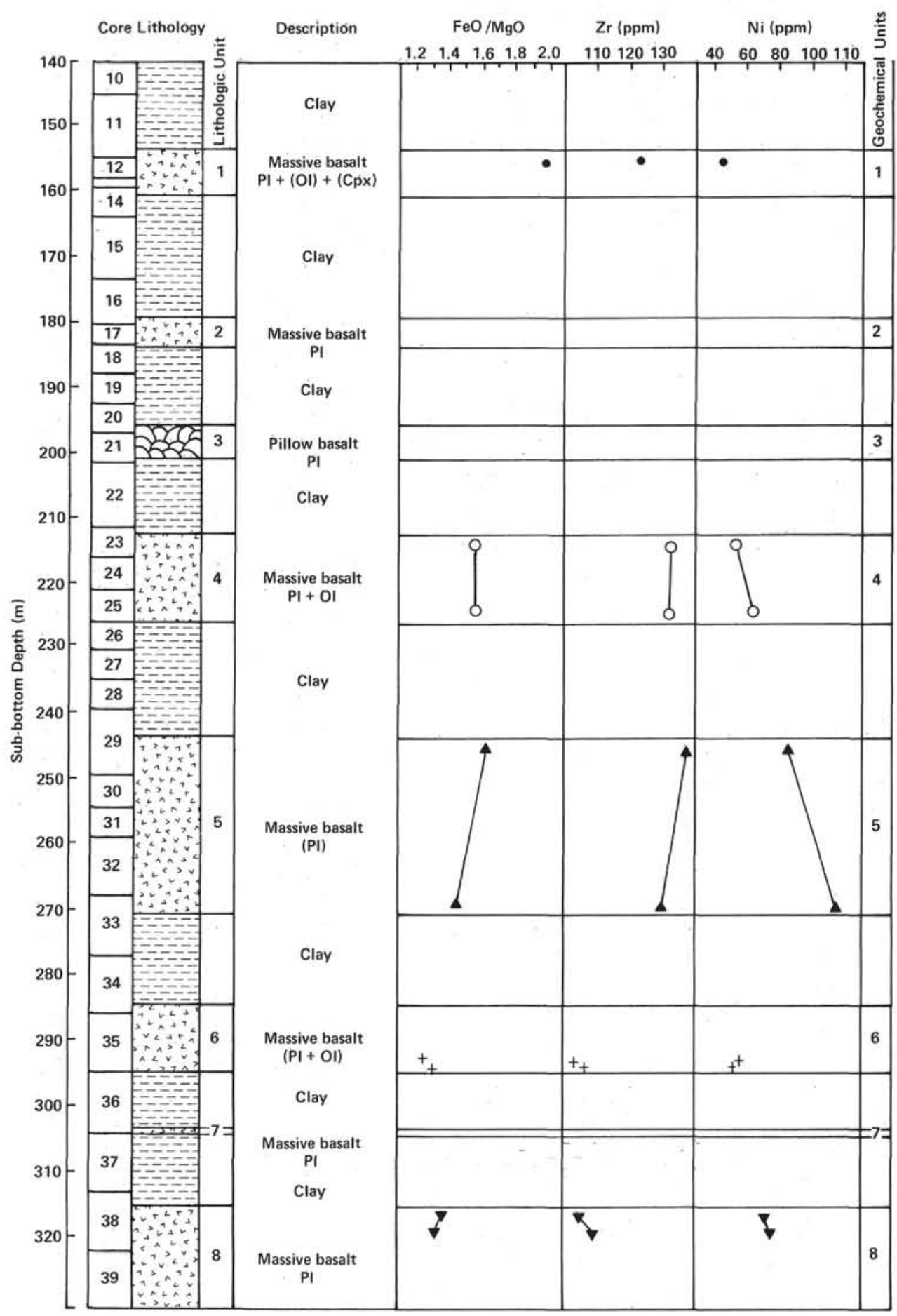

Figure 16. Lithology, mineralogy, and selected geochemical parameters vs. depth in Hole $485 \mathrm{~A}$. (FeO* represents total iron.) (See symbols Fig. 17).

As in the case of the basalts from Site 483, the HYG element contents increase with increasing $\mathrm{FeO}^{*} / \mathrm{MgO}$ ratio. However, there are considerable intraunit variations in the more massive units (e.g., Unit 485A-5; Figs. 16 and 17$): \mathrm{Zr}$ increases and $\mathrm{Ni}$ decreases, for example, with increases in the $\mathrm{FeO} * \mathrm{MgO}$ ratio. Since Unit 485A5 is essentially aphyric, it is unlikely that the observed intraunit variations result from crystal settling. It is more probable that they are a function of the changing com- position of successive magma batches. This is supported to some extent by textural observations (previously mentioned) which suggest that Unit 5 consists of several intrusive subunits.

A further complication is introduced by considering the interunit variations in Hole $485 \mathrm{~A}$. Although $\mathrm{Zr}$ increases with increasing $\mathrm{FeO} * / \mathrm{MgO}, \mathrm{Ni}$ (which normally decreases both with increasing $\mathrm{Zr}$ and with increasing $\mathrm{FeO}^{*} / \mathrm{MgO}$ ) exhibits an overall trend of enrichment 


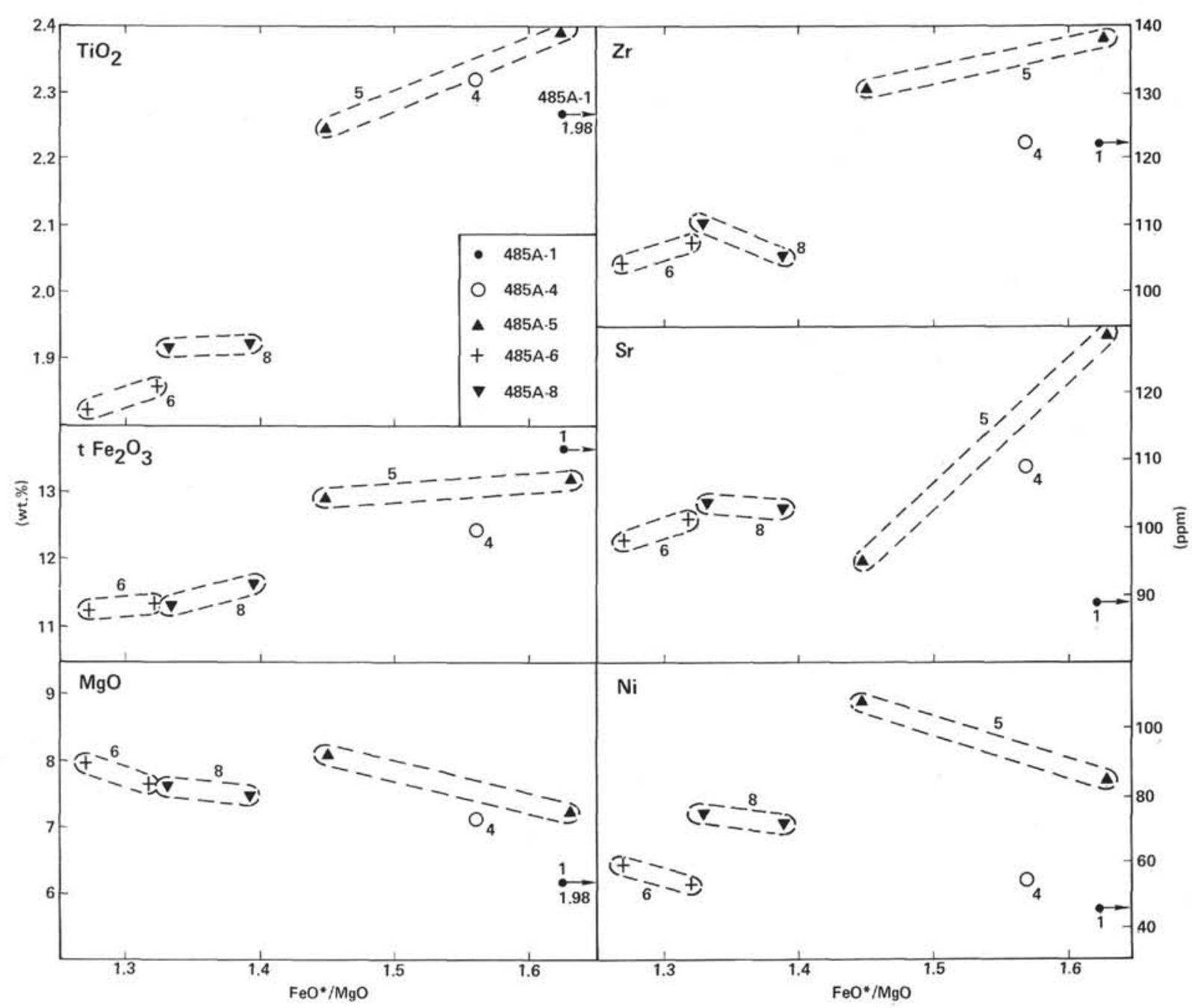

Figure 17. Selected major element oxides and trace elements vs. $\mathrm{FeO} * / \mathrm{MgO}$ ratio, Site 485 . $\left(\mathrm{tFe}_{2} \mathrm{O}_{3}=\right.$ total iron as $\mathrm{Fe}_{2} \mathrm{O}_{3}$; $\mathrm{FeO}^{*}=$ total iron as FeO. Numbering of chemical units and symbols as in Fig. 16.)

when Units $485 \mathrm{~A}-5,6$, and 8 are considered as a group (Fig. 17). This implies that these units are not related by simple closed-system fractional crystallization.

Both the content of the more-HYG elements and the more-HYG/HYG element ratios are low and generally indistinguishable from those seen in the basalts from Sites 482 and 483 (Tables 8 and 9). Most of the basalts from Hole 485A display low contents of the LIL-elements $\mathrm{K}, \mathrm{Rb}$, and $\mathrm{Sr}$, suggesting that the effects of seawater interaction have been slight, even though the petrographic evidence indicates that the basalts from Hole $485 \mathrm{~A}$ are more altered than those from Sites 482 and 483 . One sample from Unit $485 \mathrm{~A}-5$, however, has a higher $\mathrm{Sr}$ content $(129 \mathrm{ppm})$ than normal, which may be due in part to seawater (or sediment porewater) interaction, and two samples are enriched in $\mathrm{K}_{2} \mathrm{O}$ and $\mathrm{Rb}$.

Chondrite-normalized REE patterns for the basalts from Hole 485A are shown in Figure 18. The patterns are remarkably parallel, all showing strong light-REE depletion $\left(\mathrm{La}_{\mathrm{N}} / \mathrm{Yb}_{\mathrm{N}} \sim 0.4\right)$ similar to that at Sites 482 (Fig. 9) and 483 (Fig. 12). These samples are unlike the more primitive basalts from the other sites, however, in that no europium anomalies are observed.
Abundance ratios involving the more immobile elements $\mathrm{Ti}, \mathrm{Zr}, \mathrm{Y}, \mathrm{La}, \mathrm{Ta}, \mathrm{Th}$, and $\mathrm{Hf}$ are consistent and closely resemble those found in the basalts from Sites 482 and 483 . The $\mathrm{Zr} / \mathrm{Y}$ (Fig. 5), $\mathrm{Zr} / \mathrm{Ti}$ (Fig. 6), and $\mathrm{La} / \mathrm{Yb}$ (Fig. 13) ratios increase with increasing fractionation, but the $\mathrm{La} / \mathrm{Ta}$ ratios $(\sim 20$, Fig. 14$)$ and $\mathrm{Th} / \mathrm{Hf}$ ratios ( $\sim 0.06$, Fig. 15$)$ remain constant.

\section{Site 485: Discussion}

The recovery of basement samples at Site 485 has reinforced observations made at Sites 482 and 483 regarding the structure of the upper portion of the ocean crust, the chemistry of the basalts, and the implied composition of the mantle source at the mouth of the Gulf. It is probable that at least one lithologic unit recovered at Site 485 (485A-5) represents an intrusive body, but the majority of the units appear to be extrusive in nature and consist of massive basalts.

Compositionally, the basalts closely resemble the more evolved samples recovered from Sites 482 and 483 , and there is a tendency towards ferrobasaltic compositions. Although the HYG-element content increases with increases in the $\mathrm{FeO}^{*} / \mathrm{MgO}$ ratio (Fig. 17), corresponding 
Table 8. X-ray fluorescence analyses of basalts, Hole 485A.

\begin{tabular}{|c|c|c|c|c|c|c|c|c|c|}
\hline $\begin{array}{c}\text { Sample } \\
\text { (level in } \mathrm{cm} \text { ) }\end{array}$ & $\begin{array}{l}12-1, \\
122\end{array}$ & $\begin{array}{c}23-2, \\
30\end{array}$ & $\begin{array}{c}25-1 \\
117\end{array}$ & $\begin{array}{c}29-1 \\
30\end{array}$ & $\begin{array}{c}33-2 \\
68\end{array}$ & $\begin{array}{l}35-5 \\
70\end{array}$ & $\begin{array}{c}35-6, \\
2\end{array}$ & $\begin{array}{l}38-2 \\
85\end{array}$ & $\begin{array}{c}38-5, \\
9\end{array}$ \\
\hline Unit & 1 & 4 & 4 & 5 & 5 & 6 & 6 & 8 & 8 \\
\hline \multicolumn{10}{|c|}{ Major Elements (wt.\%) } \\
\hline $\mathrm{SiO}_{2}$ & 48.82 & 48.90 & 49.34 & 48.98 & 48.12 & 49.49 & 49.29 & 48.90 & 49.08 \\
\hline $\mathrm{TiO}_{2}$ & 2.26 & 2.31 & 2.34 & 2.38 & 2.24 & 1.82 & 1.85 & 1.92 & 1.92 \\
\hline $\mathrm{Al}_{2} \mathrm{O}_{3}$ & 14.69 & 14.87 & 14.79 & 14.34 & 15.00 & 15.02 & 15.05 & 15.54 & 15.52 \\
\hline $\mathrm{tFe}_{2} \mathrm{O}_{3}$ & 13.64 & 12.41 & 12.60 & 13.12 & 12.93 & 11.23 & 11.26 & 11.58 & 11.27 \\
\hline $\mathrm{MnO}$ & 0.21 & 0.18 & 0.18 & 0.17 & 0.18 & 0.17 & 0.16 & 0.17 & 0.16 \\
\hline $\mathrm{MgO}$ & 6.2 & 7.1 & 7. 2 & 7.3 & 8.0 & 7.9 & 7.7 & 7.5 & 7.7 \\
\hline $\mathrm{CaO}$ & 11.92 & 11.23 & 11.09 & 11.10 & 10.72 & 11.54 & 11.47 & 11.35 & 11.51 \\
\hline $\mathrm{Na}_{2} \mathrm{O}$ & 2.64 & 2.69 & 2.57 & 2.34 & 2.41 & 2.53 & 2.66 & 2.54 & 2.67 \\
\hline $\mathrm{K}_{2} \mathrm{O}$ & 0.06 & 0.10 & 0.17 & 0.11 & 0.19 & 0.07 & 0.07 & 0.09 & 0.07 \\
\hline $\mathrm{P}_{2} \mathrm{O}_{5}$ & 0.16 & 0.26 & 0.19 & 0.25 & 0.23 & 0.20 & 0.19 & 0.18 & 0.21 \\
\hline LOI & - & - & 0.07 & 0.13 & - & +0.16 & - & 0.52 & - \\
\hline Total & 100.60 & 100.15 & 100.55 & 100.18 & 100.03 & 99.84 & 99.65 & 100.30 & 100.06 \\
\hline
\end{tabular}

Trace Elements (ppm)

$\begin{array}{lrrrrrrrrr}\mathrm{Ni} & 46 & 55 & 63 & 86 & 108 & 59 & 57 & 72 & 75 \\ \mathrm{Cr} & 157 & 217 & 165 & 226 & 194 & 223 & 216 & 182 & 189 \\ \mathrm{Zn} & 93 & 85 & 87 & 78 & 95 & 71 & 67 & 74 & 77 \\ \mathrm{Ga} & 21 & 23 & 19 & 23 & 20 & 25 & 26 & 24 & 20 \\ \mathrm{Rb} & <1 & 1 & 1.7 & 2 & 4 & 1 & <1 & 2 & <1 \\ \mathrm{Sr} & 89 & 109 & 102 & 129 & 95 & 98 & 101 & 103 & 104 \\ \mathrm{Y} & 48 & 47 & 46 & 46 & 45 & 40 & 41 & 41 & 42 \\ \mathrm{Zr} & 122 & 135 & 131 & 138 & 130 & 104 & 107 & 106 & 110 \\ \mathrm{Nb} & 3 & 2 & 2 & 2 & 3 & 2 & 2 & 2 & 2 \\ \mathrm{Ba} & 40 & 32 & 25 & 29 & 26 & 28 & 29 & 21 & 23 \\ \mathrm{La} & 7 & 6 & 6 & 7 & 6 & 5 & 6 & 5 & 4 \\ \mathrm{Ce} & 11 & 17 & 16 & 15 & 16 & 12 & 13 & 12 & 12 \\ \mathrm{Nd} & 13 & 13 & 14 & 13 & 14 & 11 & 13 & 11 & 13\end{array}$

\begin{tabular}{|c|c|c|c|c|c|c|c|c|c|}
\hline \multicolumn{10}{|l|}{ Selected Ratios } \\
\hline $\mathrm{FeO} * / \mathrm{MgO}$ & 1.98 & 1.57 & 1.57 & 1.63 & 1.45 & 1.27 & 1.32 & 1.39 & 1.33 \\
\hline $\mathrm{Zr} / \mathrm{Nb}$ & 41 & 68 & 66 & 69 & 65 & 52 & 54 & 53 & 55 \\
\hline $\mathrm{Ti} / \mathrm{Zr}$ & 111 & 103 & 107 & 103 & 103 & 105 & 104 & 109 & 105 \\
\hline $\mathrm{Ba} / \mathrm{Zr}$ & 0.33 & 0.24 & 0.19 & 0.21 & 0.20 & 0.27 & 0.27 & 0.20 & 0.21 \\
\hline $\mathrm{K} / \mathrm{Rb}$ & $>500$ & $>800$ & 833 & 458 & 396 & 583 & $>583$ & 375 & $>580$ \\
\hline $\mathrm{Ba} / \mathrm{Sr}$ & 0.45 & 0.29 & 0.25 & 0.22 & 0.27 & 0.29 & 0.29 & 0.20 & 0.22 \\
\hline$(\mathrm{Ce} / \mathrm{Y})_{\mathrm{N}}$ & 0.5 & 0.8 & 0.8 & 0.7 & 0.8 & 0.6 & 0.7 & 0.6 & 0.6 \\
\hline \multicolumn{10}{|c|}{ CIPW Norms $(\%)$} \\
\hline Or & 0.4 & 0.6 & 1.0 & 0.7 & 1.1 & 0.4 & 0.4 & 0.5 & 0.4 \\
\hline $\mathrm{Ab}$ & 22.3 & 22.8 & 21.7 & 19.8 & 20.4 & 21.4 & 22.5 & 21.5 & 22.6 \\
\hline An & 28.1 & 28.2 & 28.3 & 28.3 & 29.6 & 29.4 & 28.9 & 30.7 & 30.2 \\
\hline $\mathrm{Di}$ & 24.8 & 21.2 & 20.9 & 20.6 & 18.1 & 21.6 & 21.8 & 19.9 & 20.9 \\
\hline $\mathrm{Hy}$ & 12.5 & 14.9 & 17.9 & 22.2 & 15.7 & 16.4 & 14.2 & 15.1 & 12.7 \\
\hline ol & 4.3 & 4.2 & 2.5 & 0.0 & 7.0 & 3.9 & 4.9 & 4.9 & 6.3 \\
\hline $\mathrm{Mt}$ & 2.3 & 2.1 & 2.2 & 2.3 & 2.2 & 1.9 & 1.9 & 2.0 & 1.9 \\
\hline Il & 4.3 & 4.4 & 4.4 & 4.5 & 4.3 & 3.5 & 3.5 & 3.6 & 3.6 \\
\hline Ap & 0.4 & 0.6 & 0.4 & 0.6 & 0.5 & 0.5 & 0.4 & 0.4 & 0.5 \\
\hline
\end{tabular}

Note: $\mathrm{tFe}_{2} \mathrm{O}_{3}=$ total iron as $\mathrm{Fe}_{2} \mathrm{O}_{3} ; \mathrm{LOI}=$ loss on ignition; $\mathrm{FeO} \bullet / \mathrm{MgO}=$ total iron as $\mathrm{FeO} ;(\mathrm{Ce} / \mathrm{Y})_{\mathrm{N}}=\mathrm{Chon}$ drite-normalized $\mathrm{Ce} / \mathrm{Y}$ ratio; CIPW Norms calculated assuming an $\mathrm{Fe}_{2} \mathrm{O}_{3} / \mathrm{FeO}$ ratio of 0.15 .

decreases in Ni content are not observed in the Site 485 basalts, suggesting that simple closed-system fractional crystallization is not the only mechanism responsible for the observed chemical variations. Rather, open system fractionation in an evolving magma chamber, or fractional crystallization in several discrete magma chambers, may be responsible.

The similarity of more-HYG/more-HYG, moreHYG/HYG, and HYG/HYG element ratios throughout the basalts from Sites 482,483 , and 485 implies that all of the basalts were derived from a compositionally similar, if not identical, source under similar conditions of partial melting (see Site 482 and 483 reports).

\section{LEG 65: DISCUSSION AND COMPARISONS WITH LEG 64}

From the foregoing discussions it is evident that although the basalts recovered during Leg 65 exhibit considerable intra- and intersite variations in terms of their major element chemistry, they show remarkable consistency in their HYG and more-HYG element ratios. The variations in major element chemistry and of course many of the variations in absolute abundances of the incompatible elements can be explained-at least on a qualitative basis-by fractional crystallization in open magma chambers.

The relative abundances of the incompatible elements, particularly the more-HYG elements, are less susceptible to the effects of fractional crystallization, even in open magma chambers (Pankhurst, 1977), or during partial melting processes, if the bulk distribution coefficients are sufficiently low $(<0.01)$ or equal. Thus the ratios of the more-HYG elements $\mathrm{Th}, \mathrm{Ta}, \mathrm{La}, \mathrm{Nb}$, and $\mathrm{Ba}$, and to a lesser extent the HYG elements, can be used to characterize the ratios of the basalt source within the mantle (but not necessarily the bulk mantle composition) (see for example Bougault et al., 1978, 1980; Tarney et al., 1980; Wood, Joron, Treuil, et al., 1979; 
Table 9. Neutron activation analyses of selected basalts, Site 485 .

\begin{tabular}{cccc}
\hline $\begin{array}{c}\text { Sample } \\
\text { (interval in cm) }\end{array}$ & $\begin{array}{c}485 \mathrm{~A}-25-1, \\
117-143\end{array}$ & $\begin{array}{c}485 \mathrm{~A}-29-1, \\
30-32\end{array}$ & $\begin{array}{c}485 \mathrm{~A}-35-5, \\
70-72\end{array}$ \\
Units & 4 & 5 & 6 \\
\hline Trace Elements (ppm) & & & \\
$\mathrm{La}$ & 3.7 & 3.8 & 2.9 \\
$\mathrm{Ce}$ & 14.4 & 15.0 & 10.6 \\
$\mathrm{Nd}$ & 15.0 & 15.8 & $\mathrm{n} . \mathrm{a}$. \\
$\mathrm{Sm}$ & 4.81 & $\mathrm{n} . \mathrm{a}$. & 3.61 \\
$\mathrm{Eu}$ & 1.91 & 1.94 & 1.60 \\
$\mathrm{Gd}$ & $\mathrm{n} . \mathrm{a}$. & 7.64 & 5.69 \\
$\mathrm{~Tb}$ & 1.34 & 1.39 & 1.16 \\
$\mathrm{Tm}$ & 0.80 & 0.90 & 0.77 \\
$\mathrm{Yb}$ & 5.30 & 5.62 & 4.44 \\
$\mathrm{Lu}$ & 0.86 & 0.92 & 0.74 \\
$\mathrm{Th}$ & 0.24 & 0.25 & $\mathrm{n} . \mathrm{a}$. \\
$\mathrm{Ta}$ & 0.18 & 0.19 & $\mathrm{n} . \mathrm{a}$. \\
$\mathrm{Hf}$ & 4.04 & 4.28 & 3.14 \\
$\mathrm{Selected} \mathrm{Ratios}$ & & & \\
LaN/YbN & & & \\
$\mathrm{La} / \mathrm{Ta}$ & 21 & 20 & - \\
$\mathrm{Th} / \mathrm{Hf}$ & 0.06 & 0.06 & - \\
\hline
\end{tabular}

Note: n.a. $=$ not analyzed.

Wood; Tarney, Varet, et al., 1979). As indicated in the Site 482 discussion, the HYG-elements have small but significant bulk distribution coefficients in the mineral assemblages extracted during the formation of ocean floor basalts (Arth and Hanson, 1975; McCallum and Charette, 1978; Pearce and Norry, 1979), so the ratios involving these elements (e.g., $\mathrm{La} / \mathrm{Yb}$ ) may be susceptible to the effects of partial melting and even fractional crystallization, particularly when the proportion of final melt is small. Thus the more-HYG/HYG element ratios $(\mathrm{La} / \mathrm{Yb})$ observed in the recovered basalts may not represent the ratio of the original source rock. This is particularly true of the HYG/HYG element ratios (e.g., $\mathrm{Zr} / \mathrm{Y}, \mathrm{Zr} / \mathrm{Ti}$ ), which in the case of the Leg 65 basalts, clearly increase with increasing fractionation.

Bearing these limitations in mind, various incompatible element ratios have been estimated for the sources of the Leg 64 and 65 basalts (Table 10). In addition, representative whole-rock analyses of the Leg 64 samples are presented for purposes of comparison in Table 11. The reader can visualize the ratios discussed by considering Figures $6(\mathrm{Zr} / \mathrm{Y}), 7(\mathrm{Zr} / \mathrm{Ti}), 13(\mathrm{La} / \mathrm{Yb}), 14(\mathrm{La} / \mathrm{Ta})$, and $15(\mathrm{Th} / \mathrm{Hf})$. From these ratios, it is possible to compare the source of the basalts recovered adjacent to the EPR (Sites 482, 485) with that of the basalts recovered near the continental margin (Site 474), and from the Guaymas Basin (Sites 477, 478, and 481). For convenience, the comparisons will be made along two transects, one across the mouth of the Gulf and one along the Gulf.

\section{Gulf Mouth Transect}

Drilling during Legs 64 and 65 has provided material from what is in effect a unique crustal transect extending from very close to a fast-spreading center to within a

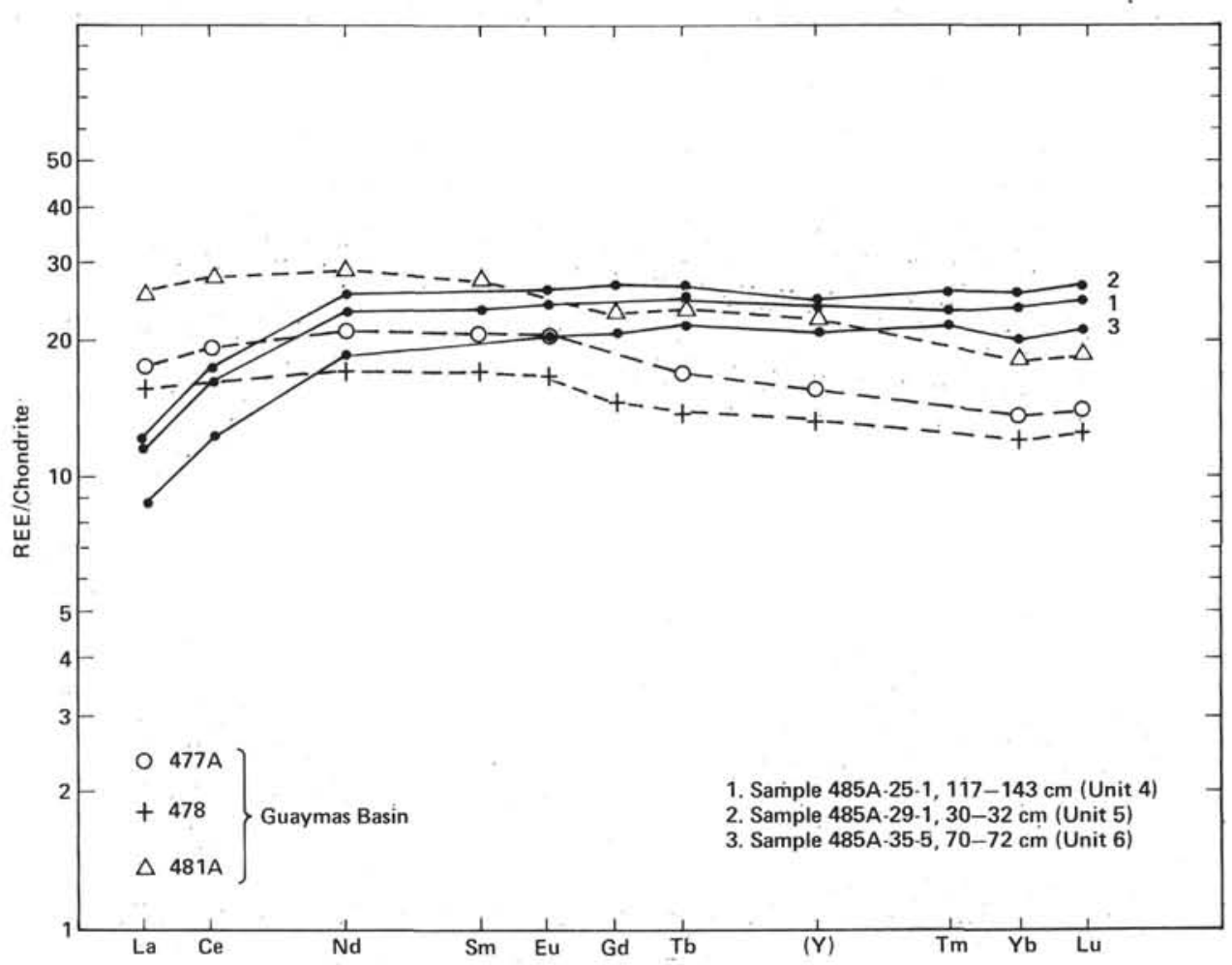

Figure 18. Chondrite-normalized rare earth element (REE) patterns for selected basalts, Site 485 . (Y values were determined by XRF, the remainder by INAA. REE patterns for Guaymas Basin samples are from Saunders et al. [in press]:) 
Table 10. Estimated HYG and more-HYG element ratios for sources of basalts recovered during Legs 64 and 65 .

\begin{tabular}{|c|c|c|c|c|c|c|}
\hline \multirow[b]{2}{*}{ Ratio } & \multicolumn{3}{|c|}{$\begin{array}{l}\text { Mouth of the Gulf of } \\
\text { California }\end{array}$} & \multicolumn{3}{|c|}{ Guaymas Basin } \\
\hline & Site 482 & Site 485 & Site 483 & Site 474 & Site 477 & Site 481 \\
\hline $\mathrm{La} / \mathrm{Ta}$ & 25 & 20 & 17 & 18 & 16 & 17 \\
\hline $\mathrm{Th} / \mathrm{Ta}$ & - & 1.3 & 1.2 & 1.3 & 1.0 & 1.6 \\
\hline $\mathrm{La} / \mathrm{Th}$ & 21 & 15 & 14 & 15 & 16 & 11 \\
\hline $\mathrm{Ba} / \mathrm{La}$ & 7.3 & 8.0 & 8.4 & 4.9 & 6.3 & $-b$ \\
\hline $\mathrm{Th} / \mathrm{Hf}$ & 0.04 & 0.06 & 0.06 & 0.11 & 0.11 & 0.18 \\
\hline $\mathrm{La}_{\mathrm{N}} / \mathrm{Sm}_{\mathrm{N}}$ & 0.5 & 0.5 & 0.5 & 0.7 & 0.8 & 0.9 \\
\hline $\mathrm{Ba} / \mathrm{Zr}$ & 0.22 & 0.24 & 0.25 & 0.24 & 0.27 & $-\mathrm{b}$ \\
\hline $\mathrm{Nb} / \mathrm{Zr}$ & 0.02 & 0.02 & 0.02 & 0.04 & 0.03 & 0.04 \\
\hline $\mathrm{LaN}_{\mathrm{N}} / \mathrm{Yb}_{\mathrm{N}}{ }^{\mathrm{a}}$ & 0.4 & 0.4 & 0.4 & 0.9 & 1.2 & 1.2 \\
\hline $\mathrm{Zr} / \mathrm{Y}^{\mathrm{a}}$ & 2.3 & 2.5 & 2.4 & 3.1 & 4.1 & 3.4 \\
\hline $\mathrm{Zr} / \mathrm{Ti}^{\mathrm{a}}$ & 0.008 & 0.009 & 0.008 & 0.011 & 0.012 & 0.012 \\
\hline
\end{tabular}

Note: $\mathrm{LaN}_{\mathrm{N}} / \mathrm{Sm}_{\mathrm{N}}=$ chondrite-normalized $\mathrm{La} / \mathrm{Sm}$ ratio.

a Because of probable pyroxene fractionation, the values shown are maximum values (see text for discussion). For the elements $\mathrm{La}, \mathrm{Ta}, \mathrm{Th}, \mathrm{Hf}, \mathrm{Zr}, \mathrm{Nb}$, and $\mathrm{Ba}, D$ is assumed to be zero for a $20 \%$ melt.

b The Ba contents of the Site 481 samples have been affected by secondary alteration processes.

Where known, the least incompatible element is the denominator in each ratio.

few kilometers of a continental margin. Clearly, from the information given in Table 10, there are no significant differences between the estimated incompatible element ratios of the basalt sources for Sites 482,483 , and 485. The high La/Ta ratio of the Site 482 source is probably due to analytical uncertainty, since only one Ta value was measured in the basalts from this site (see Table 3). The calculated Leg 65 basalt source has very low $\mathrm{Th} / \mathrm{Hf}, \mathrm{La} / \mathrm{Sm}, \mathrm{Ba} / \mathrm{Zr}$, and $\mathrm{Nb} / \mathrm{Zr}$ ratios and thus resembles the sources of depleted "N-type" MORB recovered from the MAR at $23^{\circ} \mathrm{N}$ (Bougault et al., 1978), the EPR (e.g., Sun et al., 1979) and the Galapagos Spreading Center (Mattey and Muir, 1980) (see Table 11). Notice that the estimated $\mathrm{Zr} / \mathrm{Y}, \mathrm{Zr} / \mathrm{Ti}$, and $\mathrm{La} / \mathrm{Yb}$ source ratios are very low. Indeed, they probably represent maximum values, since the presence of refractory pyroxene during melting would mean that these ratios would be enhanced in the primary melts (see Site 482 Discussion).

The basement samples from Site 474 (Units 474A-4 through 474A-8, Saunders et al., in press) also have low more-HYG/HYG element ratios and thus broadly resemble depleted N-type MORB. However, whereas the calculated more-HYG/more-HYG element ratios in the source resemble those calculated for the Leg 65 basalt source (Table 10), the Site 474 basalts have significantly higher $\mathrm{Th} / \mathrm{Hf}, \mathrm{La} / \mathrm{Sm}, \mathrm{La} / \mathrm{Yb}, \mathrm{Zr} / \mathrm{Ti}$, and $\mathrm{Zr} / \mathrm{Y}$ ratios. It is not possible to state with certainty whether these differences reflect differences in source composition or the effects of different conditions of partial melting, but it seems unlikely that the $\mathrm{Th} / \mathrm{Hf}$ and $\mathrm{La} / \mathrm{Sm}$ ratios would be changed significantly by varying the PTX conditions of melting-especially considering that in terms of the major elements, the Site 474 basalts are not very different from those recovered on Leg 65. In addition, if different PTX conditions were solely responsible for the different trace element chemistry of the Site 474 basalts, why do N-type MORB from elsewhere have such uniformly low $\mathrm{Th} / \mathrm{Hf}$ and $\mathrm{La} / \mathrm{Sm}$ ratios and what mechanism could produce these different PTX conditions of melting?
HYG/HYG element plots for the Site 474 basement samples are co-linear, which means either that these ratios reflect the ratios of the source (which by inference must be different from the source of the Leg 65 basalts) or that the primary mantle melt was formed in equilibrium with abundant refractory pyroxene.

It is worth mentioning that olivine-rich dolerite sills were also recovered by drilling at Site 474 . These dolerites are chemically different from any other samples recovered during Legs 64 and 65 in that they have very high $\mathrm{La} / \mathrm{Ta}$ ratios, high $\mathrm{MgO}, \mathrm{Ni}$, and $\mathrm{Cr}$ contents, and very low more-HYG/HYG element ratios (see Table 11, Unit 474A-2a). Paleontological evidence suggests that these sills postdate the basement lavas by at least 1.4 m.y., and Saunders et al. (in press) have proposed that they represent the fusion products of mantle which had been previously depleted during formation of the axis lavas. The occurrence of such depleted magmatic products implies unusual conditions of melting during the early stages of formation of the Gulf since they require either an off-axis heat source sufficiently intense to melt refractory mantle or a hydrous flux. To the author's knowledge no rocks of this composition have been previously recovered from the ocean floor, although it is interesting to note that similar rocks occur among the Upper Pillow Lavas of the Troodos Massif, Cyprus (Smewing and Potts, 1976). These authors also suggested that the Troodos ophiolite was formed in a back-arc basin, where hydrous fluids derived from adjacent subducted oceanic crust might facilitate the remelting process.

If it could be stated unequivocally that the mantle source feeding the EPR at the present time (Sites 485, 482 ) is chemically different from that which gave rise to the Site 474 basalts 3.2 m.y. ago, it would be possible to make a semiquantitative assessment of mantle evolution in the mouth of the Gulf of California. Although this is not possible, it is clear that the source has changed composition with time, becoming progressively more depleted in the more-HYG elements, and/or that the processes of magma generation have changed with time. Possible mechanisms for these changes will be considered after basalts from the mouth of the Gulf have been compared with those from the Guaymas Basin.

\section{Comparisons between the Gulf Mouth and the Guaymas Basin}

Drilling at three sites in the Guaymas Basin (Sites 477, 478 , and 481 ; Fig. 1) successfully recovered basalts, dolerites, and gabbros from very young oceanic crust. In the case of Sites 477 and 481 , the crust is probably less than $10,000 \mathrm{y}$. old. Because of the high sedimentation rates in the central part of the Gulf, the dominant igneous lithology consists of massive sill-like bodies, some up to 110 meters thick, with a marked absence of unequivocal flows (see Curray, Moore et al., in press). It is apparent from seismic reflection studies that Layers 1 and 2 of the normal oceanic sequence are completely intercalated. Although there has been considerable mobilization of sediment pore water in the vicinity of the intrusive bodies, and possible interaction between the pore water and the igneous material (cf. Einsele et al., 1980), detailed analyses of samples from the freshest 
Table 11. Representative analyses of mafic igneous rocks recovered on Leg 64 and ocean ridge basalts recovered from the Mid-Atlantic Ridge (MAR) and the Galapagos Spreading Center.

\begin{tabular}{|c|c|c|c|c|c|c|c|c|c|c|c|c|c|}
\hline \multirow[b]{3}{*}{ Unit } & \multirow{2}{*}{\multicolumn{3}{|c|}{$\begin{array}{c}\begin{array}{c}\text { Mouth of the } \\
\text { Gulf of California }\end{array} \\
\text { Site } 474 \\
\end{array}$}} & \multicolumn{6}{|c|}{ Guaymas Basin } & \multicolumn{2}{|c|}{ MAR, $23^{\circ} \mathrm{N}$} & \multicolumn{2}{|c|}{$\begin{array}{l}\text { Galapagos Spreading } \\
\text { Center }\end{array}$} \\
\hline & & & & \multicolumn{3}{|c|}{ Site 477} & \multirow{2}{*}{$\frac{\text { Site } 478}{478-4}$} & \multicolumn{2}{|c|}{ Site 481} & \multirow{2}{*}{$\frac{\text { Hole } 395}{\mathrm{~A} 2}$} & \multirow{2}{*}{$\frac{\text { Hole 395A }}{\text { P3 }}$} & \multirow{2}{*}{$\frac{\text { Hole } 424}{1}$} & \multirow{2}{*}{$\frac{\text { Hole } 425}{\mathrm{Cl}}$} \\
\hline & $474 \mathrm{~A}-2 \mathrm{a}$ & $474 \mathrm{~A}-7$ & $474 \mathrm{~A}-8$ & $477-2 b$ & $477-2 c$ & $477 \mathrm{~A}-2$ & & $481 \mathrm{~A}-1-8$ & $481-1-10$ & & & & \\
\hline \multicolumn{14}{|c|}{ Major Elements (wt.\%) } \\
\hline $\mathrm{SiO}_{2}$ & 44.5 & 48.3 & 48.7 & 49.8 & 48.3 & 49.0 & 48.8 & 50.1 & 50.1 & 49.3 & 49.5 & 50.28 & 50.44 \\
\hline $\mathrm{TiO}_{2}$ & 1.28 & 1.59 & 2.27 & 1.92 & 1.17 & 1.76 & 1.44 & 2.25 & 1.97 & 1.61 & 1.07 & 1.92 & 1.42 \\
\hline $\mathrm{Al}_{2} \mathrm{O}_{3}$ & 15.2 & 16.4 & 15.2 & 15.7 & 17.2 & 17.4 & 16.1 & 15.4 & 15.2 & 14.88 & 17.36 & 12.66 & 13.55 \\
\hline $\mathrm{tFe}_{2} \mathrm{O}_{3}$ & 10.77 & 10.61 & 11.66 & 10.25 & 9.33 & 9.66 & 9.59 & 10.94 & 10.89 & 11.95 & 8.67 & 15.21 & 12.92 \\
\hline $\mathrm{MnO}$ & 0.17 & 0.17 & 0.16 & 0.17 & 0.14 & 0.15 & 0.15 & 0.17 & 0.17 & 0.18 & 0.14 & 0.20 & 0.18 \\
\hline $\mathrm{MgO}$ & 14.87 & 7.50 & 7.25 & 6.95 & 9.20 & 7.23 & 8.80 & 6.82 & 7.05 & 8.5 & 7.8 & 6.66 & 7.03 \\
\hline $\mathrm{CaO}$ & 9.59 & 12.31 & 10.84 & 11.70 & 11.61 & 11.81 & 10.35 & 9.90 & 10.38 & 10.49 & 12.57 & 10.49 & 11.28 \\
\hline $\mathrm{Na}_{2} \mathrm{O}$ & 2.47 & 2.42 & 2.80 & 3.11 & 2.79 & 3.10 & 3.09 & 3.22 & 3.20 & 2.83 & 2.42 & 2.12 & 2.18 \\
\hline $\mathrm{K}_{2} \mathrm{O}$ & 0.00 & 0.11 & 0.23 & 0.20 & 0.18 & 0.25 & 0.29 & 0.51 & 0.37 & 0.09 & 0.12 & 0.04 & 0.02 \\
\hline $\mathrm{P}_{2} \mathrm{O}_{5}$ & 0.09 & 0.10 & 0.26 & 0.33 & 0.24 & 0.23 & 0.20 & 0.34 & 0.25 & 0.15 & 0.12 & 0.19 & 0.09 \\
\hline LÖI & 1.22 & - & 0.50 & - & 0.14 & - & - & - & 0.46 & 1.1 & 0.5 & 0.29 & 0.10 \\
\hline Total & 100.07 & 99.45 & 99.91 & 100.13 & 100.28 & 100.58 & 98.77 & 99.67 & 100.04 & 99.98 & 99.77 & 100.07 & 99.20 \\
\hline \multicolumn{14}{|c|}{ Trace Elements (ppm) } \\
\hline $\mathrm{Ni}$ & 522 & 110 & 87 & 48 & 118 & 66 & 81 & 87 & 80 & 190 & 156 & 49 & 48 \\
\hline $\mathrm{Cr}$ & 797 & 277 & 200 & 213 & 239 & 191 & 228 & 174 & 180 & 271 & 362 & - & - \\
\hline $\mathrm{Rb}$ & $<1$ & $<1$ & 1 & $<1$ & 1 & 1 & 3 & 5 & 4 & $<1.4$ & 2.2 & $<0.5$ & $<0.5$ \\
\hline $\mathrm{Sr}$ & 106 & 147 & 158 & 243 & 228 & 241 & 198 & 208 & 203 & 119 & 115 & 64 & 56 \\
\hline $\mathrm{Y}$ & 25 & 31 & 44 & 37 & 28 & 29 & 27 & 44 & 35 & - & - & - & - \\
\hline $\mathrm{Zr}$ & 70 & 101 & 147 & 150 & 107 & 123 & 106 & 171 & 123 & 126 & 69 & 116 & 68 \\
\hline $\mathrm{Ba}$ & 22 & 24 & 36 & 43 & 33 & 22 & 81 & 105 & 71 & - & - & - & - \\
\hline $\mathrm{La}$ & 1.1 & 4.9 & 6.6 & 7.1 & 5.3 & 5.6 & 4.5 & 8.4 & 6.1 & 3.2 & 2.2 & - & - \\
\hline $\mathrm{Ce}$ & 6.9 & 13.2 & 20.8 & 23.4 & 15.2 & 16.1 & 13.9 & 24.2 & 18.0 & - & - & 10.96 & 5.58 \\
\hline $\mathrm{Nd}$ & 9.2 & 11.4 & 11.2 & 19.1 & 12.5 & 12.9 & 11.0 & 18.3 & 15.8 & - & - & - & 6.80 \\
\hline $\mathrm{Sm}$ & 3.5 & 4.1 & 5.5 & - & 4.01 & 4.2 & 3.49 & 5.52 & - & - & - & - & - \\
\hline Eu & 1.40 & 1.4 & 2.1 & 2.19 & 1.41 & 1.56 & 1.30 & 1.94 & 1.65 & 1.33 & 1.01 & 1.40 & 1.14 \\
\hline $\mathrm{Tb}$ & 0.73 & 0.86 & 1.34 & 1.18 & 0.82 & 0.86 & 0.75 & 1.20 & 1.07 & 0.82 & 0.57 & 1.04 & 0.83 \\
\hline $\mathrm{Yb}$ & 2.68 & 3.37 & 4.93 & 4.31 & 2.67 & 2.99 & 2.67 & 4.24 & 3.48 & - & - & 4.79 & 3.66 \\
\hline Lu & 0.43 & 0.53 & 0.80 & 0.66 & 0.43 & 0.47 & 0.43 & 0.65 & 0.56 & - & - & - & - \\
\hline Th & 0.10 & 0.32 & 0.58 & 0.45 & 0.32 & 0.33 & 0.47 & 0.75 & 0.61 & 0.132 & 0.084 & - & - \\
\hline $\mathrm{Hf}$ & 2.49 & 2.84 & 3.80 & 5.53 & 2.57 & 3.01 & 2.55 & 4.24 & 3.40 & 2.71 & 1.76 & 2.78 & 2.02 \\
\hline Ta & $0.0 \mathrm{1}^{\mathrm{a}}$ & 0.25 & 0.47 & 0.46 & 0.31 & 0.33 & 0.27 & 0.44 & 0.41 & 0.183 & 0.111 & - & - \\
\hline \multicolumn{14}{|l|}{ Selected Ratios } \\
\hline $\mathrm{Ti} / \mathrm{Zr}$ & 110 & 94 & 93 & 77 & 66 & 86 & 81 & 79 & 96 & 77 & 93 & 99 & 125 \\
\hline $\mathrm{Sr} / \mathrm{Zr}$ & 1.5 & 1.5 & 1.1 & 1.6 & 2.1 & 2.0 & 1.9 & 1.2 & 1.7 & 0.9 & 1.7 & 0.6 & 0.8 \\
\hline $\mathrm{Y} / \mathrm{Zr}$ & 0.36 & 0.31 & 0.30 & 0.25 & 0.26 & 0.24 & 0.25 & 0.26 & 0.28 & - & - & - & - \\
\hline $\mathrm{La}_{\mathrm{N}} / \mathrm{Yb}_{\mathrm{N}}$ & 0.27 & 0.96 & 0.89 & 1.1 & 1.32 & 1.25 & 1.24 & 1.32 & 1.17 & $0.62^{\mathrm{a}}$ & $0.61^{\mathrm{a}}$ & $0.6^{\mathrm{a}}$ & $0.4^{\mathrm{a}}$ \\
\hline $\mathrm{La} / \mathrm{Sm}$ & 0.19 & 0.74 & 0.74 & $0.76^{\mathrm{a}}$ & 0.82 & 0.83 & 0.80 & 0.94 & $0.90^{\mathrm{a}}$ & - & - & $0.6^{\mathrm{a}}$ & $0.4^{\mathrm{a}}$ \\
\hline $\mathrm{Th} / \mathrm{Hf}$ & 0.04 & 0.11 & 0.15 & 0.10 & 0.12 & 0.11 & 0.18 & 0.18 & 0.18 & 0.05 & 0.05 & - & - \\
\hline $\mathrm{La} / \mathrm{Ta}$ & 110 & 20 & 14 & 15 & 17 & 17 & 18 & 19 & 15 & 17 & 20 & - & - \\
\hline
\end{tabular}

Note: Unit 474A-2a: Sample 474A-42-1, 6-8 cm; Unit 474A-7: Sample 474A-48-1, 101-103 cm; Unit 474-8: Sample 474A-50-4, 1-4 cm; Unit 477-2b: Sample 477-9-1, 57-59 cm; Unit 477-2c: Sample 477-11-2, 61-63 cm; Unit 477A-2: Sample 477A-2-2, 64-68 cm; Unit 478-4: Sample 478-44-1, 110-112 cm; Unit 481A-1-8: Sample 481A-15-3, 27-29 cm; Unit 481A-1-10: Sample 481A-15-3, 69-71 cm. (Analyses for Sites 474, 477, 478, and 481 from Saunders et al., (in press). MAR, $23^{\circ} \mathrm{N}$, Unit A2: Sample 395-11-2, 62-64 cm (aphyric basalt); Unit P3: Sample 395A-16-1, 100-104 cm (plagioclase-olivine-phyric basalt) (Bougault et al., 1978). Galapagos Spreading Center Unit 1: Sample 424-5-4, Piece 1; Unit C1: 425-7-1, Piece 7 (Mattey and Muir, 1980). tFe $2 \mathrm{O}_{3}=$ total iron as $\mathrm{Fe}_{2} \mathrm{O}_{3} ; \mathrm{LOI}=$ loss on ignition. $\mathrm{CeN} / \mathrm{Yb} \mathrm{N}=$ chondrite-normalized $\mathrm{Ce} / \mathrm{Yb}$ ratio.

a Interpolated values.

parts of the igneous units have shown that the primary abundances of only the elements $\mathrm{K}, \mathrm{Rb}, \mathrm{Cs}$, and to a lesser extent Ba have been significantly affected (Saunders et al., in press). $\mathrm{Sr}$, which shows a tight clustering of values when plotted against $\mathrm{Zr}$ (see Fig. 8), appears to behave in a coherent fashion and its abundance has apparently not been affected by the hydrothermal processes operating in the Guaymas Basin.

Analyses of mafic rocks recovered from the Guaymas Basin are included in Table 11. In general terms, they all exhibit a low content of the immobile more-HYG elements (for example, $\mathrm{La}_{N} / \mathrm{Sm}_{\mathrm{N}}<1$ but $\mathrm{La}_{\mathrm{N}} / \mathrm{Yb}_{\mathrm{N}}>1$; Figs. 13 and 18 ), and in several respects they broadly resemble the basement samples recovered at Site 474 .
However, in detail, the Guaymas Basin samples have higher $\mathrm{Th} / \mathrm{Hf}, \mathrm{Zr} / \mathrm{Y}, \mathrm{La} / \mathrm{Yb}$, and $\mathrm{Zr} / \mathrm{Ti}$ ratios than the Site 474 and Leg 65 basalts. Calculated incompatible element ratios for the source of the Guaymas Basin samples are shown in Table 10. Again, the more-HYG/more-HYG element ratios remain essentially constant and the high $\mathrm{La} / \mathrm{Ta}$ ratios are typical of depleted N-type MORB. The differences in the more-HYG/HYG and HYG/HYG element ratios shown for the Leg 65 and Guaymas Basin sources may be real or artifacts of the calculation due to the possible effects of partial melting. As with the Site 474 samples, however, the HYG-HYG element trends are co-linear, implying either that the ratios truly represent the source ratios or that they represent the ratio of a 
primary melt which was produced in equilibrium with abundant refractory pyroxene.

However, there is one piece of evidence which strongly suggests that the mantle source beneath the Guaymas Basin is indeed different from that of the Site 474 and Leg 65 basalts: the high $\mathrm{Sr}$ content of the Site 477, 478, and 481 samples. As outlined above, it is felt that the $\mathrm{Sr}$ content of the Guaymas Basin samples is primary. A portion of the $\mathrm{Sr}$ in the Guaymas Basin mafic rocks may be due to the presence of some plagioclase phenocrysts of cumulus origin, but several sparsely plagioclase-phyric units also have high $\mathrm{Sr}$ contents. Thus, the high $\mathrm{Sr}$ values imply that the mantle source beneath the Guaymas Basin has relatively high $\mathrm{Sr} / \mathrm{HYG}$ element ratios. Note that this feature is common to samples from all three sites and even to the basalts from Tortuga Island (Batiza et al., 1979).

The chemical differences between the Leg 65 basalts and the Site 474 basalts on one hand, and the similar, but more pronounced differences between the Leg 65 basalts and the Guaymas Basin samples on the other, lead to the conclusion that the spreading center in the Gulf of California has tapped successive mantle sources and/or that the conditions of magma generation have changed. It now remains necessary to postulate an explanation for these differences in magma compositionare they a function of different conditions of partial melting or of mantle heterogeneity?

\section{Magma Variability in the Gulf of California}

There is now a general consensus among igneous petrologists that the upper mantle is chemically heterogeneous, although there is still little agreement on the actual scale, age, or cause of the observed and inferred variations in mantle composition. Detailed trace element and isotope studies of basaltic rocks-particularly those from the oceanic regions, where crustal contamination is minimal-have provided perhaps the most important information on mantle heterogeneity. Thus, recent work on basalts from the North Atlantic has shown that two chemically distinct magma types are being produced at the Mid-Atlantic Ridge: normal, depleted, mid-ocean ridge basalts (N-type MORB: Sun et al., 1979), which have very low more-HYG/HYG element ratios (e.g., $\mathrm{Th} / \mathrm{Hf}<0.1 ; \mathrm{Rb} / \mathrm{Sr}<0.01$ ) (Schilling, 1971; Frey et al., 1974; Wood, Joron, Treuil, et al., 1979; Wood, Tarney, Varet, et al., 1979; Tarney et al., 1980), low ${ }^{87} \mathrm{Sr} / 86 \mathrm{Sr}$ ratios $(0.7023-0.7027$ : Hart, 1971), and high ${ }^{143} \mathrm{Nd} /{ }^{144} \mathrm{Nd}$ ratios $(0.5131-0.5133$ : De Paulo and Wasserburg, 1976; O'Nions et al., 1977); and enriched, or E-type MORB ("plume" or 'P-type”' of Sun et al., 1979) which are typically erupted on ridge segments (and ocean islands) with positive heat flow and depth anomalies and which have high more-HYG/HYG element ratios (e.g., Th/Hf $>0.2 ; \mathrm{Rb} / \mathrm{Sr} \sim 0.04$ ) (Hart et al., 1973; Wood, Joron Treuil, et al., 1979; Wood, Tarney, Varet, et al., 1979; Tarney et al., 1979, 1980). In addition, the E-type MORB have higher ${ }^{87} \mathrm{Sr} /{ }^{86} \mathrm{Sr}$ ratios (0.7027-0.7035: White et al., 1976) and lower ${ }^{143} \mathrm{Nd} /$ ${ }^{144} \mathrm{Nd}$ ratios $(<0.5131$ : O'Nions et al., 1977) than do the $\mathrm{N}$-type MORB. The $\mathrm{E}$ and $\mathrm{N}$-type MORB tend to vary gradationally along the mid-ocean ridge producing transitional (or T-type) basalts at locations between the two extremes.

The differences in chemistry between the E- and $\mathrm{N}$-type MORB can be adequately explained only by invoking mantle heterogeneity; not only are the initial isotopic ratios of the two basalt types considerably different, but so are their more-HYG/more-HYG element ratios. Thus, the $\mathrm{La} / \mathrm{Ta}$ ratio for E-type MORB is usually about 8 , whereas this ratio is typically about 18 for N-type MORB (see discussion by Bougault et al., 1980). Even in the absence of isotope data, all of the Leg 65 basalts are typical of N-type MORB, and in general terms the Leg 64 samples possess many of the characteristics of N-type MORB, although the moderate $\mathrm{Th} / \mathrm{Hf}$ ratios in the Guaymas Basin samples are similar to those in T-type MORB. (The La/Ta ratios are too high, and the $\mathrm{La} / \mathrm{Sm}$ ratios too low, however, for the Guaymas Basin samples to be classified as T-type MORB).

Unfortunately, very little high-precision data are available for basalts from the EPR for comparison with the Leg 65 and 64 data. This is a critical omission because until such data are available, it is not possible to be certain that the variations observed between the mouth of the Gulf and the Guaymas Basin do not occur along "normal" sections of the EPR. The available data do indicate, however, that the basalts recovered from truly "oceanic" sections of the EPR (i.e., the greater portion of its length) are indeed strongly depleted in the more-HYG elements (Sun et al., 1979; Mattey and Muir, 1980) and closely resemble the basalts recovered during Leg 65.

Assuming, therefore, that most of the EPR is erupting strongly depleted $\mathrm{N}$-type MORB, the high $\mathrm{La} / \mathrm{Sm}, \mathrm{Sr} / \mathrm{Zr}$, $\mathrm{Zr} / \mathrm{Ti}, \mathrm{Zr} / \mathrm{Y}$, and $\mathrm{Th} / \mathrm{Hf}$ ratios of the Guaymas Basin samples are likely to be a function of their having formed in an ensialic basin. As stated previously, the Gulf of California is not a true back-arc basin; for example, it is not directly associated with a contemporaneous subduction zone. Nevertheless, the Gulf did open within continental crust which until Tertiary time was bounded to the west by a subduction zone, as demonstrated by the presence of abundant calc-alkaline plutonic and volcanic products throughout southern California (Gastil et al., 1975; Dickinson and Snyder, 1979). It is not unreasonable to assume, therefore, that a portion of the mantle beneath the Gulf region was intimately associated with subduction-related processes and may possess some chemical features characteristic of calc-alkaline magmatism (e.g., high LIL/HFS element ratios (Th/Hf, for example) and high LIL-element abundances (e.g., $\mathrm{Sr}, \mathrm{R}, \mathrm{K}, \mathrm{Ba}, \mathrm{Th})$ ). The chemistry of the Leg 64 samples necessitates that this subcontinental calc-alkaline component be very small, which concurs with Dickinson and Synder's (1979) model whereby the present Gulf region is underlain by a no-slab window and, by inference, " $\mathrm{Pa}$ cific-type" (depleted) mantle. It is also reasonable to assume that the subcontinental component would be more important, both during the earliest period of basin opening (Site 474) before normal, rapid EPR-type spreading was established, and in the central (and northern?) parts 
of the Gulf, where the total length of the spreading ridge (and the size of the convection cells?) is relatively small.

These observations are not without precedent. Recent studies of ensialic back-arc basins in South America (the "rocas verdes" ophiolite complexes of southern Chile) and in the Scotia Arc (Bransfield Strait, Antarctica) have shown that magmas produced during the initial stages of back-arc basin formation may possess a complex "hybrid" chemistry, intermediate in character between ocean ridge and calc-alkaline basalts.

The "rocas verdes" complex stretches northward from near Cape Horn to about $49^{\circ} \mathrm{S}$ and represents a narrow marginal basin which opened in the late Jurassic and which had closed again by the mid-Cretaceous (Dalziel et al., 1974). Field evidence suggests that the basin was widest in the south, in the vicinity of Tortuga Island (Chile), and narrowed progressively toward the north at Sarmiento. It is possible that it existed as a series of enechelon basins, perhaps not unlike those in the Gulf of California (see Dalziel, 1981). Geochemical studies of basalts from the complex (Saunders et al., 1979; Stern, $1979,1980)$ show that those collected in the north display relatively enriched geochemical characteristics (e.g., $\mathrm{Ce}_{\mathrm{N}}$ / $\mathrm{Yb}_{\mathrm{N}} \sim 2$ ) whereas those collected in the south, near Tortuga where the basin was widest, display depleted geochemical features typical of N-type MORB. The freshest samples from Sarmiento show enrichment in $\mathrm{K}, \mathrm{Rb}, \mathrm{Ba}$, and to a lesser extent, $\mathrm{Sr}$, relative to $\mathrm{N}$-type MORB, but retain the low $\mathrm{Nb} / \mathrm{Zr}$ and high $\mathrm{La} / \mathrm{Nb}$ ratios typical of normal mid-ocean ridge basalts. The Tortuga samples, however, do not exhibit LIL-element enrichment, although the basalts from a series of dikes flanking the Tortuga complex display "enriched" geochemical features similar to those within the Sarmiento complex.

Stern $(1979,1980)$ considered that much of the difference in basalt chemistry between the Sarmiento and Tortuga ophiolites could be explained in terms of the dynamic melting model of Langmuir et al. (1977). Thus the first stage melts generated during the initial opening of the basin had a relatively "enriched" geochemical composition consistent with limited partial melting of an undepleted mantle source. However the later, second stage melts, erupted as a consequence of continued diapirism, had correspondingly "depleted" trace element compositions; indeed some of the later dykes cutting the complex are highly magnesian (Elthon, 1979) (cf. Site 474 off-axis sills). This model does not, however, adequately explain why only the LIL-elements, and not the HFS elements, are enriched in the Sarmiento Complex. Saunders et al. (1979) and Tarney et al. (1981) suggested that variations in mantle-source composition may be a more viable method of producing the observed differences in basalt chemistry. According to this explanation, the upper mantle source regions beneath southern Chile were contaminated and enriched in LIL-elements during earlier phases of calc-alkaline magmatism. Thus, subcontinental mantle with LIL-element-enriched characteristics (cf. discussion in Saunders et al., 1980b) might affect the products of basaltic volcanism during the early stages of back-arc rifting, but not during the later stages of rifting as the subcontinental lithosphere was pulled apart and separated.

It is important, however, not to overstate the analogy between the Gulf of California and the "rocas verdes.", Although both basins formed in regions intimately associated with subduction-zone processes, no subduction zone presently underlies the Gulf-the tectonics of the region are dominantly strike-slip. Nevertheless, the occurrence of Mesozoic and Tertiary calc-alkaline rocks throughout southern California does indicate the potential involvement of LIL-element enriched mantle during the formation of the marginal and central Gulf magmas. As in the "rocas verdes" model, it is suggested that the earliest Gulf of California basalts were derived from a source containing a subcontinental mantle component. This would also hold true for magmas produced in the central part of the Gulf. However, as rifting proceeded, the subcontinental component would diminish until only $\mathrm{N}$-type mid-ocean ridge basalts were being erupted.

The mantle heterogeneity model is perhaps the simplest way of explaining the chemical variations in the Gulf of California magmas. Several of these variations could perhaps be produced by changing conditions of magma genesis but this immediately raises the question, why should such changes occur? It is important to stress that the degree of mantle heterogeneity is small and significantly less than that observed in other basins (e.g., the "rocas verdes" complex or Bransfield Strait) which were or are directly associated with active subduction zones. In intraoceanic back-arc basins, the involvement of a slab-derived component may be small (e.g., the Scotia Sea: Saunders and Tarney, 1979) or chemically undetectable (e.g. the Shikoku Basin: Marsh et al., 1980), depending on the evolutionary stage of the basin and its underlying mantle. The Gulf of California is in a similar evolutionary stage: only in the mouth, where seafloor spreading is really underway, do we see uncontaminated N-type MORB being generated.

\section{ACKNOWLEDGMENTS}

I would like to thank the Leg 65 shipboard party for supplying fresh basalt samples for this study and for informative discussions concerning the results of the cruise. G. L. Hendry assisted in the XRF analysis at Birmingham and Giselle F. Marriner provided essential help during the INA analysis at Bedford College. I am also grateful to N. Sinclair-Jones who drafted the diagrams and to Sheila Bishop who typed the manuscript. Part of this research was carried out while on a research fellowship at Birmingham; the financial support of the Natural Environment Research Council, U.K., is gratefully acknowledged.

The manuscript was reviewed and improved by Professor John Tarney and Dr. M. Ann Morrison.

\section{REFERENCES}

Arth, J. G., and Hanson, G. N., 1975. Geochemistry and origin of the early Precambrian crust of northeastern Minnesota. Geochim. Cosmochim. Acta, 39:325-362.

Batiza, R., Futa, K., and Hedge, C. E., 1979. Trace element and strontium isotope characteristics of volcanic rocks from Isla Tortuga: A young seamount in the Gulf of California. Earth Planet. Sci. Lett., 43:269-278.

Bennett, H., and Oliver, G. J., 1976. Development of fluxes for the analysis of ceramic materials by X-ray fluorescence spectrometry. Analyst, 101:803-807. 
Bougault, H., Joron, J.-L., and Treuil, M., 1980. The primordial chondritic nature and large-scale heterogeneities in the mantle: Evidence from high and low partition coefficient elements in ocean basalts. Philos. Trans. R. Soc. London, A297:203-213.

Bougault, H., Treuil, M., and Joron, J.-L., 1978. Trace elements in basalts from $22^{\circ} \mathrm{N}$ and $36^{\circ} \mathrm{N}$ in the Atlantic Ocean: Fractional crystallization, partial melting and heterogeneity of the upper mantle. In Melson, W. G., Rabinowitz, P. D., et al., Init. Repts. DSDP, 45: Washington (U.S. Govt. Printing Office), 493-506.

Bougault, H., and Treuil, 1980. Mid-Atlantic Ridge: Zero-age geochemical variations between Azores and $22^{\circ} \mathrm{N}$. Nature, 286: 209-212.

Curray, J. R., and Moore, D. G., et al., in press. Init. Repts. DSDP, 64: Washington (U.S. Govt. Printing Office).

Dalziel, 1. W. D., 1981. Back-arc spreading in the southern Andes: A review and critical reappraisal. Philos. Trans. R. Soc. London, A300:319-335.

Dalziel, I. W. D., de Wit, M. J., and Palmer, K. F., 1974. Fossil marginal basin in the southern Andes. Nature, 250:291-294.

De Paulo, D. J., and Wasserburg, G. J., 1976. Nd isotopic variations and petrogenetic models. Geophys. Res. Lett., 3:249-252.

Dickinson, W. R., and Snyder, W. S., 1979. Geometry of subducted slabs related to San Andreas transform. J. Geol., 87:609-627.

Dungan, M. A., and Rhodes, J. M., 1978. Residual glasses and melt inclusions in basalts from DSDP Legs 45 and 46: Evidence for magma mixing. Contrib. Mineral. Petrol., 67:417-431.

Einsele, G., Gieskes, J. M., Curray, J. R., et al., 1980. Intrusion of basaltic sills into highly porous sediments, and resulting hydrothermal activity. Nature, 283:441-445.

Elthon, D., 1979. High magnesia liquids as the parental magma for ocean floor basalts. Nature, 278:514-518.

Frey, F. A., Bryan, W. B., and Thompson, G., 1974. Atlantic Ocean Floor: Geochemistry and petrology of basalts from Legs 2 and 3 of the Deep Sea Drilling Project. J. Geophys. Res., 79:5507-5527.

Gastil, R. G., Phillips, R. P., and Allison, E. C., 1975. Reconnaissance geology of the State of Baja California. Mem. Geol. Soc. Am. 140 .

Hart, S. R., 1971. K, Rb, Cs, $\mathrm{Sr}$ and $\mathrm{Ba}$ contents and $\mathrm{Sr}$ isotope ratios of ocean floor basalts. Philos. Trans. R. Soc. London, A268: 573-587.

1976. LIL-element geochemistry, Leg 34 basalts. In Hart, S. R., Yeats, R. S., et al., Init. Repts. DSDP, 34: Washington (U.S. Govt. Printing Office), 215-226.

Hart, S. R., and Davis, K. E., 1978. Nickel partitioning between olivine and silicate melt. Earth Planet. Sci. Lett., 40:203-219.

Hart, S. R., Erlank, A. J., and Kable, E. J. D., 1974. Sea floor basalt alteration: Some chemical and strontium isotopic effects. Contrib. Mineral. Petrol., 44:219-230.

Hart, S. R., Schilling, J.-G., and Powell, J. L., 1973. Basalts from Iceland and along the Reykjanes Ridge: Sr-isotope geochemistry. Nature, 246:104-107.

Harvey, P. K., Taylor, D. M., Hendry, G. L., et al., 1973. An accurate fusion method for the analysis of rocks and chemically related materials by X-ray fluorescence spectrometry. X-Ray Spectrom., 2:33-44.

Hendry, G. L., 1975. X-ray fluorescence. In Nicol, A. W. (Ed.), Physicochemical Methods of Mineral Analysis: New York (Plenum Press), pp. 87-152.

Karig, D. E., and Jensky, W., 1972. The proto-Gulf of California. Earth Planet. Sci. Lett., 17:169-174.

Kay, R. W., Hubbard, N. J., and Gast, P. W., 1970. Chemical characteristics and origin of oceanic ridge volcanic rocks. J. Geophys. Res., 75:1585-1613.

Langmuir, C. H., Bender, J. F., Bence, et al., 1977. Petrogenesis of basalts from the FAMOUS area: Mid-Atlantic Ridge. Earth Planet. Sci. Lett., 36:133-156.

Leeman, W. P., 1973. Petrogenesis of McKinney (Snake River) olivine tholeiite in the light of rare-earth element and $\mathrm{Cr} / \mathrm{Ni}$ distributions. Geol. Soc. Am. Bull., 87:1582-1586.

Ludden, J. A., and Thompson, G., 1979. An evaluation of the behaviour of the rare earth elements during the weathering of sea floor basalt. Earth Planet. Sci. Lett., 43:85-92.
Luyendyk, B. P., Cann, J. R., et al., 1979. Init. Repts. DSDP, 49: Washington (U.S. Govt. Printing Office).

McCallum, I. S., and Charette, M. P., 1978. Zr and Nb partition coefficients: implications for the generation of mare basalts, KREEP and sea floor basalts. Geochim. Cosmochim. Acta, 42:859-869.

Marsh, N. G., Saunders, A. D., Tarney, J., 1980. Geochemistry of basalts from the Shikoku and Daito Basins, Deep Sea Drilling Project Leg 58. In Klein, G. De V., Kobayashi, K., et al., Init. Repts. DSDP, 58: Washington (U.S. Govt. Printing Office), 805-842.

Mattey, D. P., and Muir, I. D., 1980. The geochemistry and mineralogy of basalts from the Galapagos Spreading Center, IPOD Leg 54. In Rosendahl, B. R., Hekinian, R., et al., Init. Repts. DSDP, 54: Washington (U.S. Govt. Printing Office), 755-772.

Mitchell, W. S., and Aumento, F., 1977. Uranium in oceanic rocks: Deep Sea Drilling Project Leg 37. Can. J. Earth Sci., 14:794-808.

O'Hara, M. J., 1977. Geochemical evolution during fractional crystallisation of a periodically refilled magma chamber. Nature, 266: 503-507.

O'Nions, R. K., Hamilton, P. J., and Evensen, N. M., 1977. Variations in ${ }^{143} \mathrm{Nd} /{ }^{144} \mathrm{Nd}$ and ${ }^{87} \mathrm{Sr} /{ }^{86} \mathrm{Sr}$ ratios in oceanic basalts. Earth Planet. Sci. Lett., 34:13-22.

Pankhurst, R. J., 1977. Open system crystal fractionation and incompatible element variation in basalts. Nature, 268:36-38.

Pearce, J. A., and Norry, M. J., 1979. Petrogenetic implications of $\mathrm{Ti}, \mathrm{Zr}, \mathrm{Y}$ and $\mathrm{Nb}$ variations in volcanic rocks. Contrib. Mineral. Petrol., 69:33-47.

Saunders, A. D., Fornari, D. J., Joron, J.-L., et al., in press. Geochemistry of basic igneous rocks recovered from the Gulf of California: Deep Sea Drilling Project Leg 64. In Curray, J. R., Moore, D. G., et al. Init. Repts. DSDP, 64: Washington (U.S. Govt. Printing Office)

Saunders, A. D, and Tarney, J., 1979. The geochemistry of basalts from a back-arc spreading centre in the East Scotia Sea. Geochim. Cosmochim. Acta, 43:555-572.

Saunders, A. D., Tarney, J., Marsh, N. G., et al., 1980. Ophiolites as ocean crust or marginal basin crust: A geochemical approach. Proc. Int. Ophiolite Conf., Nicosia, Cyprus, pp. 193-204.

Saunders, A. D., Tarney, J., Stern, C. R., et al., 1979. Geochemistry of Mesozoic marginal basin floor igneous rocks from southern Chile. Geol. Soc. Am. Bull., 90:237-258.

Saunders, A. D., Tarney, J., and Weaver, S. D., 1980. Transverse geochemical variations across the Antarctic Peninsula: Implications for the genesis of calc-alkaline magmas. Earth Planet. Sci. Lett., 46:344-360.

Schilling, J.-G., 1971. Sea-floor evolution: Rare-earth evidence. Philos. Trans. R. Soc. London, A268:663-706.

Schnetzler, C. C., and Philpotts, J. A., 1970. Partition coefficients of rare-earth elements and barium between igneous matrix materials and rock-forming mineral phenocrysts-II. Geochim. Cosmochim. Acta, 34:331-340.

Smewing, J. D., and Potts, P. J., 1976. Rare earth abundances in basalts and metabasalts from the Troodos Massif, Cyprus. Contrib. Mineral. Petrol., 57:245-258.

Stern, C. R., 1979. Open and closed system igneous fractionation within two Chilean ophiolites and the tectonic implication. Contrib. Mineral. Petrol., 68:243-258.

1980. Geochemistry of Chilean ophiolites: Evidence for the compositional evolution of the mantle source of back-arc basin basalts. J. Geophys. Res., 85:955-966.

Sun, S.-S., Nesbitt, R. W., and Sharaskin, A. Ya., 1979. Geochemical characteristics of mid-ocean ridge basalts. Earth Planet. Sci. Lett., 44:119-138.

Tarney, J., Saunders, A. D., Mattey, D. P., et al., 1981. Geochemical aspects of back-arc spreading in the Scotia Sea and west Pacific. Philos. Trans. R. Soc. London, A300:263-285.

Tarney, J., Saunders, A. D., Weaver, S. D., et al., 1979. Minorelement geochemistry of basalts from Leg 49, North Atlantic Ocean. In Luyendyk, B. P., Cann, J. R., et al., Init. Repts. DSDP, 49: Washington (U.S. Govt, Printing Office), 657-691. 
Tarney, J., Wood, D. A., Saunders, A. D., et al., 1980. Nature of mantle heterogeneity in the North Atlantic: Evidence from Deep Sea Drilling. Philos. Trans. R. Soc. London, A297:179-202.

Thompson, G., Bryan, W. B., Frey, F. A., et al., 1976. Petrology and geochemistry of basalts from DSDP Leg 34, Nazca Plate. In Hart, S. R., Yeats, R. S., et al., Init. Repts. DSDP, 34: Washington (U.S. Govt. Printing Office), 215-226.

Weaver, S. D., Saunders, A. D., Pankhurst, R. J., et al., 1979. A geochemical study of magmatism associated with the initial stages of back-arc spreading: The Quaternary volcanics of Bransfield
Strait, from South Shetland Islands. Contrib. Mineral. Petrol., 68:151-169.

White, W. R., Schilling, J.-G., and Hart, S. R., 1976. Evidence for the Azores mantle plume from strontium isotope geochemistry of the central North Atlantic. Nature, 263:659-663.

Wood, D. A., Joron, J.-L., Treuil, M., et al., 1979a. Elemental and $\mathrm{Sr}$-isotope variations in basic lavas from Iceland and the surrounding ocean floor. Contrib. Mineral. Petrol., 70:319-339.

Wood, D. A., Tarney, J., Varet, J., et al., 1979b. Geochemistry of basalts drilled in the North Atlantic by IPOD Leg 49: Implications for mantle heterogeneity. Earth Planet. Sci. Lett., 42:77-97. 